\title{
صلابة الشخصية و علاقتها بأساليب مواجهة الضغوط النفسية لاى المراهقين المكفوفين
}

$$
\begin{aligned}
& \text { إعداد } \\
& \text { د. سهام عبدالغفار عليوة } \\
& \text { مدرس الصحة النفسية - كلية التربية } \\
& \text { جامعه كفر الثيخ }
\end{aligned}
$$

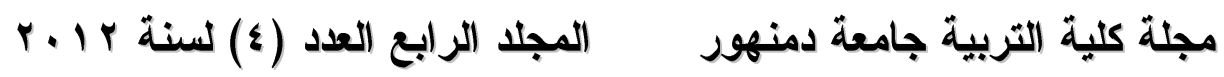


صلابة الثخصية وعلافتها بأساليب مو اجهة الضغوط النفسية لاى المراهقين المكفوفين د. سهام عبد الغفور 
صلابة الشخصية و علاقتها بأساليب مو اجهة الضغوط النفسية لدى المر اهقين المكفوفين

د.سهام عبدالغفار عليوة

المقدمة

يحتاج الكفيف إلــى التقــدير و المحبــة و الأمــن و الانتمـــاء و الاســتقلال

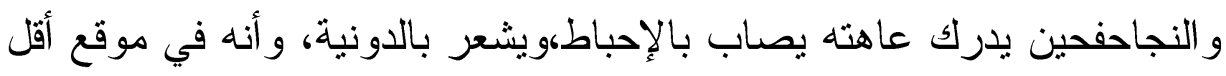

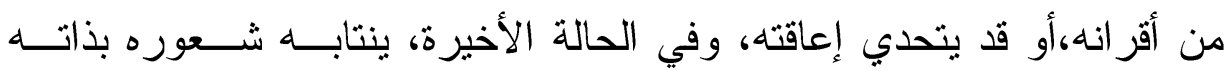

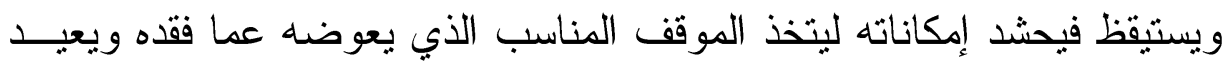

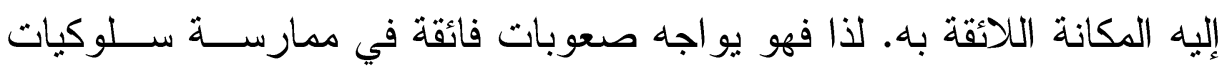

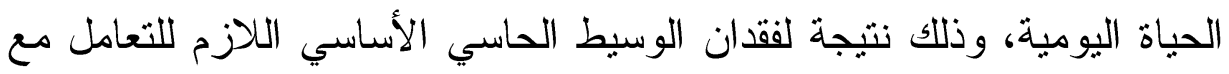
المثير ات البصرية.

فققد حاسة البصر يؤثر في السلوك الاجتماعي للفرد تأثيراً سلبياً،حيث ينشأ

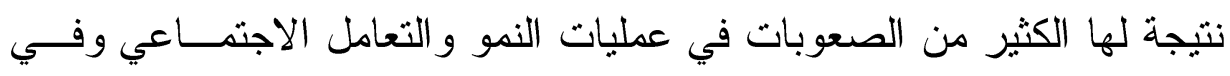

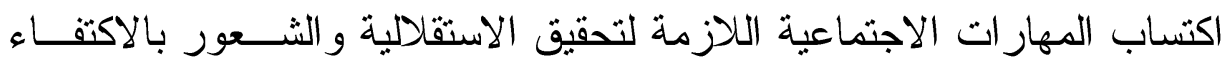

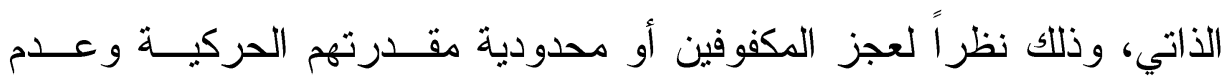

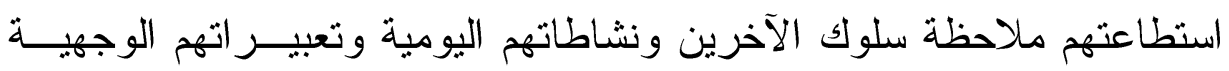

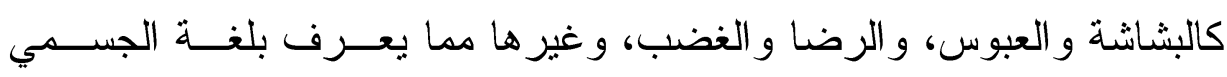

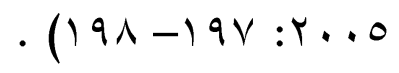
أثثتث العديد من الدراسات و البحوث السابقة أن المكفوفين يتصفون بالعديد

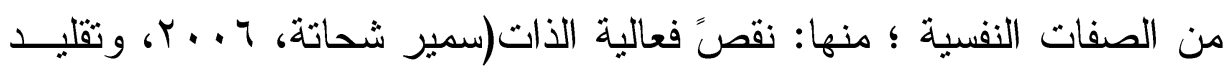
هذه السلوكيات، أو محاكاتها بصرياً و التعلم منها (عبدالمطلب القريط) كما أنها لفح

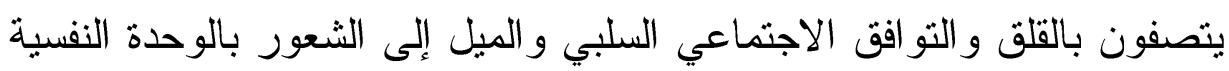

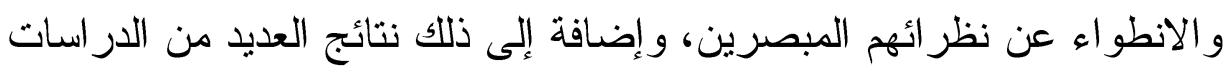

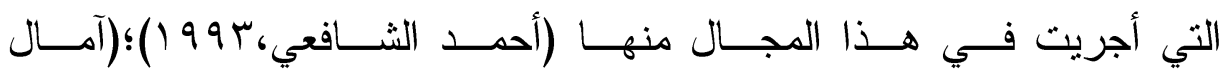

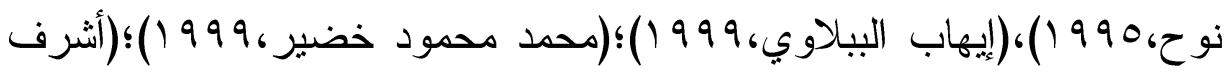

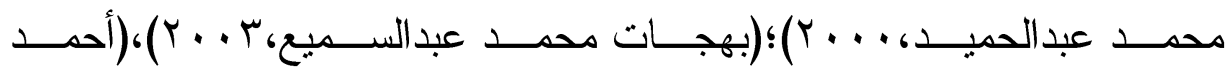




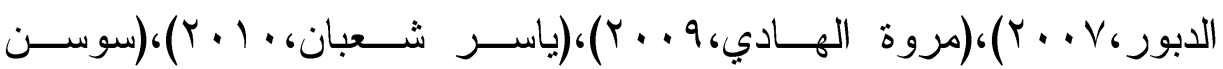

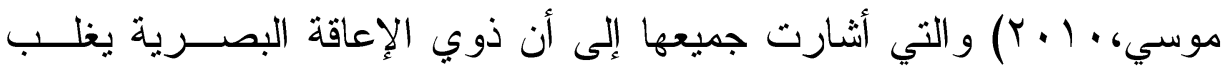

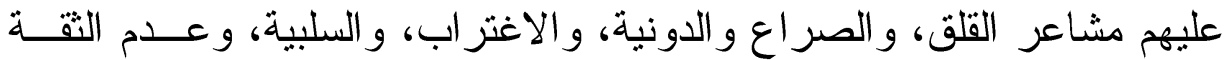
بالنفس، واختلاف صورة الجسم، والانطواء، وان هذه الفئة أكثـر اســتخداما

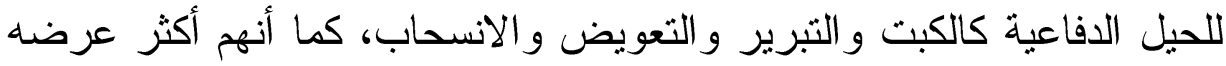

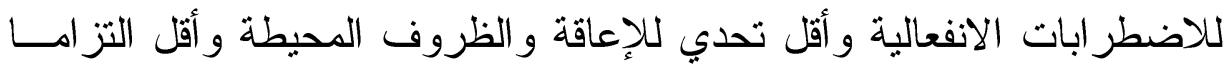

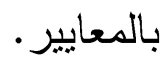

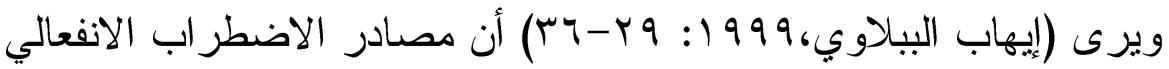

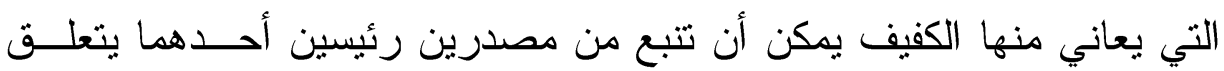

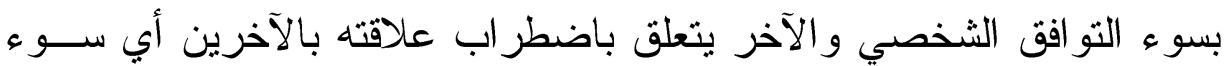

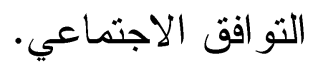
و عن مشاعر الكفيف إزاء نظرة الآخرين تجاهه يري (عبدالسلام عبدالغفار

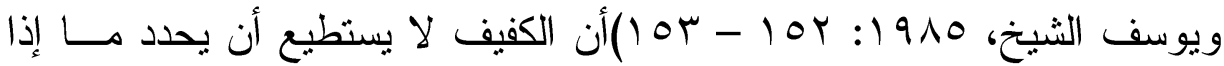

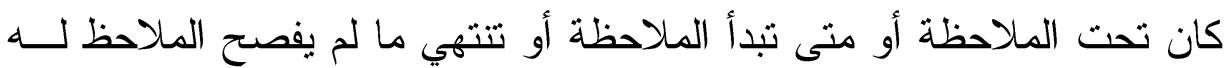
عن نفسه بطريقة غير بصرية و هذا الخوف في حد ذاته يُحدث شيئًا من التوتر

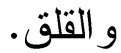
أما أساليب مواجهة الضغوط النفسية فهي تعتبر مدخلاً للحد من العديد من

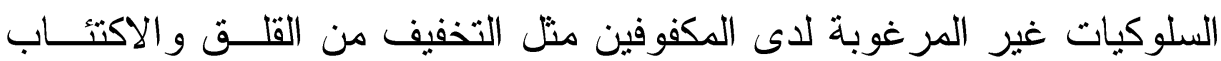

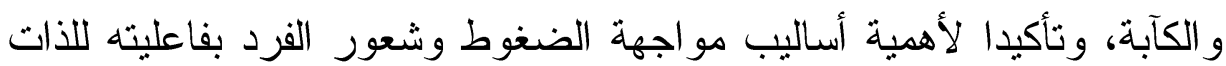
الإيجابية، فعندما يفشل الثخـص صن عن أن يشعر بصلاحيته، فإن المجتمع يعجز

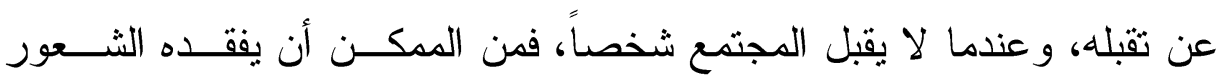
بصلاحيته.

و هذا ما يؤكده (جابـر عبدالحميد، 9 (91) في أن الذين يتمتعون بأســاليب عالية لمو اجهة الضغوط النفسية يعتقدون أنهم يقدرون على عمل شئ لتغييــر

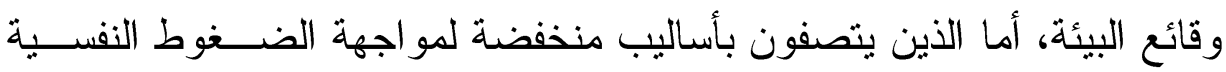


فإنهم ينظرون إلى أنفسهم باعتبار هم عاجزين عن إحداث ســلوك لــه أثـاره ونتائجه.

فأساليب مواجهة الضــغوط النفسـية لــدي مكفــوفي البصــر، تــرتبط

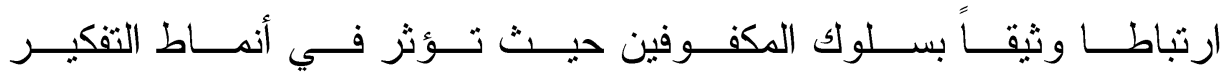

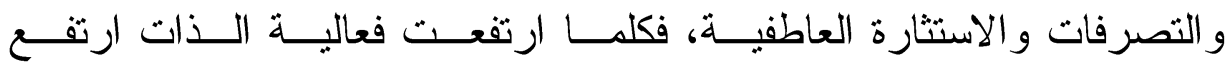

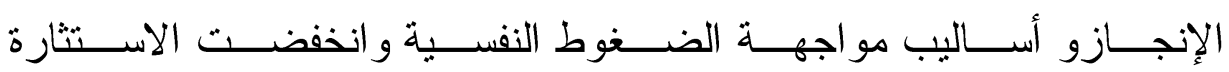

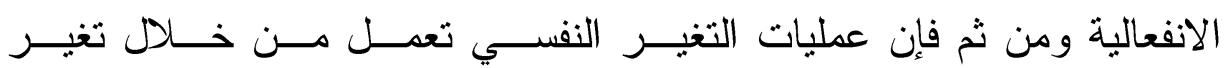

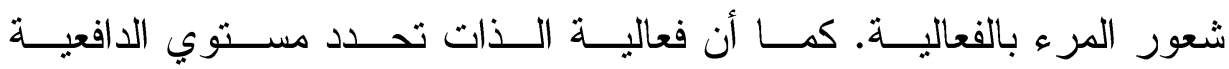

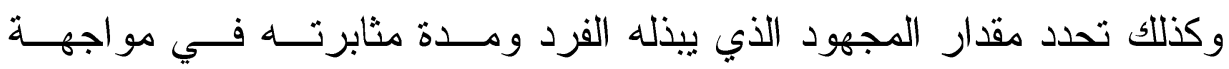

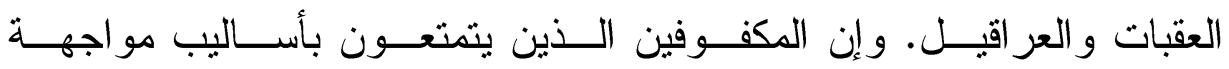

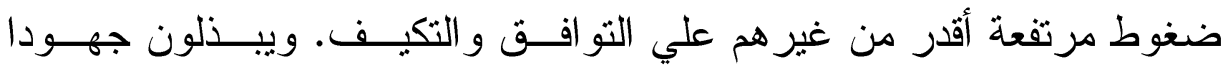

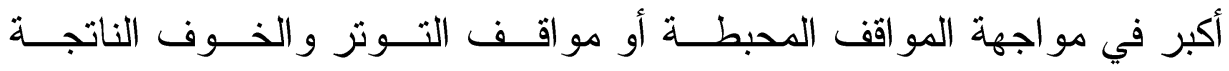

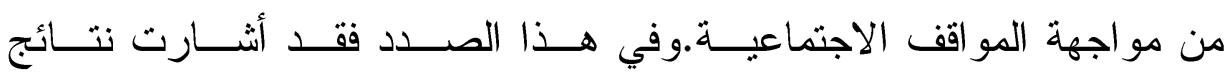

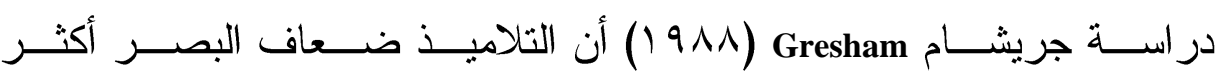

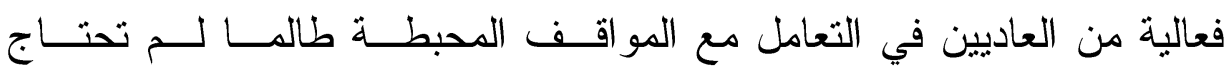
تلك المو اقف إلى مهار ات حركية وهذا ما يدل على صلابة الشخصية.

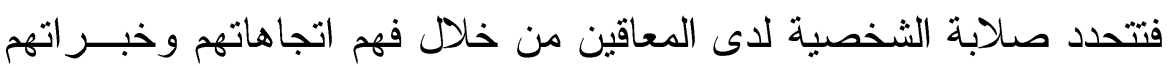

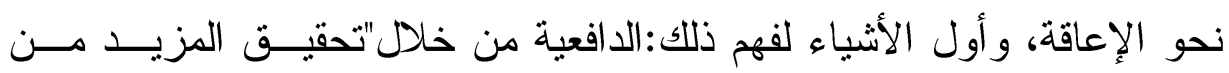

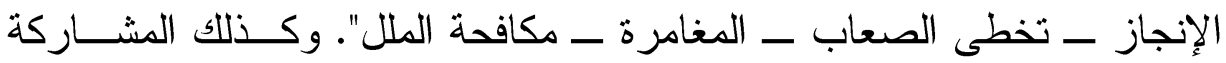

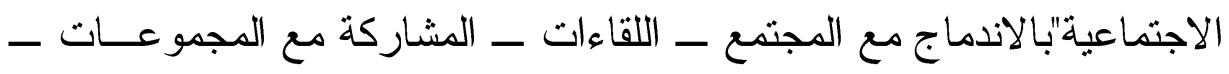

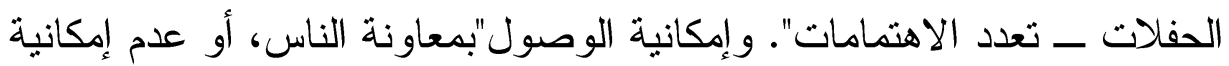

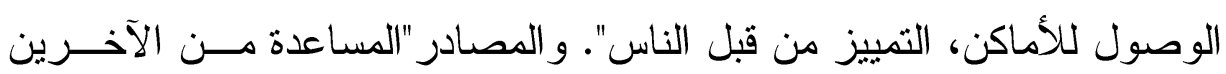

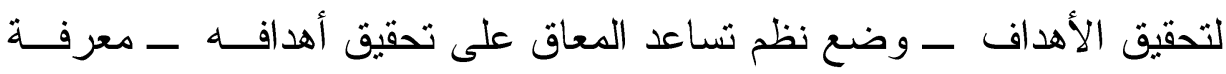

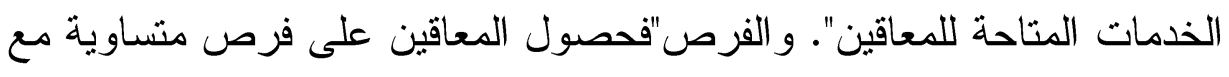


(Feely etal., 2007 , 27 - العاديين - الحصول على فرص كافية لتحقيق ما يريده

وصلابة الشخصية عامل حاسم فـي تحسـين التوافـق و الأداء النفسـي و الاجتماعي و البدني والصحي، فالمتاعب المادية ومشـــاكل العمـلـل وكثــرة الالتز امات هي ضغوطات ولكنها لبست سباً للإصابة بالاضطر ابات، بل ربما

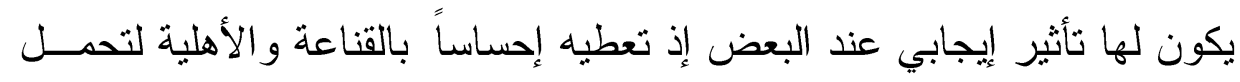
المسؤولية وتشعره برجولته، وبالتالي تصبح محفز ات أكثر منها محبطات، لكن كثرة هذه الالتز امات وزيادتها عن قدرة تحمل الرجل ربما يؤدي إلى دخوله في حالة المرض النفسي. و عليه يمكن القول أن صلابة الثخصية هي اعتقاد عــام لدى الفرد بفاعلية وقدرثه على إدر الك وتفسير أحداث الحياة الضـاغطة وتحمـلـل الضغوط ومو اصلة الحياة الاجتماعية. لذلك يمكن القول أن الصـلابة الشخصية من المتغير ات الايجابيــة و الدالــة

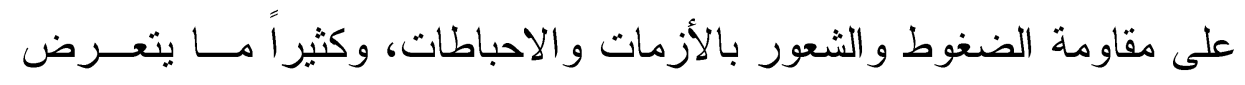

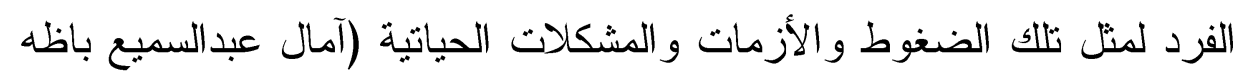

$(\Lambda, r, 1)$

و عليه تخلص الباحثة أن الصلابة قد تتأثر بالعديد من المتغيرات أو العوامل كالسمات الشخصية للفرد (مثل التقدير العالي للـذات والــكاء و الاســتقلالية و الكفاية) و المساندة الاجتماعية المتمثلة في (تر ابط الأسرة وتماسكها و إحساس الفرد بالدفء) ووجود أنظمة مساندة للفرد تجعله يشعر بالاستقر ار النفسـي) لهذا يبدو أن صلابة الشخصية تتمثل في عدد من السمات النفسـية وأســاليب المو اجهة الحياتية التي تؤدي إلى قوة شخصية تمكن الفرد من استخدام مصادره الذاتية و البيئية في مو اجهة الأحداث و التعامل معها بموضو عية. مشكلة البحث: تتمثل مشكلة البحث في الآتي: - الملاحظة غير المقننة: 
بدأ الإحساس بالمشكلة لدي الباحثة أثثاء الزيار ات الميدانية لها لمدرسة النور

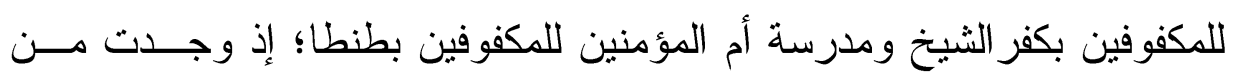
ملاحظاتها غير المقننة أن هناك بعض الأطفال المكفوفين المقيمين إقامة داخلية

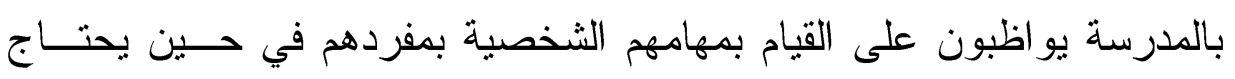

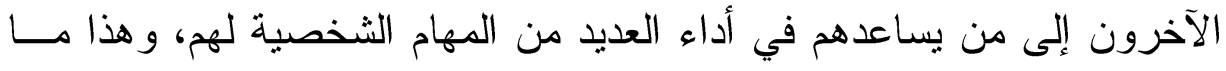

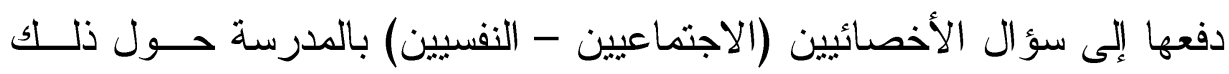

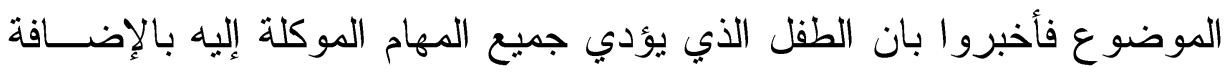

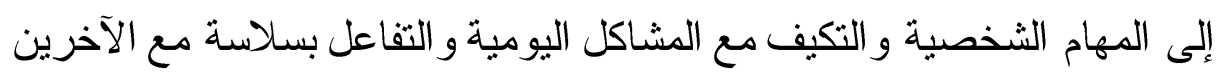

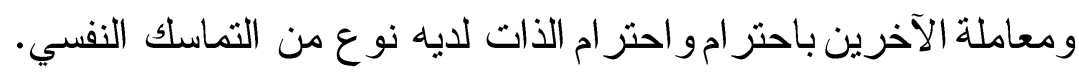

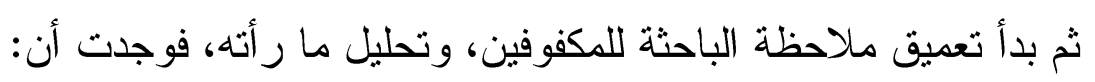

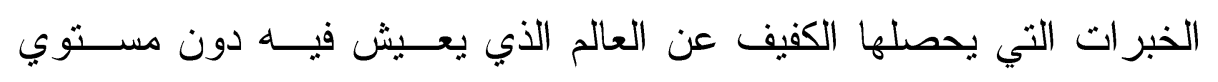

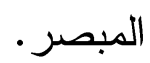

الحواس الأربعة الباقية للكفيف هي أساس تعلمه لو استغلها بصورة كلية.

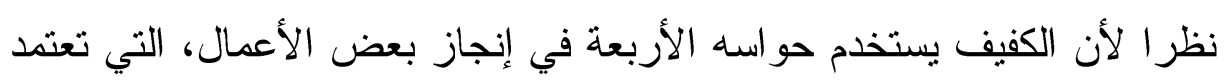

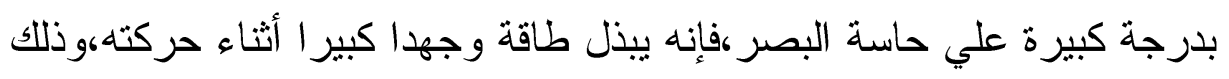

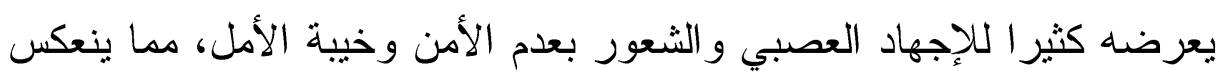
أثره سلبا علي شخصيته. تحصيل الخبرات عند الكفيف تكون أقل مقارنة بالطفل المبصر . بتقبل الكفيف إعاقته أو يرفضها في ضو أل الاتجاهات الو الدية نحوه.

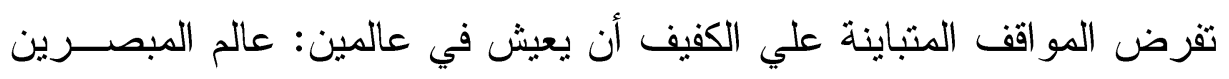
و عالمه الخاص المحدود، ولكن حياة المبصرين بالنسبة له صعبة بعيدة المنال

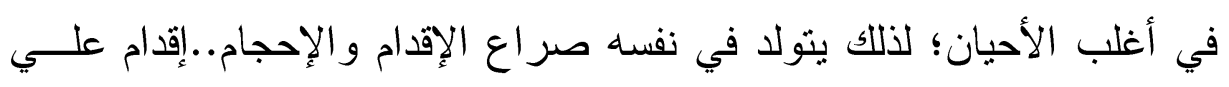

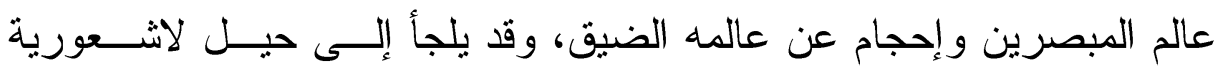

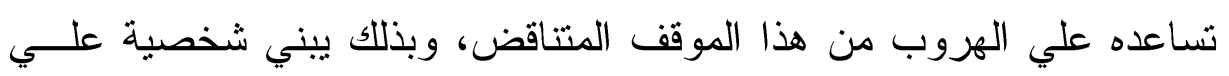


أسس نفسية غير سليمة تجعله يعاني من سوء التكيف مع الآخــرين وتتكسـر صلابة شخصيته.

\section{التراث البحثي:}

من مر اجعة الباحثة لنتائج الدراسات و البحوث في مجال المكفوفين، وجدت أن المكفوفين بتصفون بنقص في بعض الجوانب الايجابية والذي بدوره يؤدى

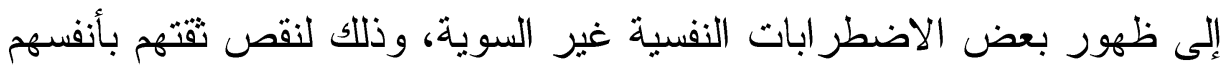

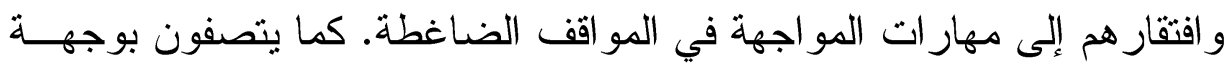

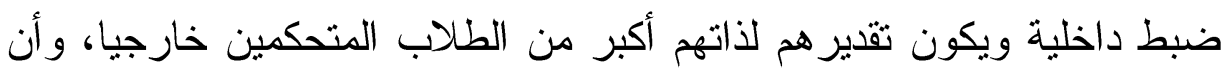

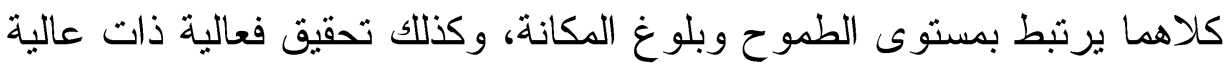
يؤدى إلى وجود تقدير الذات ووجهة الضبط الداخلية.

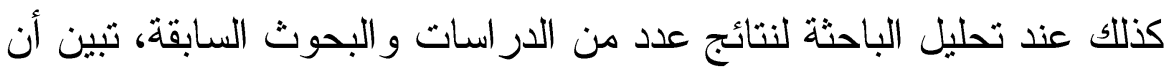

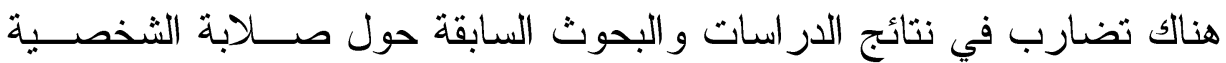

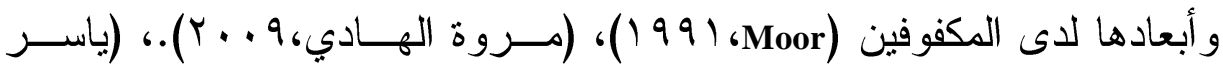

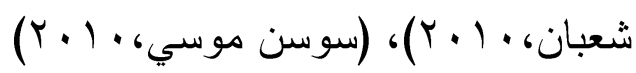

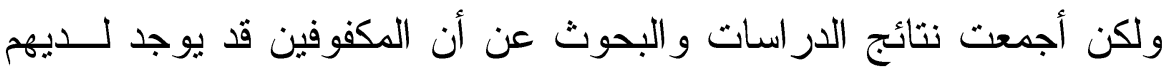

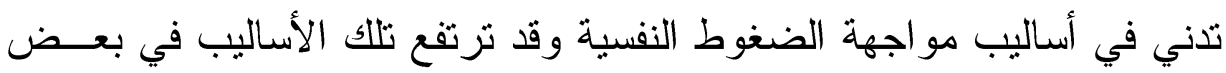

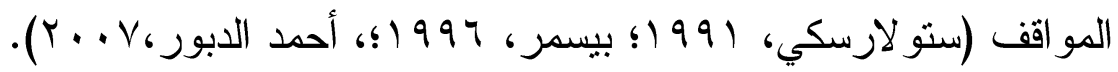
تحديد المشكلة:

يمثل المكفوفين إحدى الفئات الهامة التي تشكل فئة غير قليلة من الأفــر اد

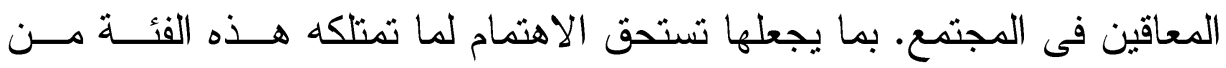

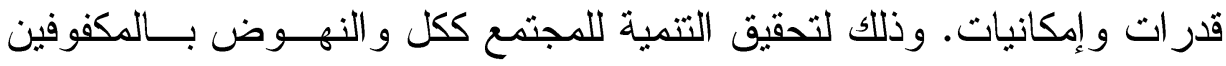

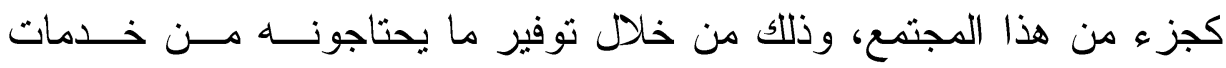

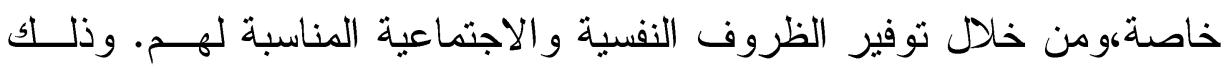
لتمكينهم من وضع أهداف للمستقبل و العيش لتحقيقها، وتغيير نظرتهم للحيــاة ونهاة

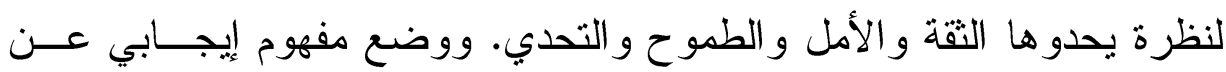


ذاتهم، والتمكن من التقدير الموضوعي لها. خاصة أن فقدان حاســة البصــر

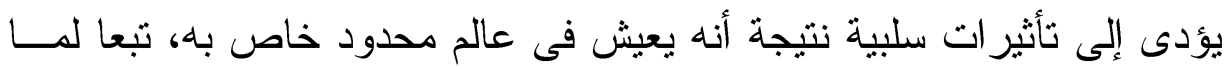

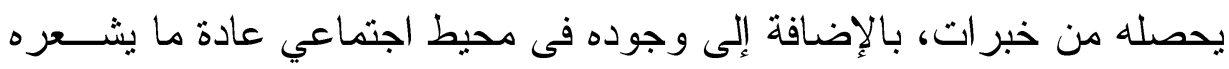

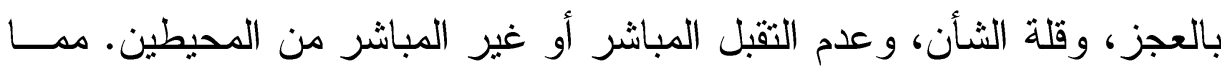

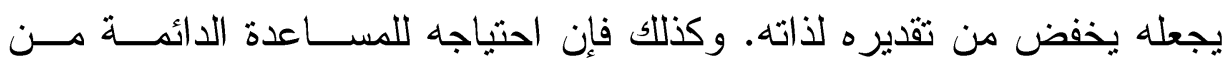

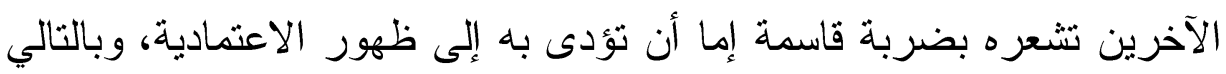

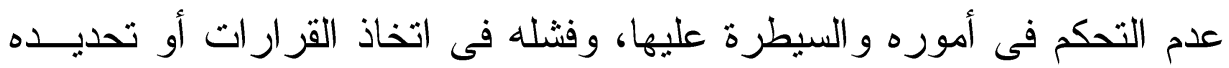

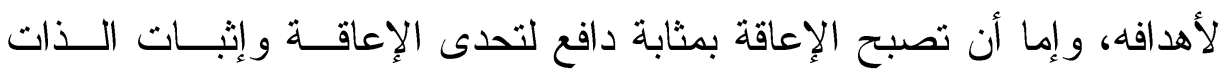

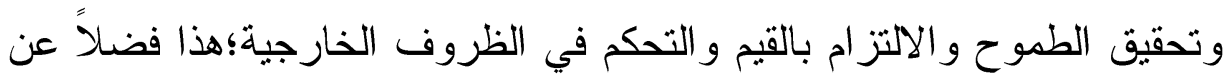

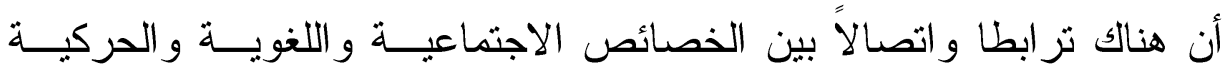
و الانفعالية)التي يخلفها كف البصر على حياة الكفيف. فالجانب اللغـــوي يـؤئر على الجانب الاجتماعي، وكذللك الجانب الحركي يؤثر على الجانب الانفعالي،

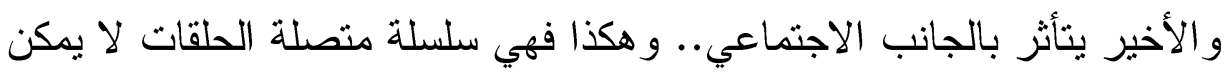

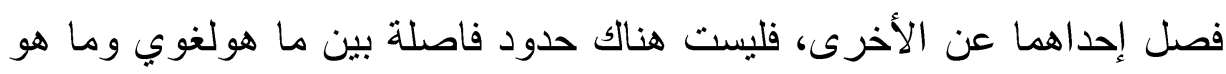

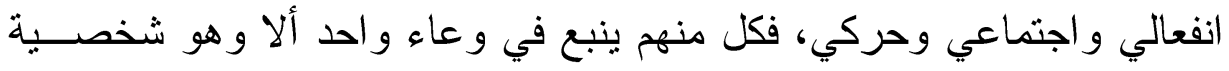

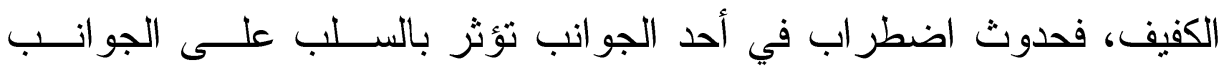

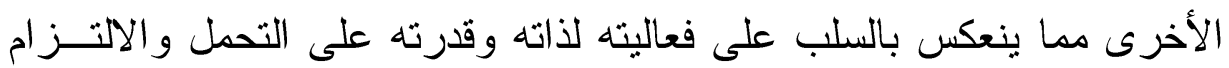

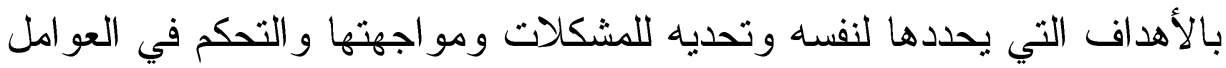
الخارجية مما قد يترك آثاره على صلابته النفسية.

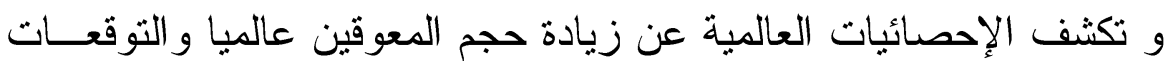

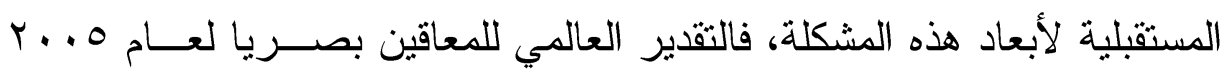

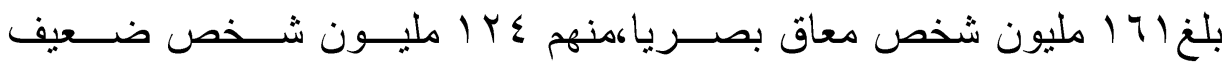
البصر، rV، مليون شخص كفيف. وتتضح من خلال الثكل التالي النسبة المئوية

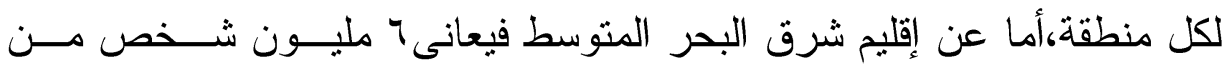


صلابة الثخصية وعلافتها بأساليب مواجهة الضغوط النفسية لاى المر اهقين المكفوفين د. سهام عبد الغفور

العمى، بينما يعانى ب مليون آخرين من شكل أو أخر مــن أثـــال الإعاقــة البصرية:

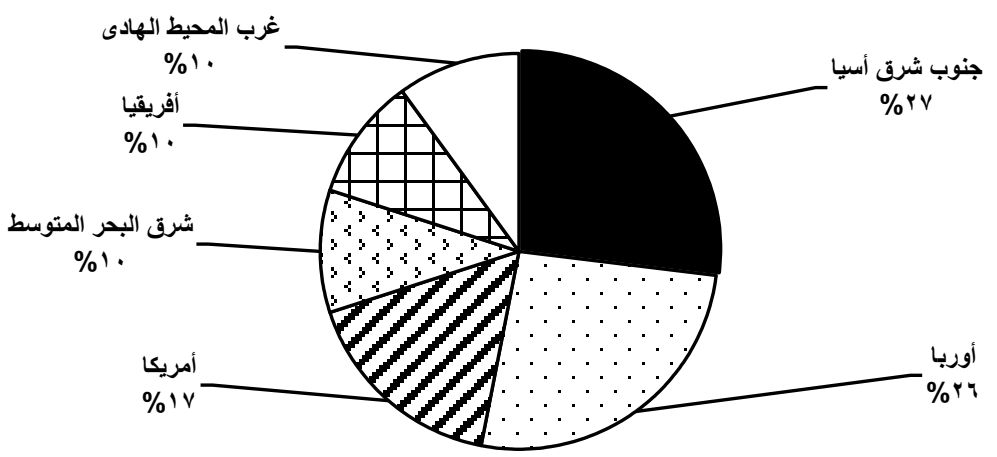

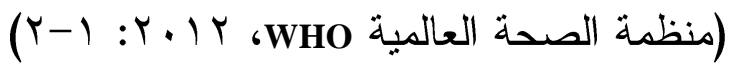

كما يو اجه الكفيف عديدا من المشكلات تفرضها عليه الإعاقة. ولكي ينغلب أبهابه

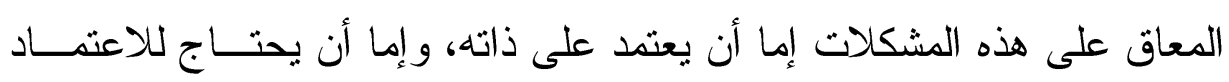

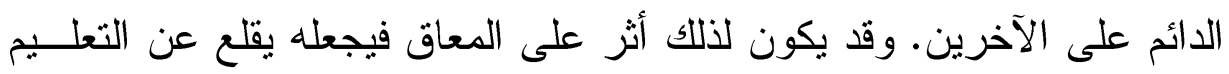

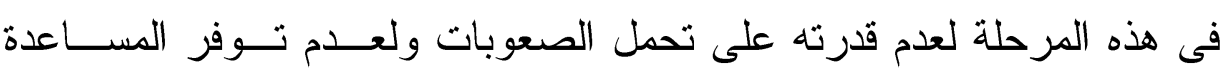

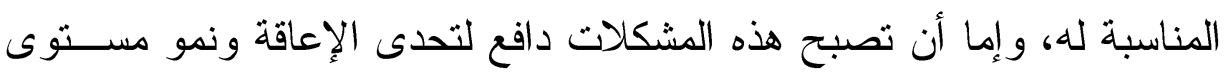

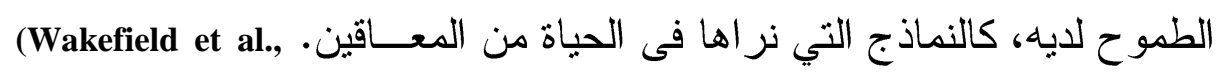
2006,307)

لـــا يحاول البحث الحالي الإجابة على الأسئلة الآتية:

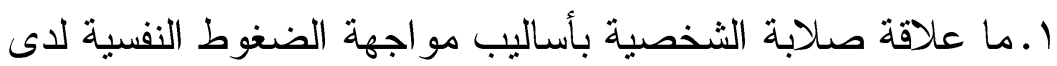

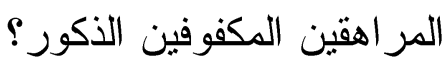

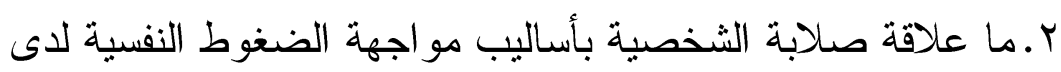

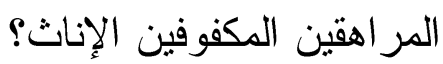
r. هل توجد فروق بين الذكور و الإناث من المر اهقين المكفوفين في صلابة الإنة الثخصية؟ ع. هل توجد فروق بين الذكور والإناث من المر اهقين المكفوفين في أساليب

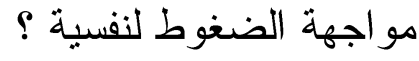




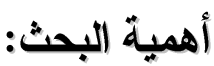

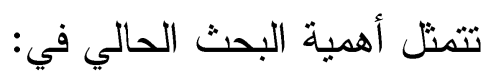

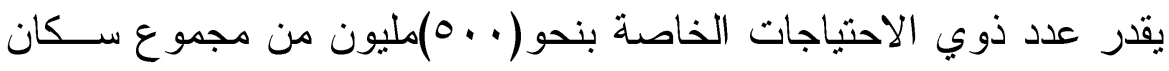

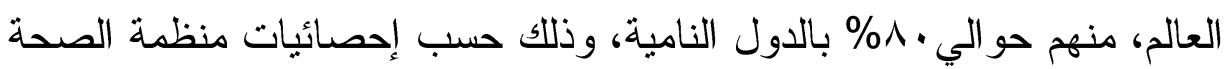

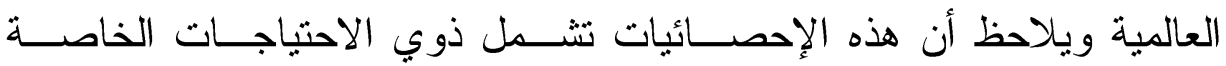

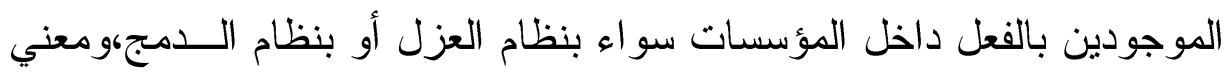

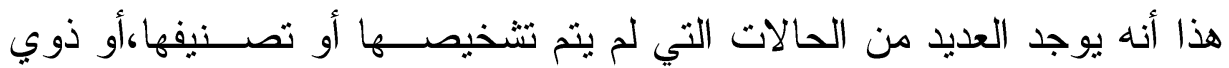

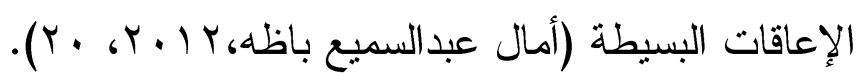

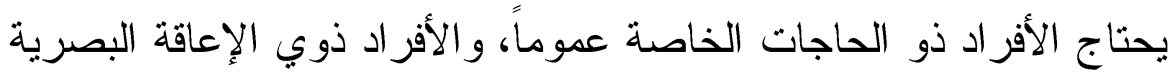

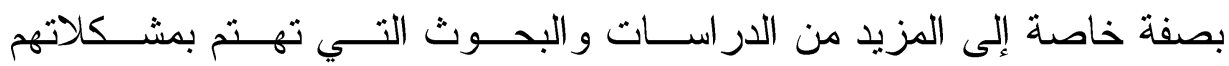

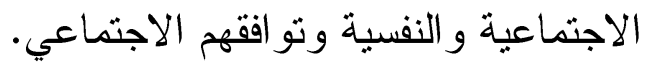
كما يؤكد البحث الحالي على أهمية دراسة النواحى الإيجابية فى الثخصية بصفة عامة ولدى الكفيف بصفة خاصة. إثراء البيئة العربية بتر اث ثري حول طبيعة مفهوم الصــلابة الشخصــية

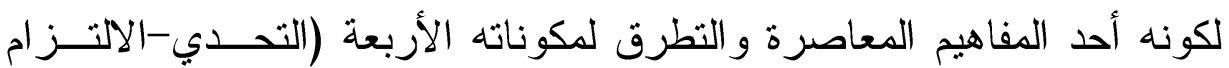

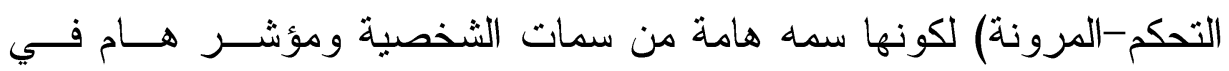
مواجهة الضغوط و التخلص من التوترات وتحقيق النجاح الأكاديمي و المهنـي هوني هوني و تحقيق السواء و التو افق النفسي و الاجتماعي و الجسمي........إلخ.

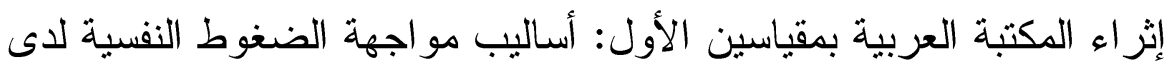
المكفوفين، و الثاني: للصلابة الثخصية لدى المكفوفين.

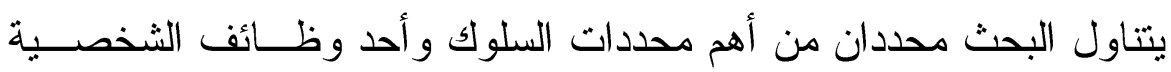

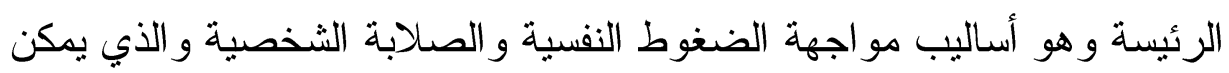

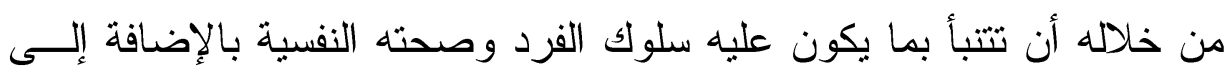
دور ذلك المستوى كمتغير رئيسي فى تقدير الفرد لذاته وما يتعلق بنجاح الفرد

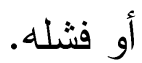




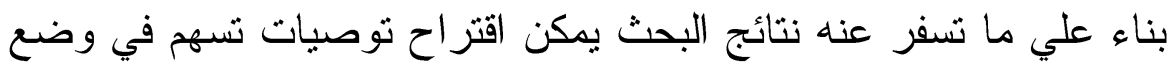

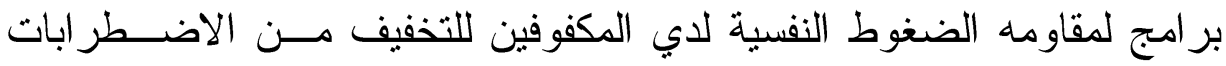
النفسية والاجتماعية وتتمية مهار ات التأقلم الاجتماعي وتحقيق التوازن النفسي.

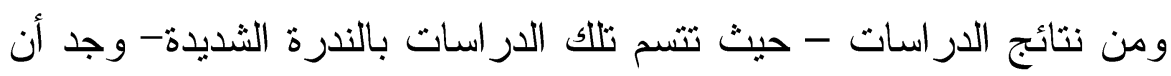

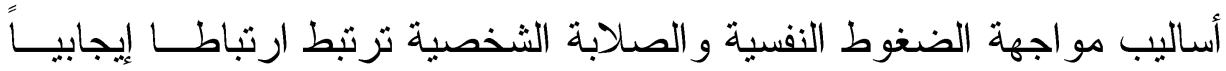

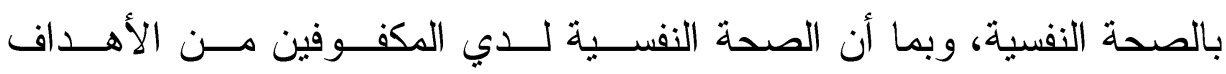

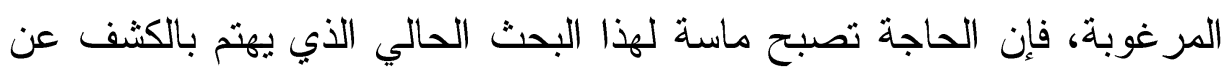

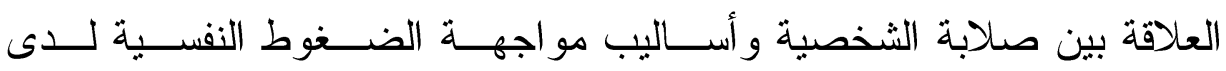

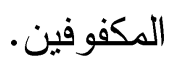

$$
\text { أهداف البحث: يهدف البحث الحالي إلى: }
$$

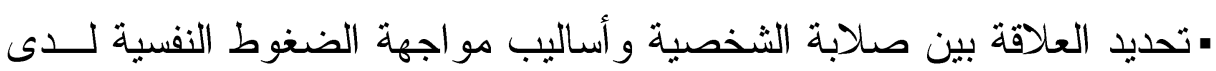
المر اهقين المكفوفين الذكور.

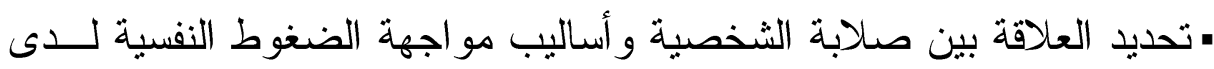
المر اهقين المكفوفين الإناث. • الكثف عن الفروق بين الذكور والإناث من المر اهقين المكفوفين في صلابة الإنة الشخصية. • الكثف عن الفروق بين الذكور والإناث من المر اهقين المكفوفين في أساليب مو اجهة الضغوط لنفسية. مصطلحات البحث الإجرائية: personality hardiness صلابة الثخصية

"اعتقاد عام لدى الكفيف في قدرته على استخدام كل المصادر النفسية و البيئيـــة

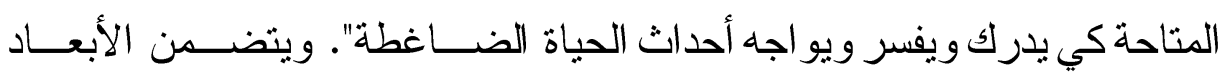
الآتية: •الضبط وهو اعتقاد الفرد أنه يمكنه التحكم فيما يو اجهه من أحداث. 
• التحدي وهو اعتقاد الفرد بقدرته على مواجهة ما بطرأ على حياته من

تغيير

• الالتز ام وهو اعتقاد الفرد بأنه ملتزم اتجاه نفسه و اتجاه الآخرين.

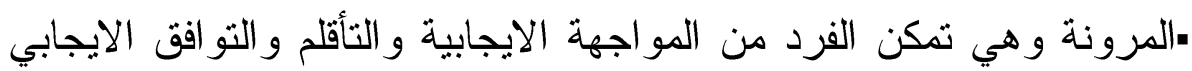
مع التهديدات أو العثر ات أو النكبات التي يتعرض لهن لها لها في حياته.

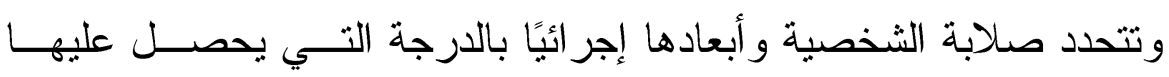
الكفيف على مقياس صلابة الثخصية بأبعاده الأربعة إعداد/الباحثة.

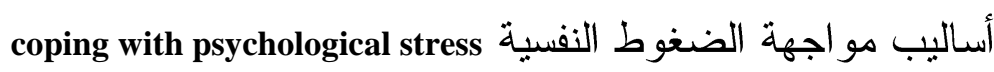
"اعتقاد الكفيف بأن لديه القدرة علي ممارسة السيطرة علي البيأسـة و إنجــاز

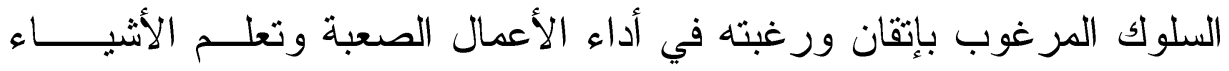

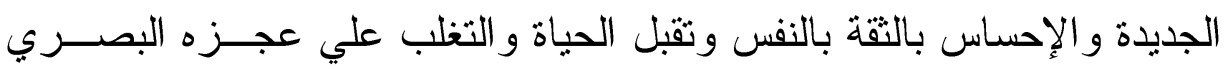

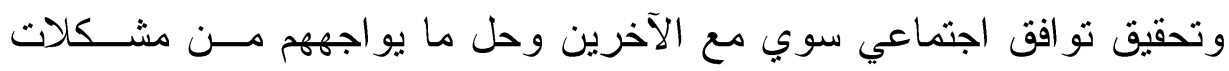

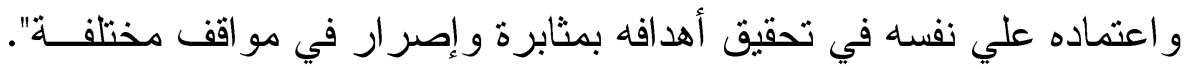

\section{الكفيف BLIND}

" الطفل الذي فقد بصره كليا ممن ولدوا أو أصبب قبــل ســن الخامســة، ويعجز في الحصول علي المعرفة بنفسه لكنه يستطيع الحصول عليها من خلال

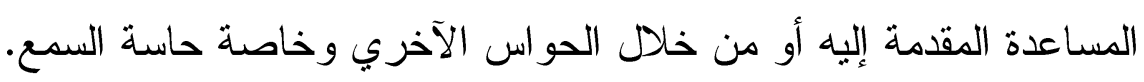
الإطار النظري personality hardiness:[1] أ- مفهوم صلابة الشخصية: تعددت تلك المفاهيم، منها:

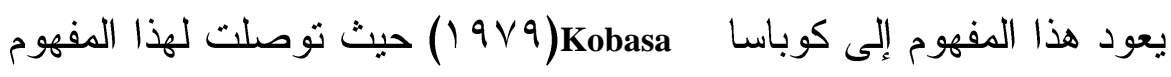

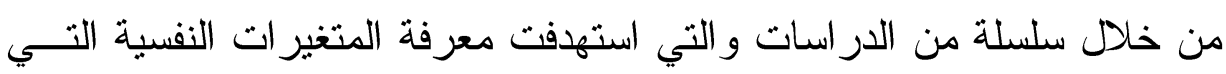

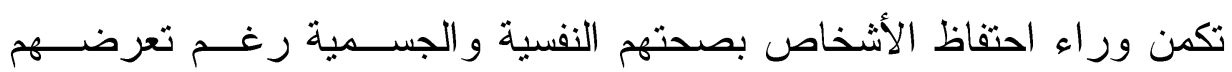
للضغوط. 


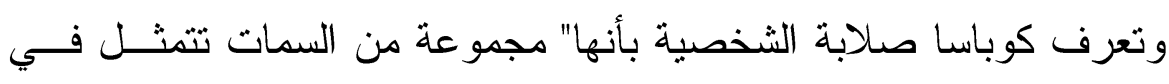

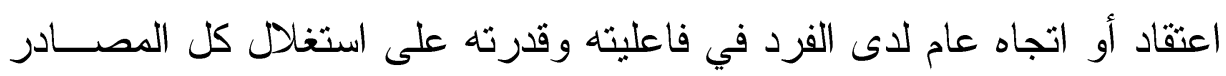

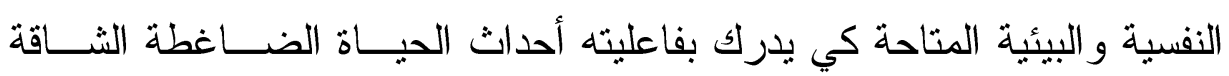

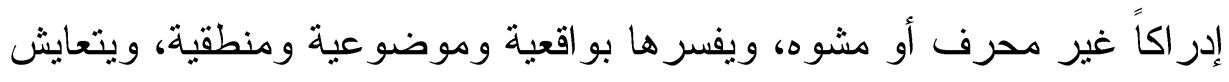

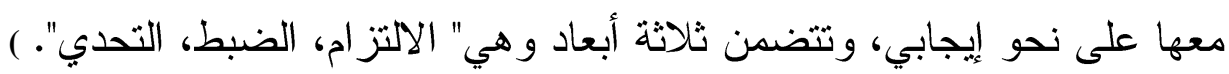

Kobasa,1979,33)

" خصلة عامة في الثخصية تعمل على تكوينها وتتميتها الخبرات البيئيــة

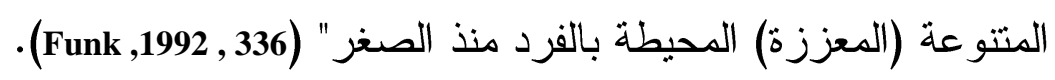

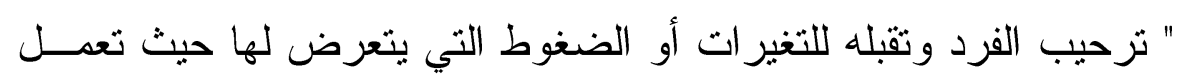

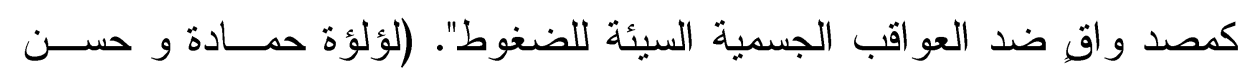

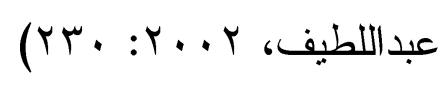

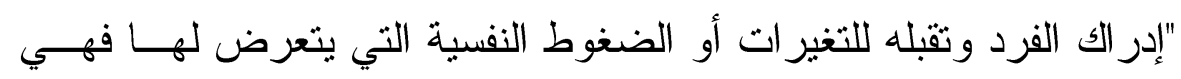

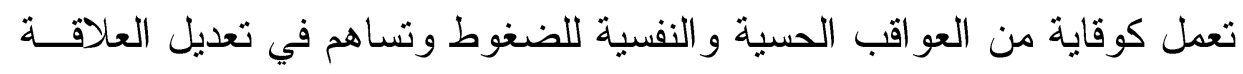

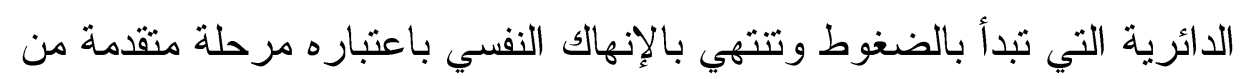

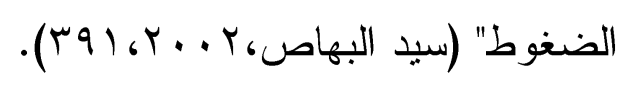

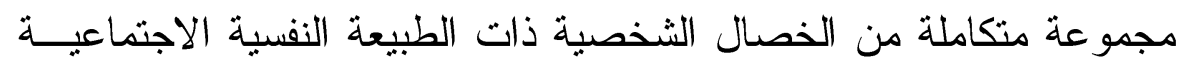

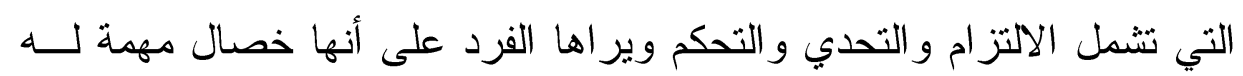

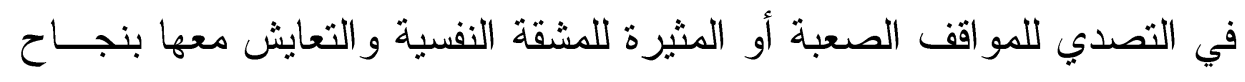

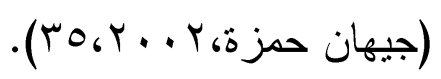

القوة والمقاومة و القدرة على التحمل أثناء الأزمــات واسـتـغلال الفـرص و المناسبات (Johnson, 2004).

"اعتقاد عام لاى الفرد في قدرته على استخدام كل المصادر النفســــة و البيئيـــة

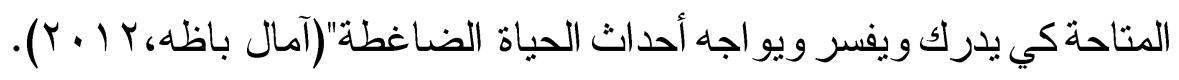

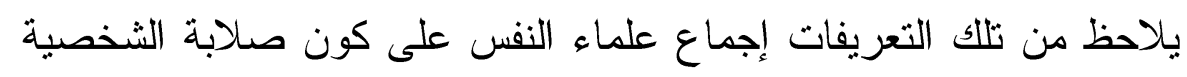

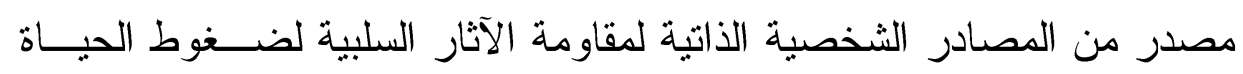

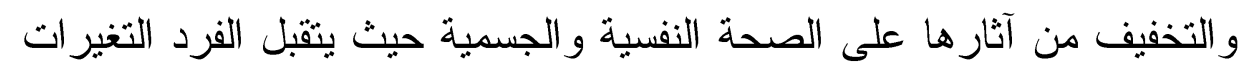


و الضغوط التي يتعرض لها وينظر لها على أنها نوع من التحدي وليس تهديداً فيركز جهوده على الأعمال التي تؤدي غرضاً معيناً وتعود عليه بالفائدة.

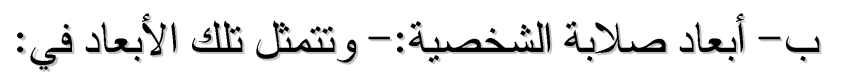

$$
\text { 1 الالتز ام:COMMiтMENT }
$$

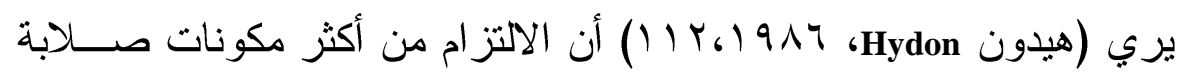

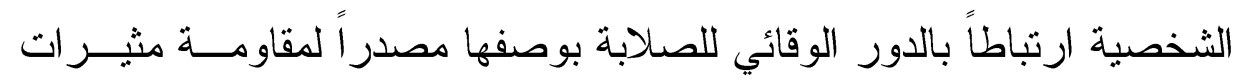

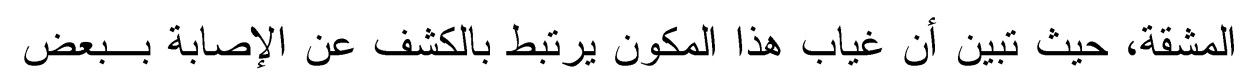

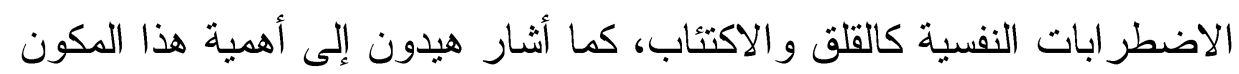
لدى من بمارسون مهنة شاقة كالمحاماة و التمريض وطب الاكب الأسنان.

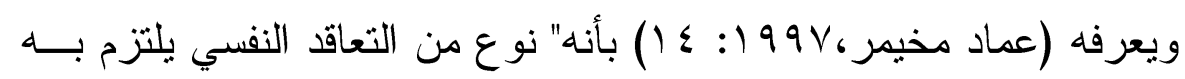
الفرد تجاه نفسه و أهدافه وقيمه و الآخرين من حوله".

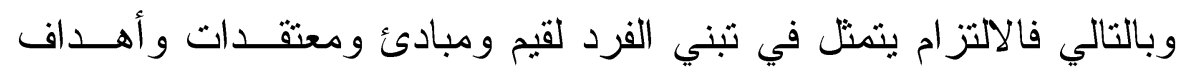

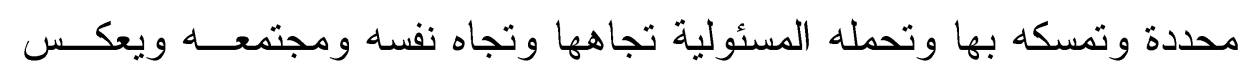
مستوى صلابة الثخصية للفرد.

$$
\text { CONTROL: ب الضبط }
$$

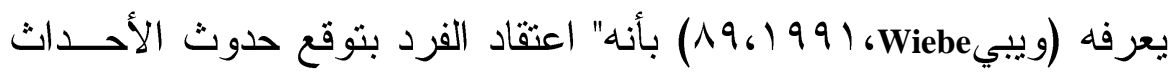

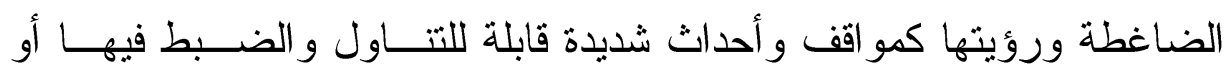
إمكانية الضبط الفعال فيها".

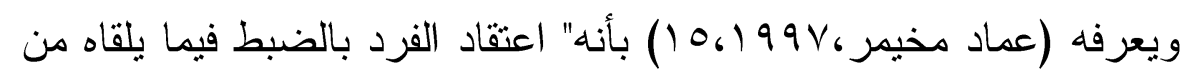
أحداث، وأنه يتحمل المسئولية الشخصية عن حوادث حياته، و أنه يتضمن القدرة

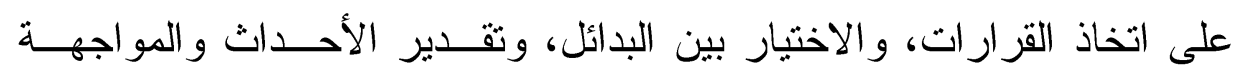
الفعالة".

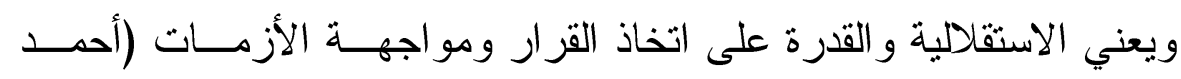

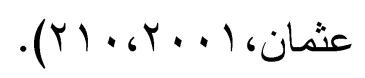




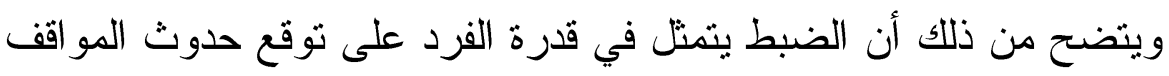
الصعبة بناءً على استقر ائه للو اقع، ووضعنه الخطط المناسبة لمو اجهتها و التقليل

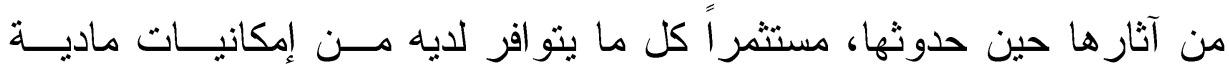
ومعنوية واستر اتيجيات عقلية، مسيطر أ على نفسه، متحكماً في انفعالاته.

\section{r- التحدي:ChalLenge}

هو" اعتقاد الفرد بأن التغيير المتجدد في أحداث الحياة هو أمر طبيعي بـلـل

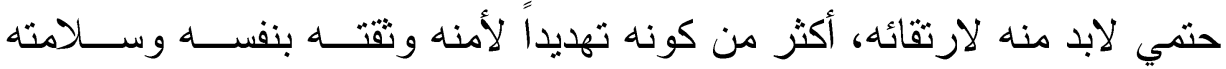

النفسية (Funk , 1992, 336)

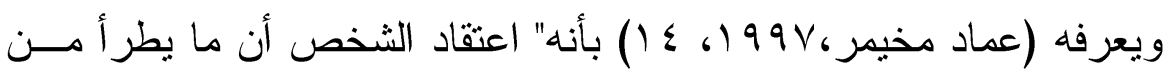

تغيير على جوانب حياته، هو أمر مثير وضروري للنمو أكثر من كونه تهديداً

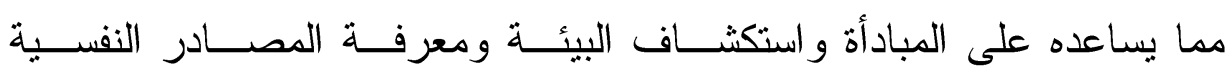
و الاجتماعية التي تساعد الفرد على مو اجهة الضغنوط بفعالية".

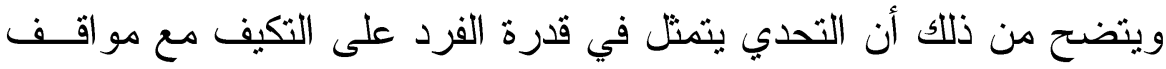

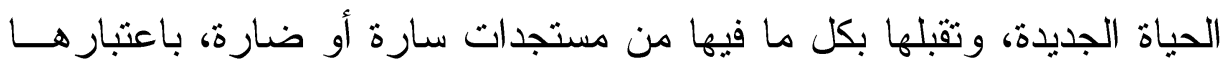

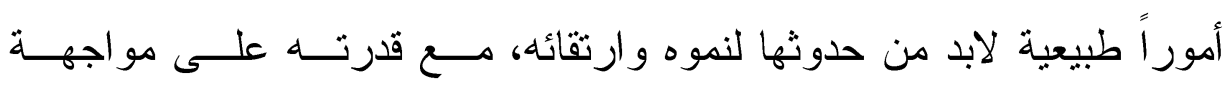
المشكلات بفعالية، و هذه الخاصية تساعد الفرد على التكيف السريع في مو اجهة

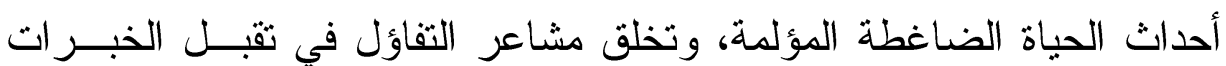
الجديدة.

ع- المرونة:FLEXIBILITY تطلق عليها (آمال باظه، Y ا • Y، Y I) الصــمود

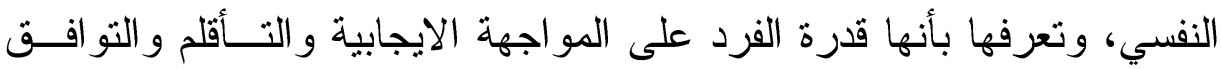

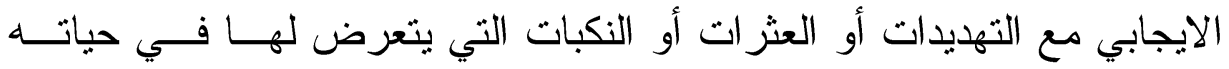

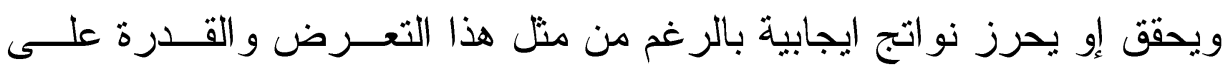

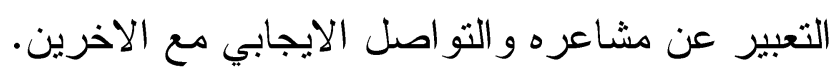




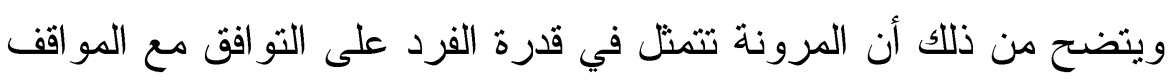

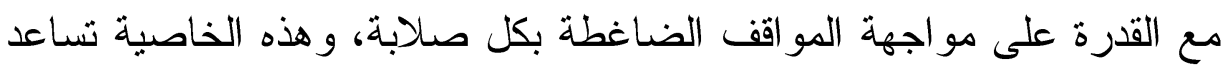
الفرد على التوافق مع المشكلات أثناء مواجهة أحداث الحياة الضاغطة الفياغة المؤلمة. ج- خصائص صلابة الشخصية: توصلت كوباسا من خلال در اســنها (1979 - 1982 - 1983 - 1985) إلـى أن أن

الأفر اد المتمتعين بصلابة الشخصية يتميزون بالخصائص التالية: •القدرة على الصمود و المقاومة. ملديهم إنجاز أفضل. مذوي وجهة داخلية للضبط. •أكثر اقتدار اً ويميلون للقيادة و السيطرة.

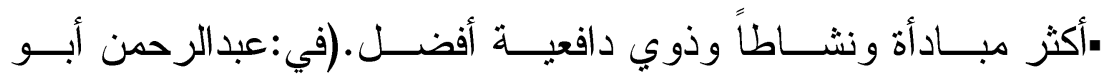

$$
\text { ندى6r) }
$$

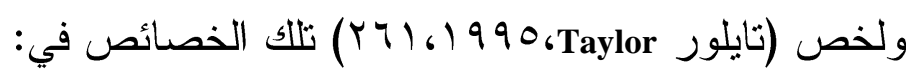

الإحساس بالالتز ام أو النية لدفع النفس للانخر اط في أي مستجدات نز اجهره.

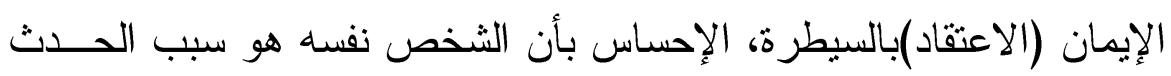
الذي حدث في حياته، وأن الثخص يستطيع أن يؤثر على بيئته.

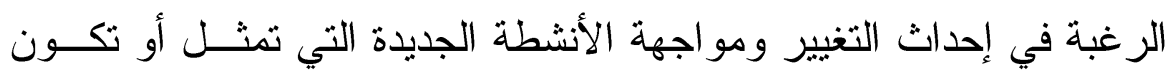

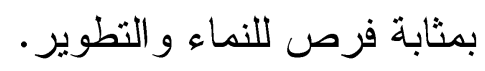

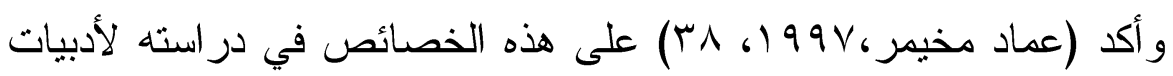
الموضوع، حيث قام بالعديد من الدراسات العربية في مجال صلابة الشخصية لهانية

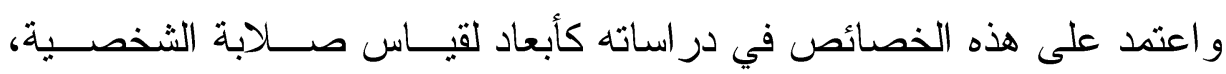
استتاداً إلى تعريف ومقياس الصلابة الذي طورته كوباسا.

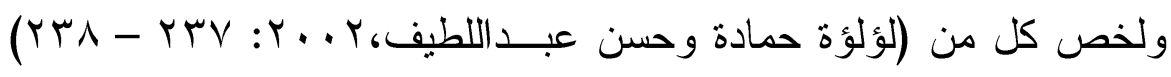
خصائص مرتفعي الصلابة في: ولئ 
صلابة الثخصية وعلاقتها بأساليب مو اجهة الضغوط النفسية لاى المراهقين المكفوفين د. سهام عبد الغفور

• هؤ لاء الأفر اد ملتزمون بالعمل الذي عليهم أداؤه بـــلاً مــن شــعورهم بالمشقة. • ويشعرون أن لديهم القدرة على التحكم في الأحداث بدلاً من شــعورهم

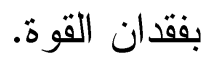
• • ينظرون إلى التغيير على أنه تحد عادي بدلاً من أن يشعر هم بالتهديد.

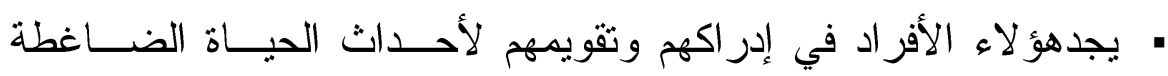
الفرصة لممارسة اتخاذ القرار . مما سبق يتضح أن ذوي صلابة الثخصية يتميزون بما يلي:

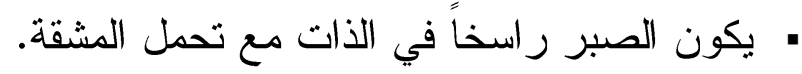

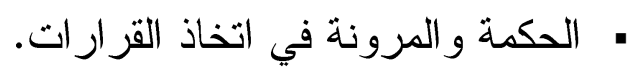
• عدم فقدان التوازن في الأزمات.

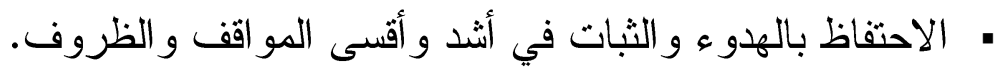
• القدرة على وضع الخطط لمو اجهة المشكلات. • الالتز ام بقيم ومبادئ ومعتقدات معينة و التمسك بها و عدم التخلي عنها. • القدرة على التكيف مع مو اقف الحياة الجديدة. • المبادرة لحل ما يو اج8هم من مشكلات. • التحكم في الانفعالات و الغضب و السيطرة على منى النفس. د - أهمية صلابة الشخصية: تعد صلابة الشخصية مركباً مهماً من مركبات الشخصية القيادية، التي تقي

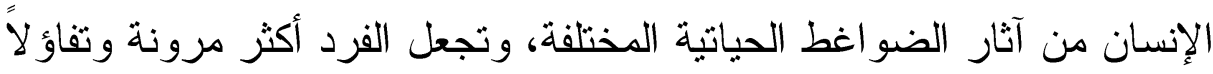
وقابلية للتغلب على مشاكله الضاغطة، كما تعمل صلابة الشخصـــية كعامـلـل حماية من الأمر اض الجسدية و الاضطر ابات النفسية.

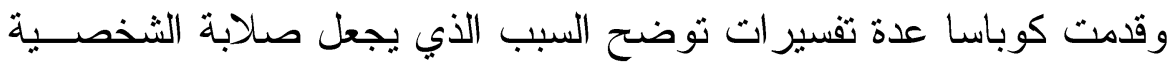

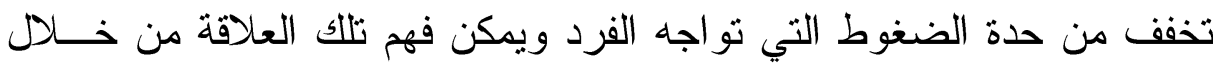
فحص أثر الضغوط على الفرد وفي هذا الخصوص ترى كـلـ مــن مــادي 
وكوباسا أن الأحداث الضاغطة تقود إلى سلسلة من الأوجاع تؤدي إلى استثارة

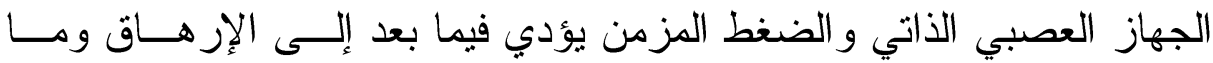

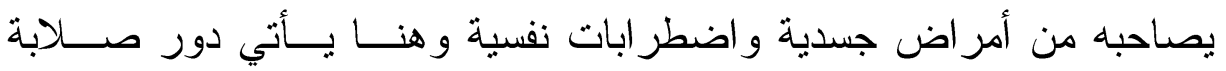

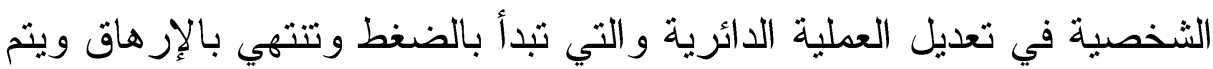
ذلك من خلال طرق متعددة فالصلابة: • تعدل من إدر الك الأحداث وتجعلها تبدو أقل وطأة.

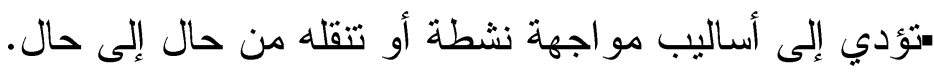

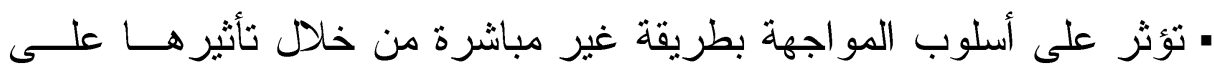

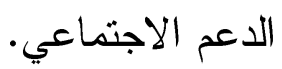

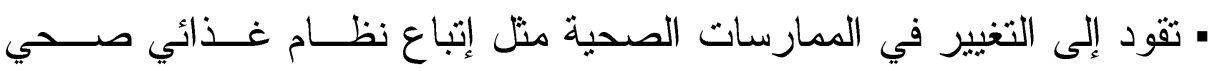
وممارسة الرياضة. و هذه بالطبع تقلل من الإصابة بالأمر اض الجسمية.

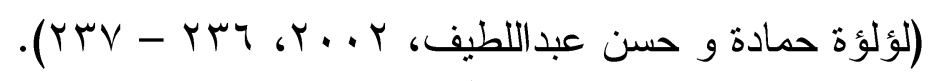

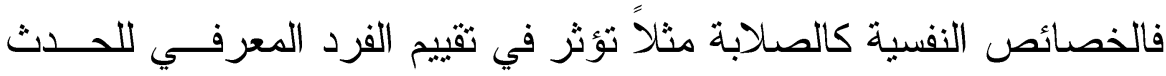

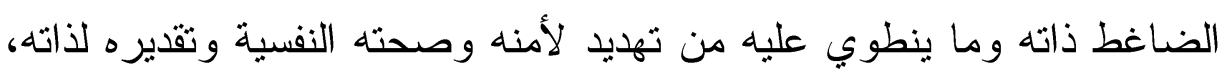

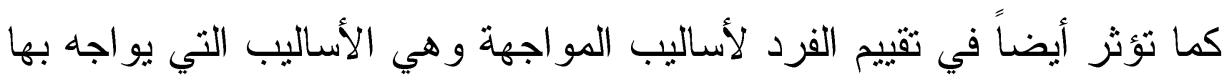
الفرد الحدث الضاغط (مواجهة المشكلات- الهروب- التجنب تحمل المسئولية

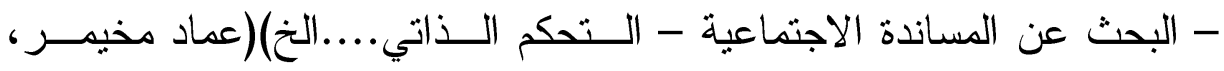
. (YVT:) $99 V$ وتبين أن الأشخاص ذوي صلابة الشخصية أميل لاستخدام طرق المواجهة

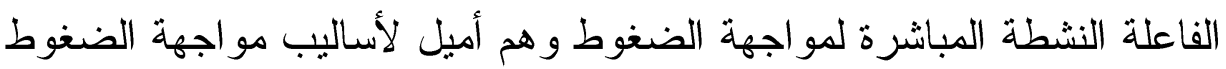
بالتزكيز على المشكلة و إلى المساندة الاجتماعية ويبتعدون عن أساليب التجنب

(Taylor, 1995, 26)

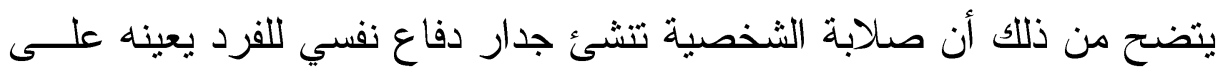
التكيف البناء مع أحداث الحياة الضاغطة و المؤلمة، وتخلق نمطاً من الشخصية

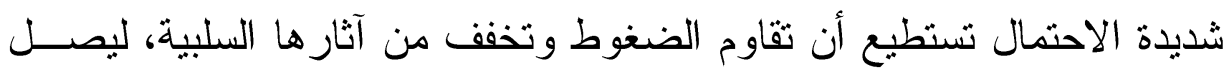




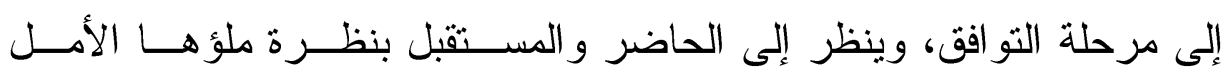

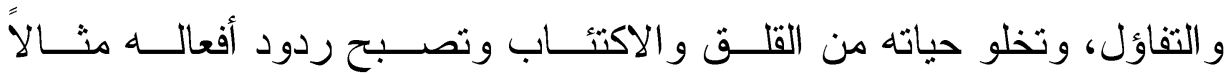

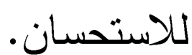

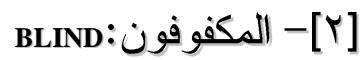
تتفرد حاسة البصر دون غيرها من الحواس بنقــل بعـض جوانسـب العــالم

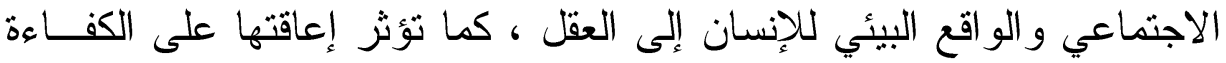

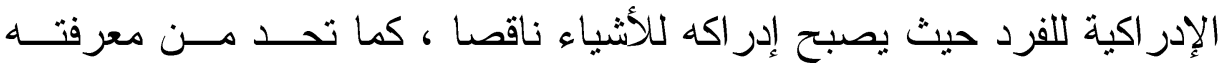
بمكونات بيئته مما تؤدى إلى اضطر اب حركته وقصور مقدرته علــى التنقــلـل وشعوره بالخوف و عدم الأمن.

- مفهوم كف البصر : تعددت تللك المفاهيم تبعا للجهة المحددة لله، فمنها:

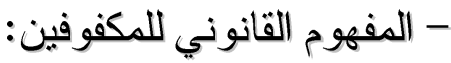
هو "القدرة على تمييز الأشكال بوضوح ح ، أو تمييز التفاصـيل علــى مســافة

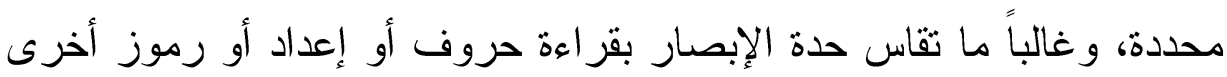
من خريطة على بعد (·r) قدما" (Haward \& Oriansky, 1992,333).

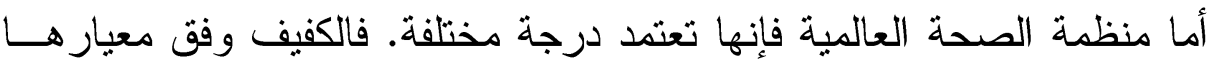

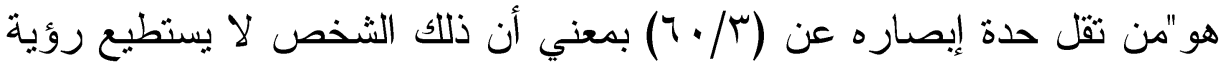

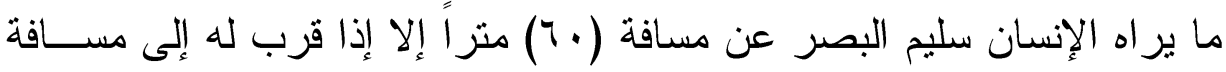

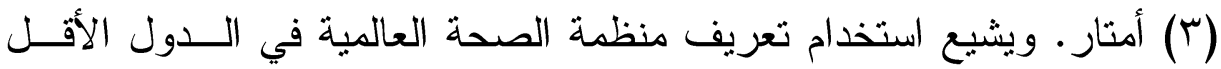

$$
\begin{aligned}
& \text { نموا" (يوسف القريوتي وآخرون، } 990 \text { (1)، 19 ()). } \\
& \text { - المفهوم الاجتماعي للمكفوفين:- }
\end{aligned}
$$

هو "الثخص الذي تمنعه الإعاقة من أن يتفاعل بصورة ناجحسـة مـــع العــالم المحيط به" (Dods , 1986,49).

هو "الثخص الذي لا يستطيع معرفة طريقه دون قيادة في بيئة غير معروفــهـ

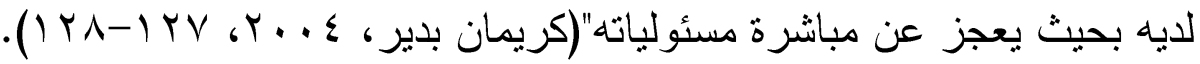

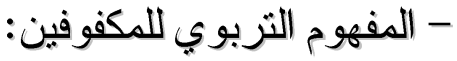


هو "الثخص الذي تكون قوة إبصاره(صفر)أو أقل من ؟1/، ب فـي العـين

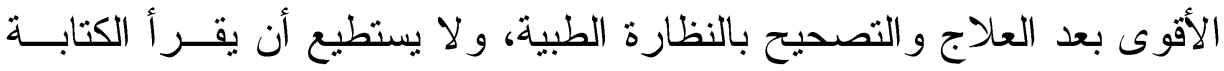

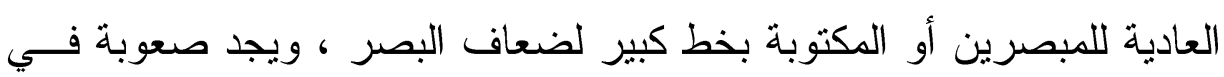

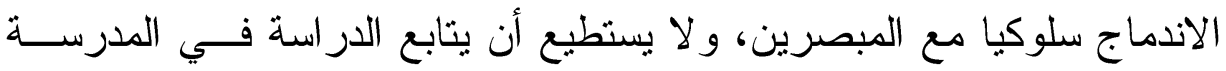
العادية أو في مدرسة ضعاف البصر بنجاح" (Dods , 1986,49).

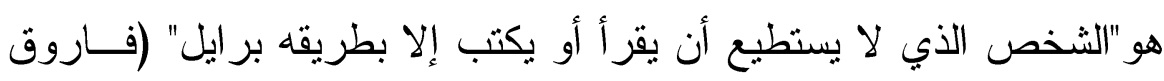

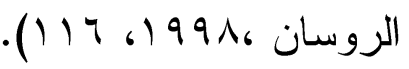

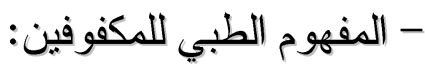

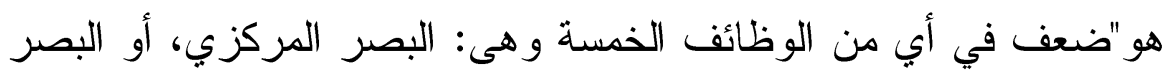

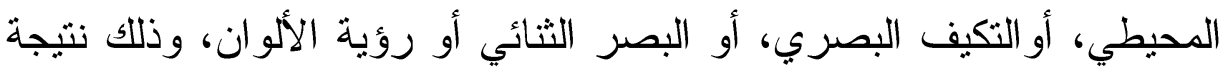

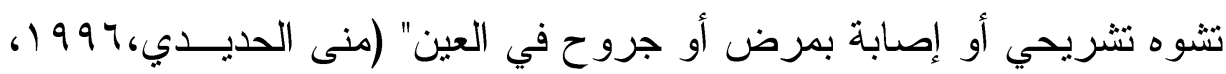

هو"الرؤية الأقل من الرؤية العادية. ونحتاج مزيدا من المعلومات لكي نحدد

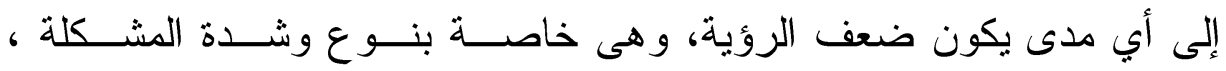

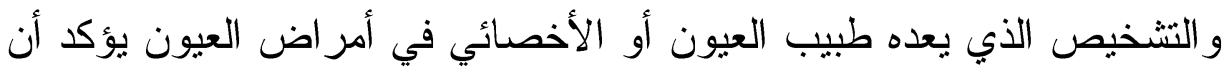

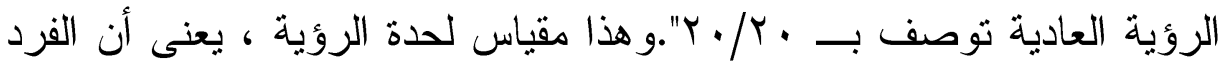

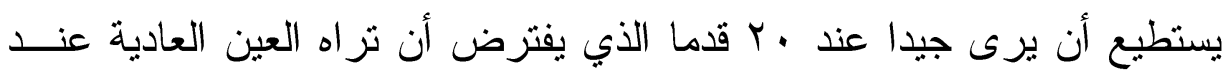

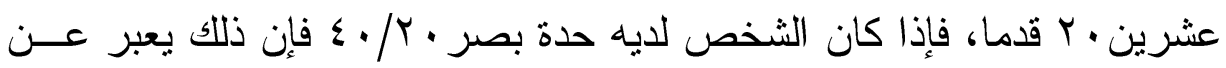

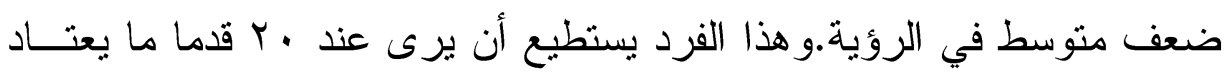

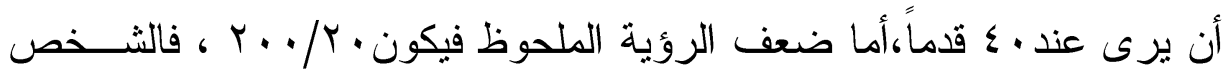

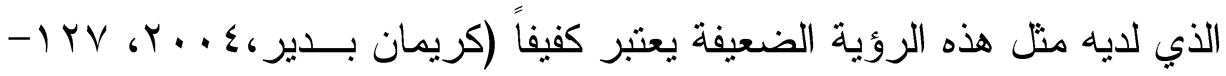
.(1) rर

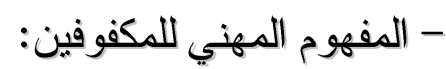
هو "الثخص الذي يستدعى ضعف قوته البصرية التدريب لمهنه ما مناســبة

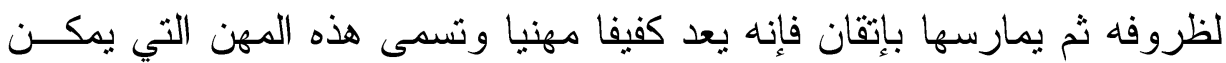




\section{صلابة الثخصية وعلافتها بأسائيب مواجهة الضغوط النفسية لاى المر اهقين المكفوفين د. سهام عبد الغفور}

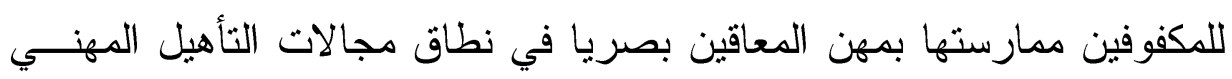

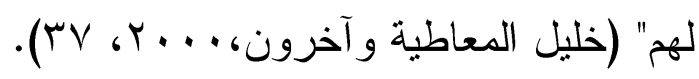

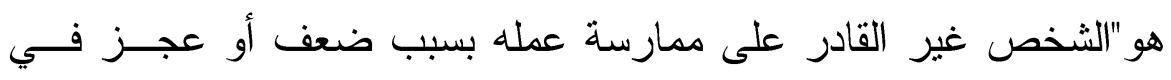

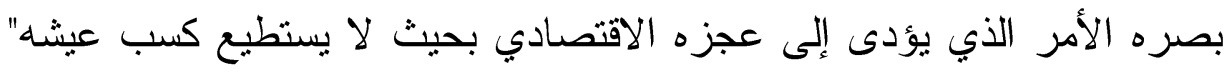

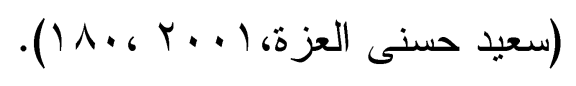

ومن العرض السابق لمفاهيم الكفيف المتعددة ؛ نجد أن تنوعها يعتمد فــي الهي

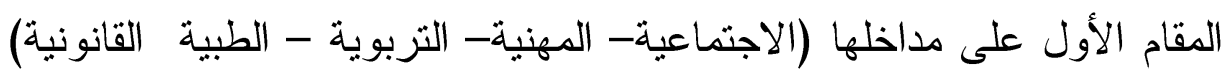

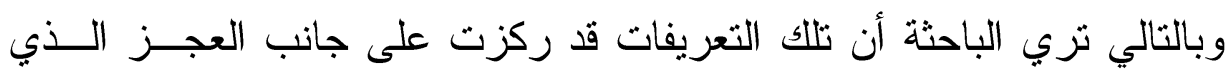

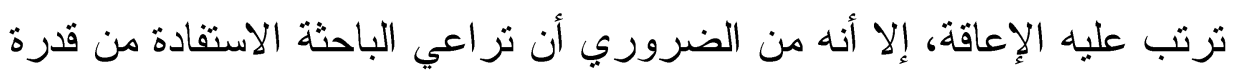

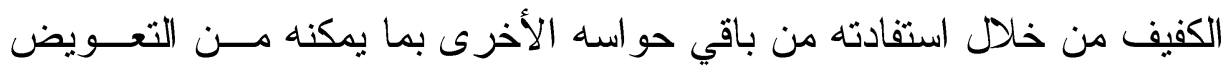

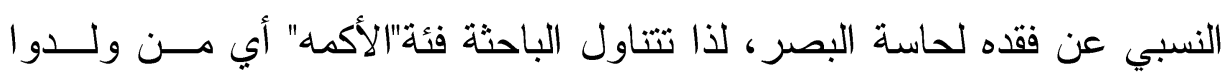

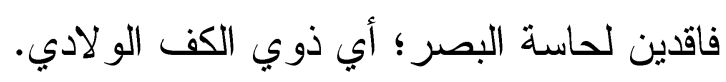
- الاحتباجات النفسية و الاجتماعية للمكفوفين:

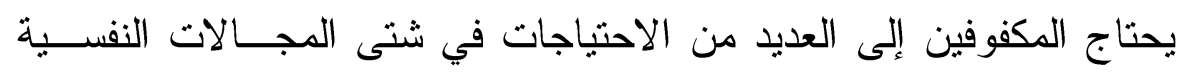

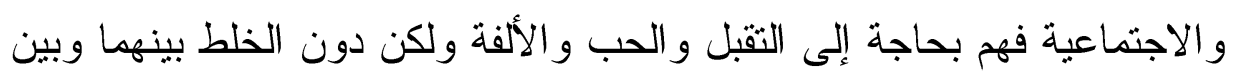

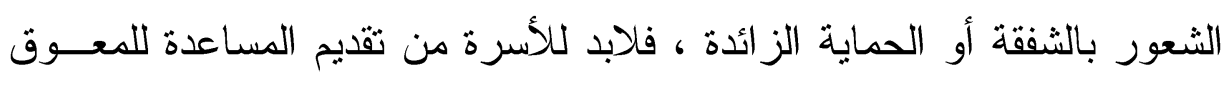

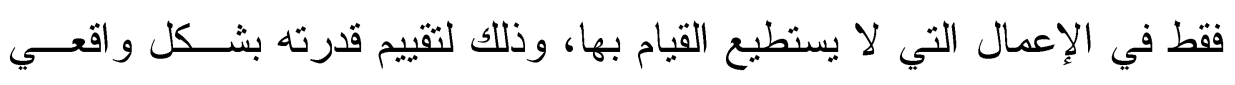

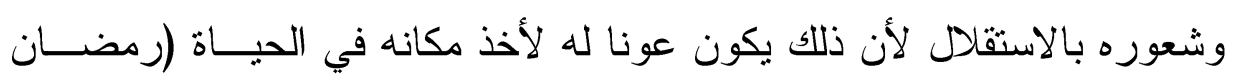
محمد القذافى، ع9 99 (، ع م). ويتفق علماء علم النفس على وجود مجموعـة مــن الحاجـات النفســية الاجتماعية التي تخص المكفوفين منها: •الحاجة إلى التقبل من الأهل والآخرين.

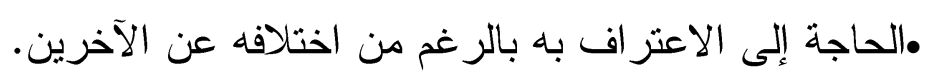

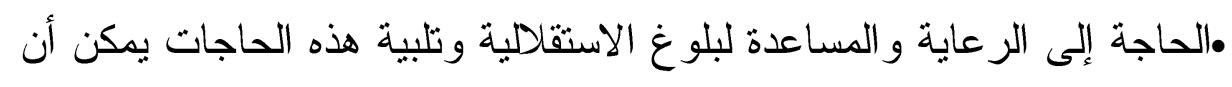

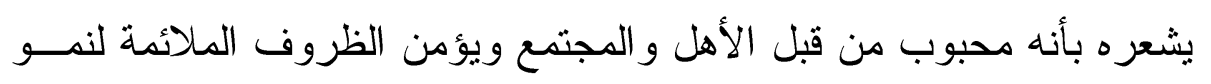


انفعالي يساعده على تجاوز الصعوبات التي تقابله (بســام إليــاس العويـلـل . $(\leqslant 7.19996$

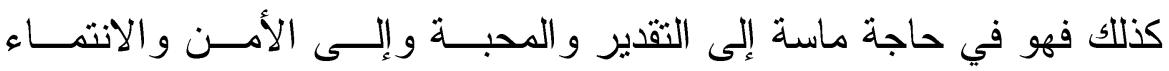

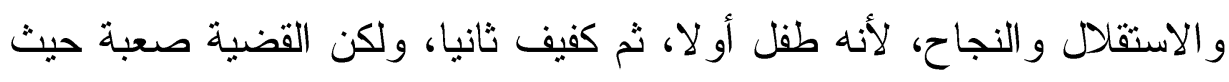

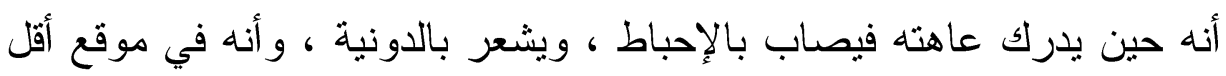

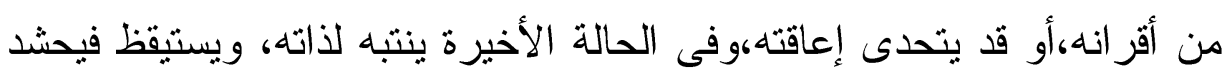

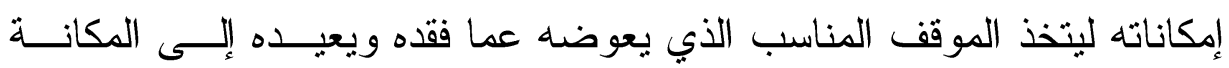

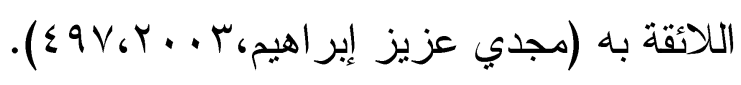

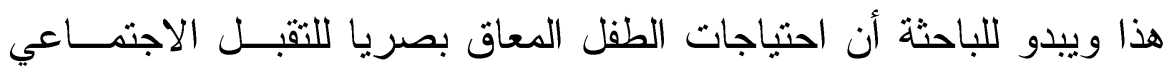
تتصب على الأسرة لما لها من دور هام من حيث مساعدة الطفل المعاق بصريا

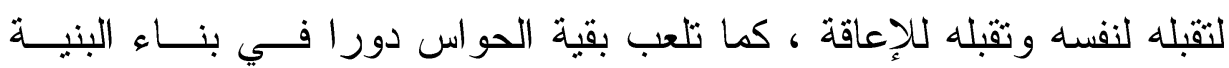
المعرفية و المفاهيمية له وبالتالي تحقيق الاستقلالية.

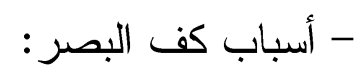

هنالك العديد من الأسباب التي تقف ور اء الإصـابة بكف البصر ، فقد اتفـق كل من (لطفي بركات،

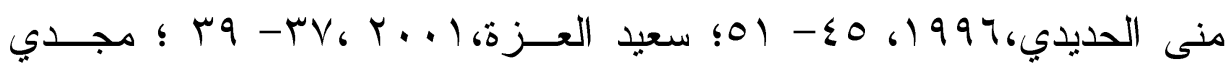

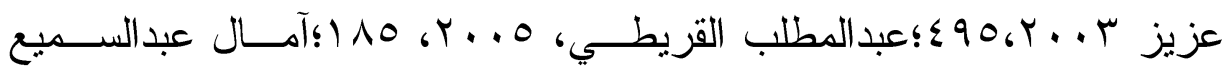

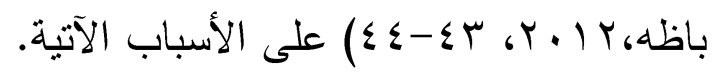

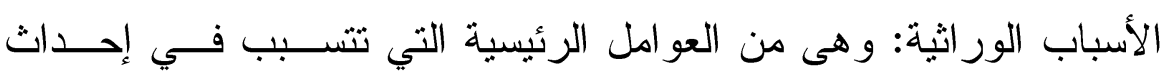

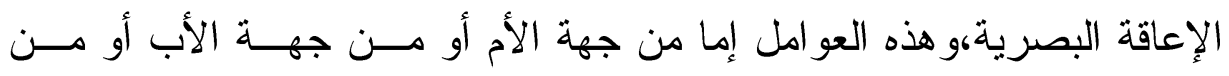

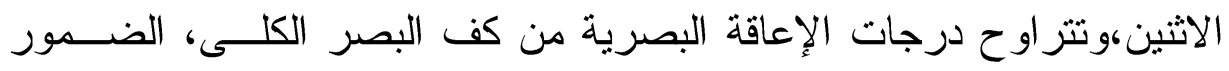

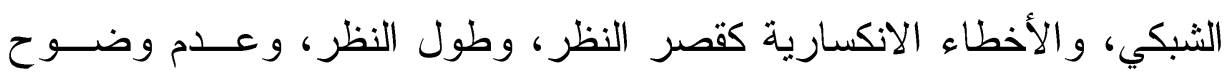

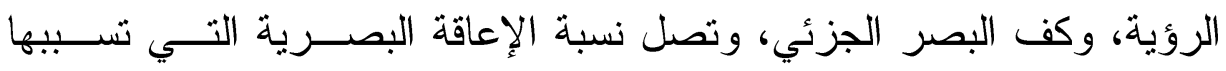

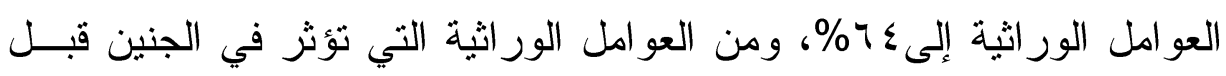


الو لادة بعض الإمر اض الموروثة التي تؤدى إلى حدوث العتامة خلف عدســـة

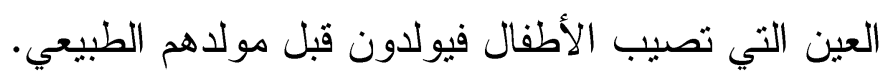

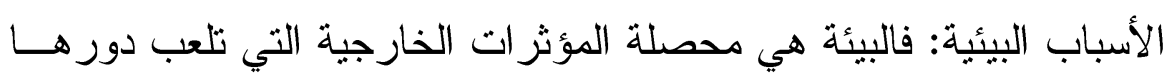

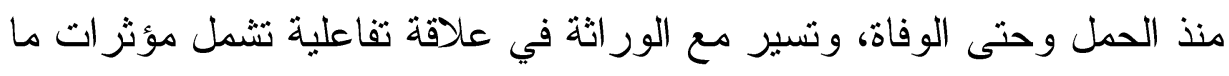

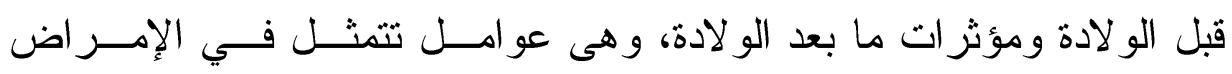

$$
\begin{aligned}
& \text { و الحو ادث و الإصابات: } \\
& \text { 1- الأمر اض: والإن وذه الإمر اض هي: }
\end{aligned}
$$

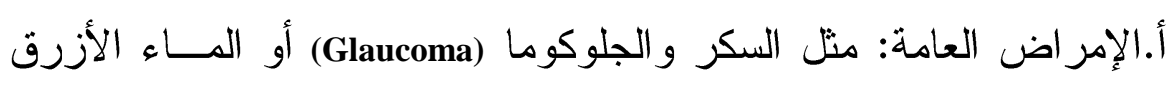
وهو ينتج عن زيادة الضغط داخل مقلة العين وتحدث بشكل مفاجئ. ب.الأمر اض المعدية: منها (الرمد الصديدي- الرمد الحبيبي).

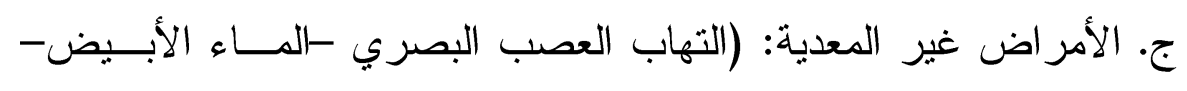
التلبف).

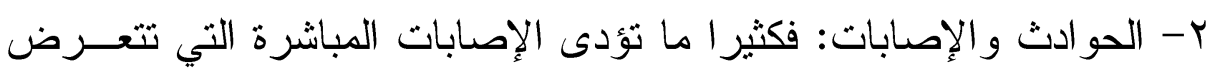

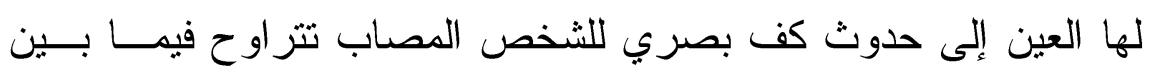

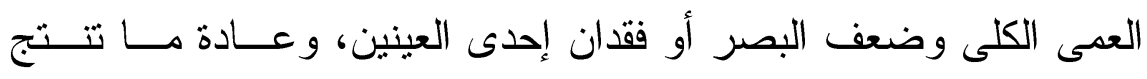

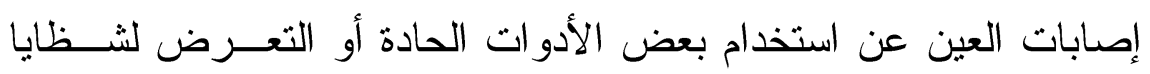

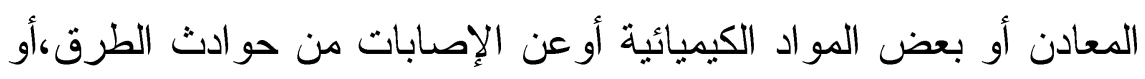

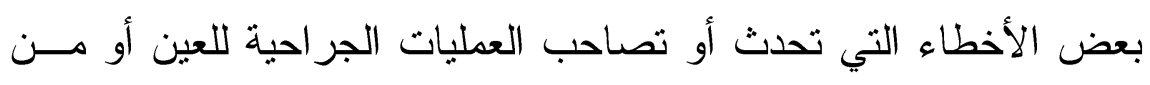

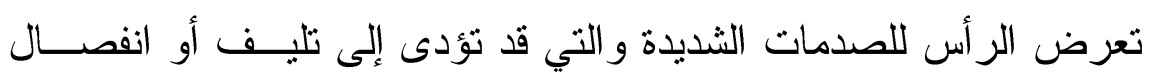

$$
\text { - تصنيف كف البصية أو تلف العصب البصري. }
$$

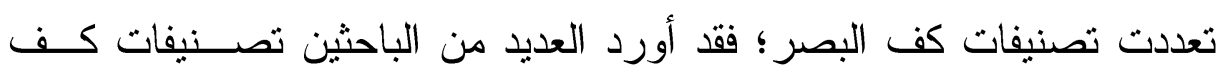

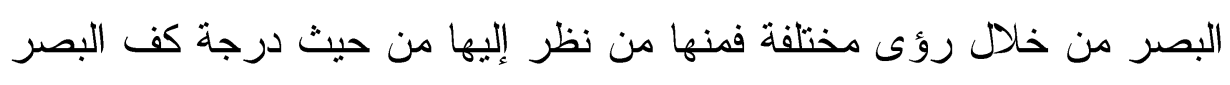

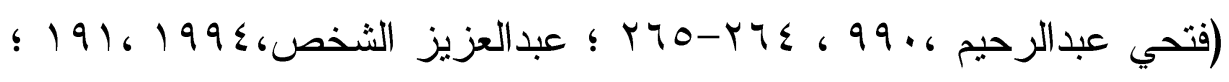

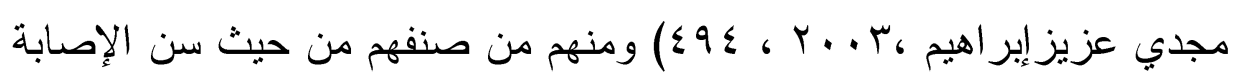




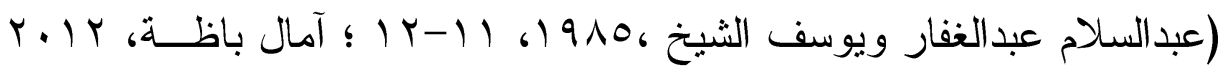

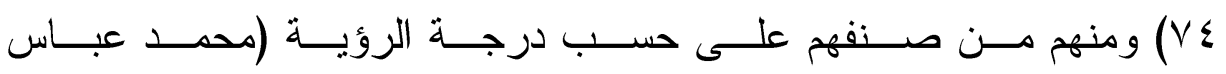

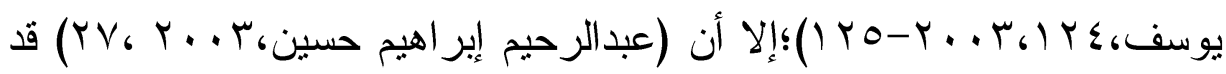
لخص التصنيف فيما يلي: مصدر التشخيص: لغوى (اعمي -أكمهـ-ضرير - عاجز - مكفــوف)، طبــي نفسي، كف هستيري، عمى عقلي، و عمى لفظي. سبب الإصابة: ور اثثة - نفسية -غير محدودة - نشريحية - بيئية. درجة الإصابة: كف كلى - إيصار جزئي - كف جزئي. زمن الإصابة: و لادية - إصابة مكتسبة (مبكرة متأخرة) تأثير الإصابة: اقتصادي - مهني - اجتماعي - تزبوي الإدية مستقبل الإصابة: دائمة - مؤقتة.

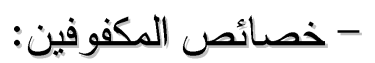

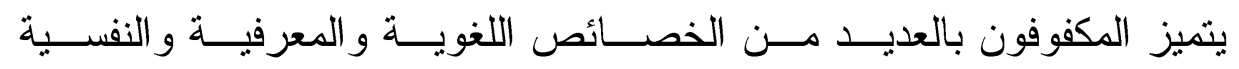
و الاجتماعية يمكن استعر اضها على النحو التالي: بلعيز - الخصائص اللغوية:

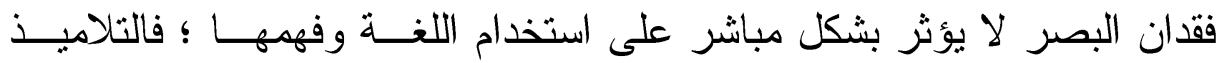

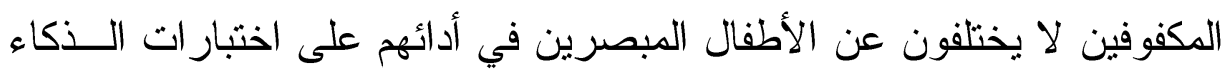
اللفظية، فهم يستطيعون سماع اللغة ولديهر دافع أكبر لاستخدامها لأنها تعتبـــر

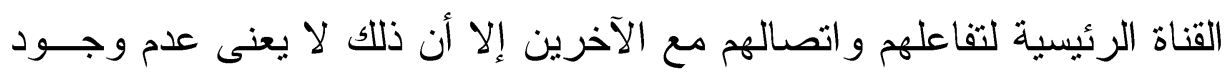

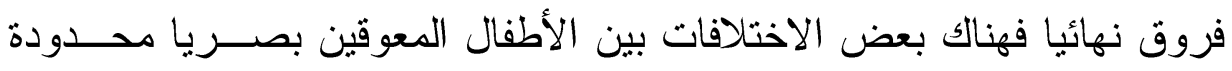
،نتيجة لفقدانهم الخبرات البصرية، كما أنهم يميلون في استخدامها إلى التركيز

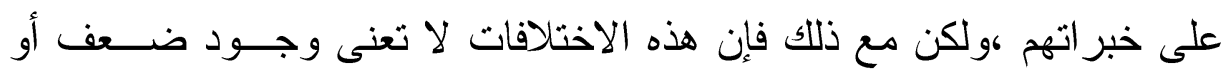

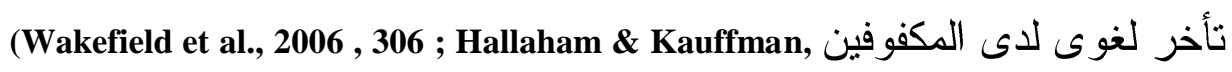
.(1991,308) 
لذا فالمكفوفون لا يختلفون عن المبصرين فيما يتعلق بالقدرة علــى الــتعلم

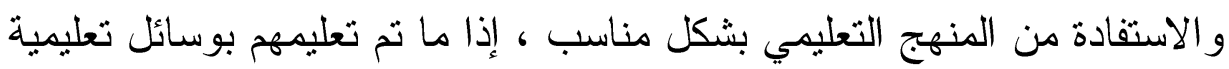

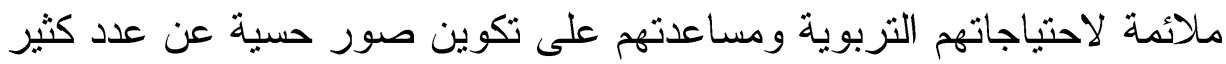

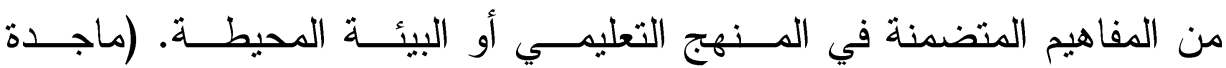

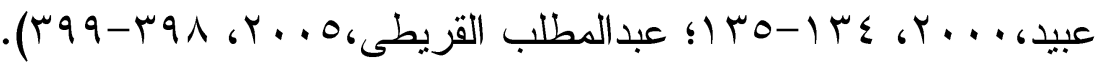
- الخصائص العقلية و المعرفية:

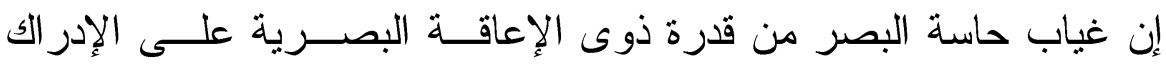

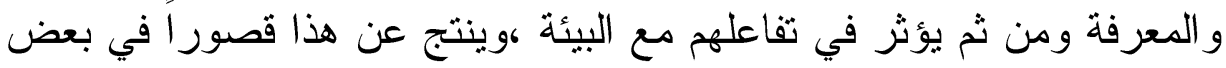

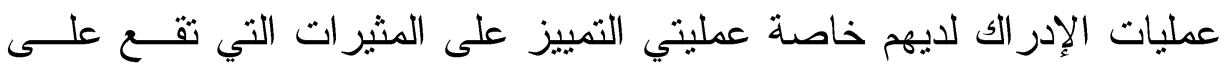

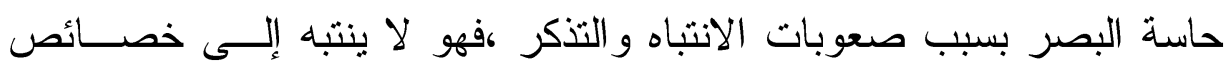

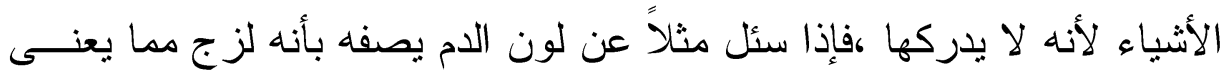

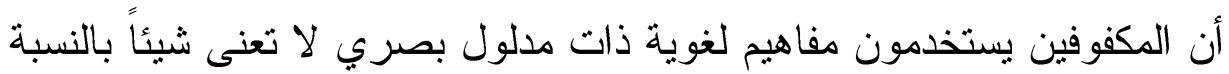

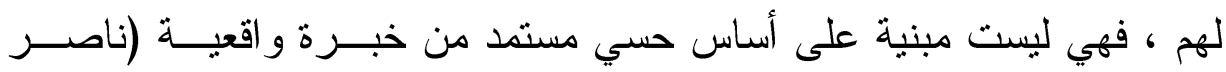

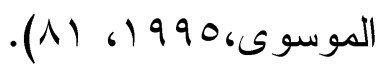

فلم توجد فروق ذات دلالة إحصائية بين المكفوفين وأقر انهم المبصرين من

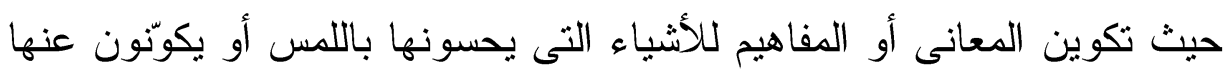

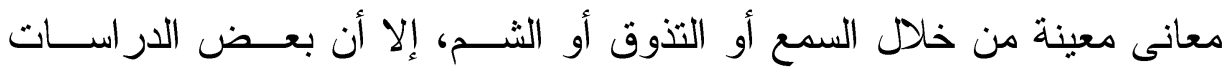

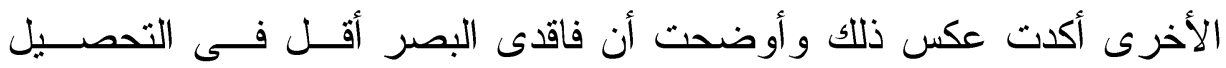

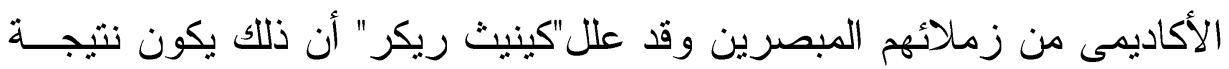

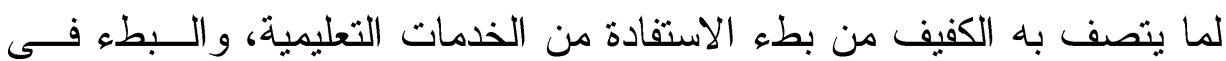

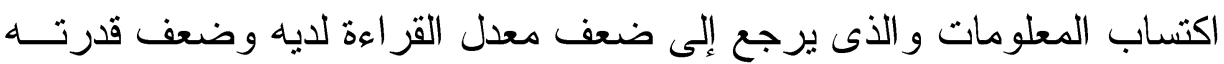

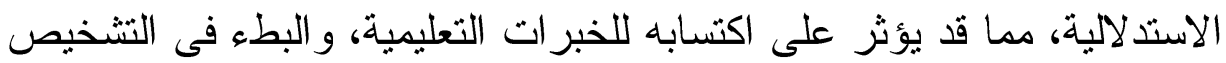
للأشياء وتتكوين مفاهيم ومعانى عنها (Feely et al., 2007 (44). أي أنهر لا يختلفون عن المبصرين فيما يتعلق بالقدرة على التعلم والاستفادة من المنهج التعليمي بشكل مناسب إذا ما تم تعليمه بأساليب تدريسية ووســائل 
ملائمة لاحتباجاتهم التربوية ومساعدتهم على تكوين صور حسية عن كثير من

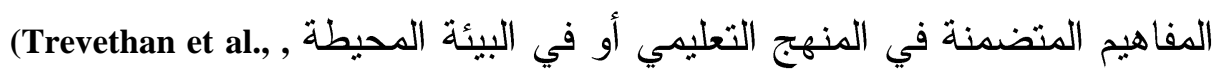
$.2007,491)$ -الخصائص الاجتماعية و الانفعالية:

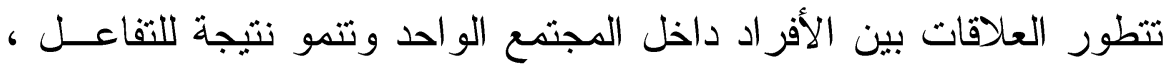

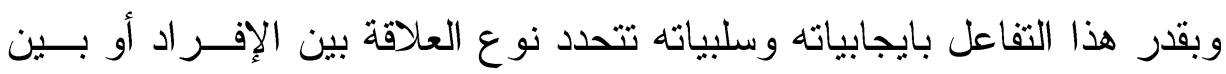

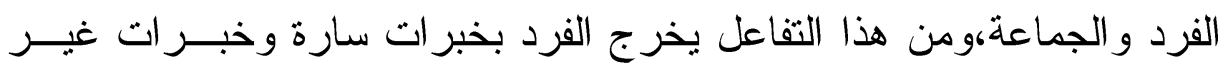

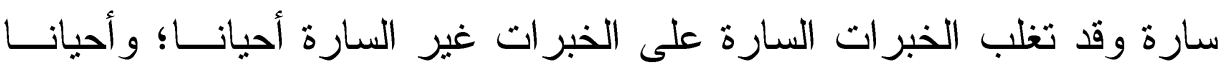

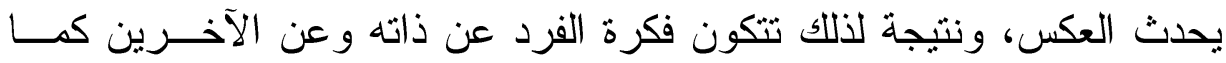
تتتكل سماته الاجتماعية والانفعالية،إذا الذي يحدد خصائص التصد الفرد الاجتماعية

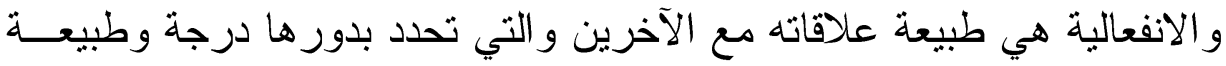

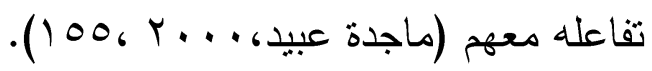
فالشخص الكفيف سرعان ما يشعر بأنه في معزل عن الجماعة مما يترتب

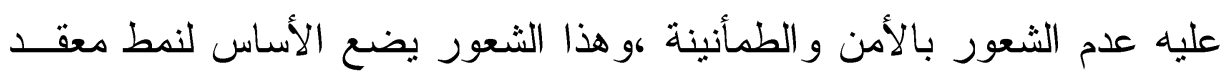

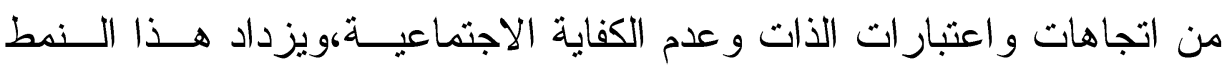

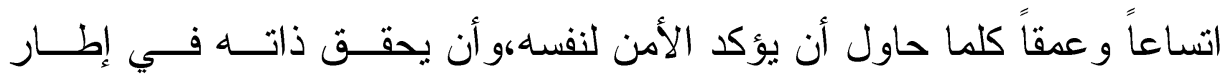
الجماعة،وفى كثير من الأحيان يو اجه عقبات بالغة لتعلم الثقة في البيئة المحيطة

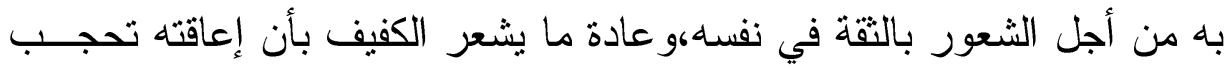

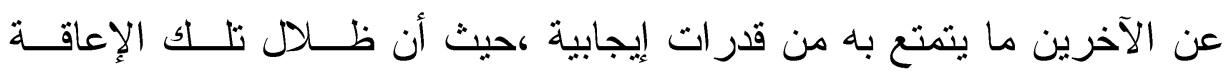

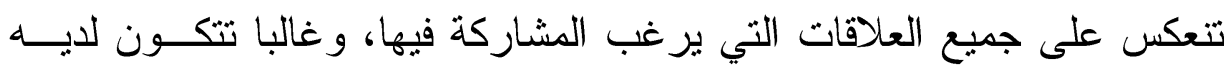

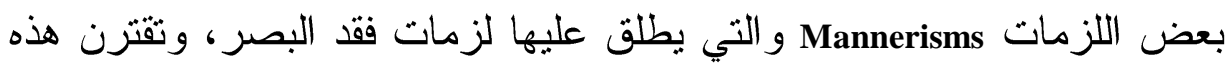

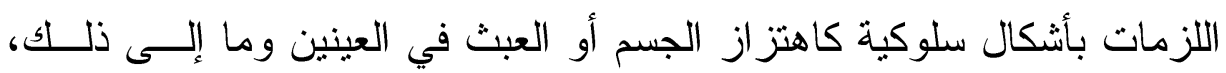
ويبدو أن مثل هذه الإشكال السلوكية تتميز بالثبوت وتكون خالية من أب معنى التى لإن

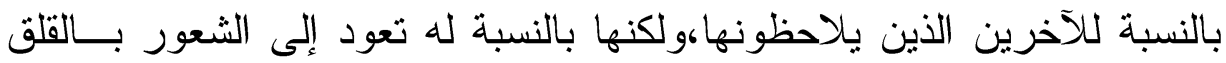

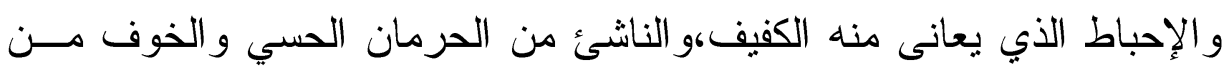


Kennedy, (المجهول و عدم الشعور بالأمن، و التي تسهم في زيادة التوتز النفسى .$(1997,65$

ولقد أجريت العديد من البحوث و الدراسات حول الخصـــائص الاجتماعيــة و الانفعالية للمكفوفين،و أجمع الكثير منها على أن بعض المكفوفين يعانون مسـن المشاكل الاجتماعية و الانفعالية ،وأن مرجع هذه المشاكل هو القصور البصري من ناحية، وردود فعل الآخرين نحو هذا القصور من ناحية أخرى ،لذلك فــانْ

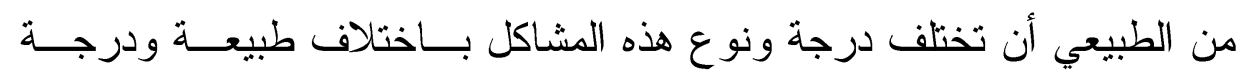

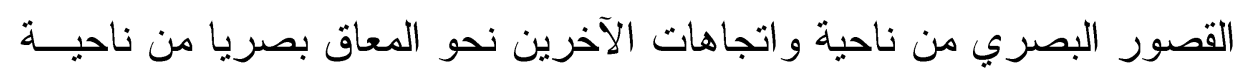

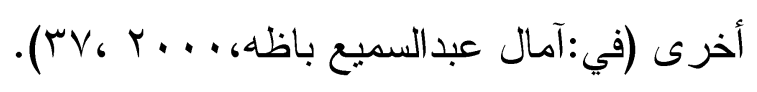

ومن أهم أنو اع الاضطر ابات الانفعالية التي يعانى منها بعض المكفوفين:

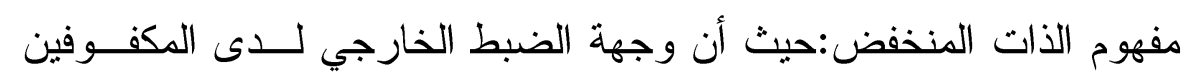

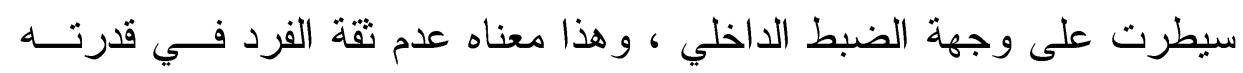
الذاتية ، و اعتماده على الآخرين. السلوك العصابى: من أبرز مظاهرما قد يعانيه بعض الأفر اد المكفوفين مــن الأن القلق و الحساسية الز ائدة و الاكتئاب و التوتر .

الخضوع: تعنى التبعية و الاعتماد على الغير وطلب المساعدة من الآخرين.

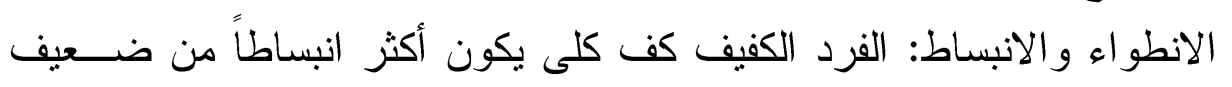
البصر الذي يعانى من الانطواء و القلق و التوثز بسبب شعوره بتهديد الكف الكلى له.

العدوانية: خاصة السلوك العدواني اللفظي ، كما يوجه بعضهه عدوانــهـ إلـىى الذات بسبب شعوره بالإحباط أو الفشل.

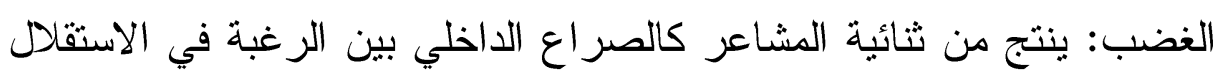
و اضطر اره للاعتماد على الآخرين. 


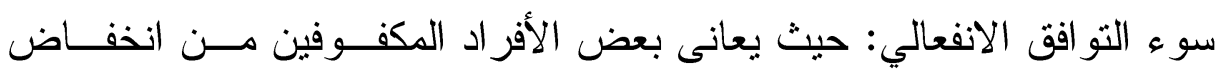

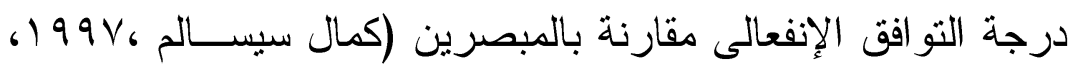

$$
\text { .(^૭-VY }
$$

كذللك قد يظهر الكفيف صعوبة في التعلق خوفاً من الغرباء، قصــور فـي التئي

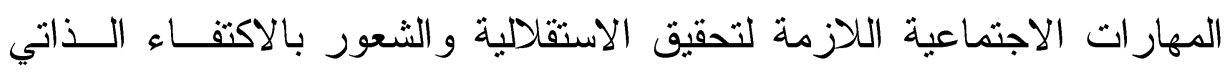

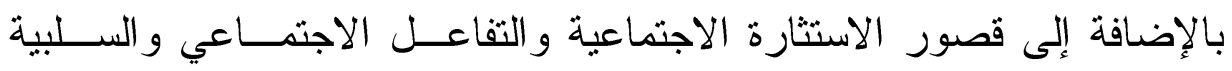

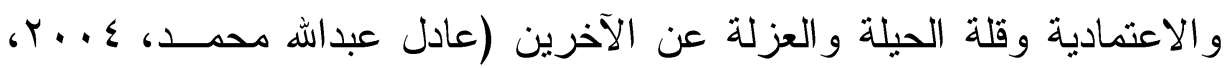

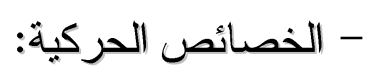

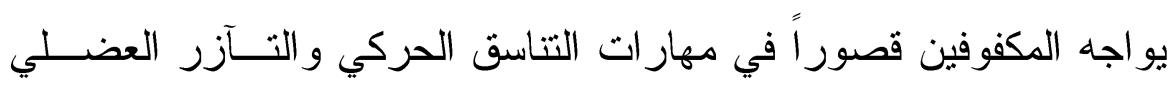
نتيجة لمحدودية فرص النشاط الحركي المتاح من ناحية ونتيجة للحرمان مسن فئن

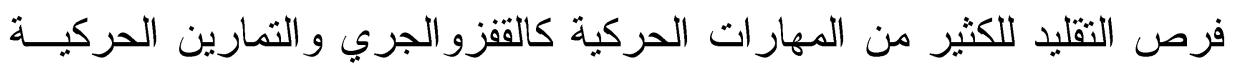

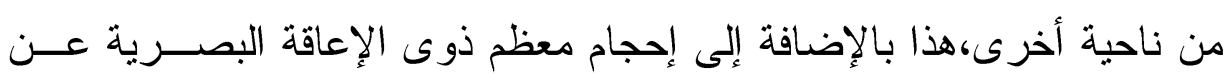

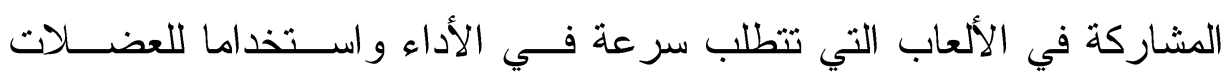
.(O'Connell et al., 2006,471$)$

ويرجع القصور في المهار ات الحركية لدى المكفوفين إلى عـدة عوامـلـل

$$
\text { رئيسية:- }
$$

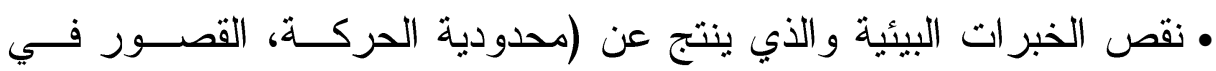

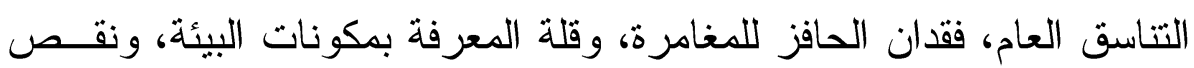
في المفاهيم و العلاقات المكانية التي يستخدمها المبصرون). • قلة الفرص المتاحة للتدريب على المهار ات الحركية.

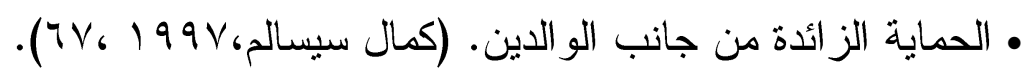

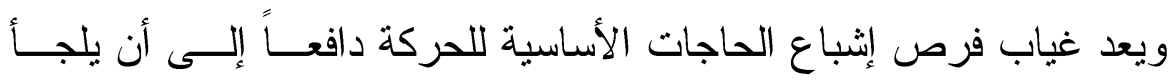
الأطفال المكفوفين للبحث عن الرضى من خلال قيامهم بنشاطات جسمية نمطية

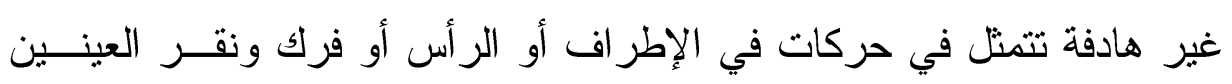




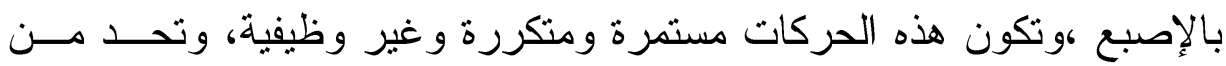

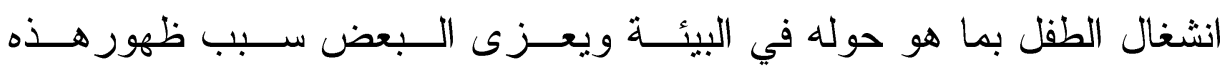
السلوكيات النمطية إلى النقص في الإثارة الحسية المناسبة ومحدودية الحركـــة فئة

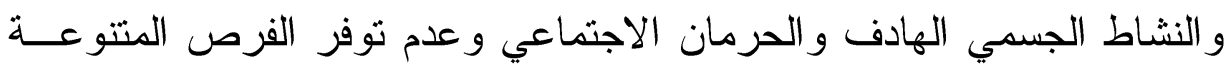

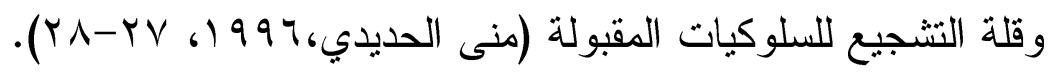
[ب] أساليب مو اجهة الضغوط: COPING WITH STRESS

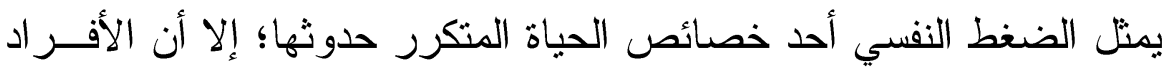

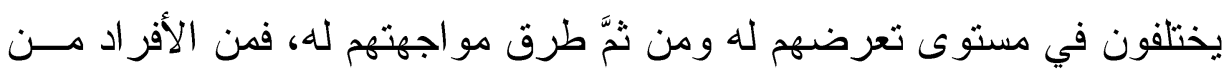

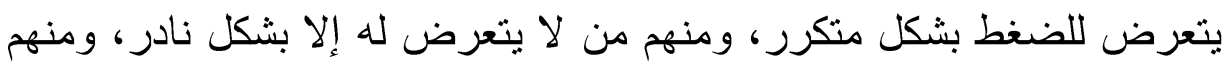

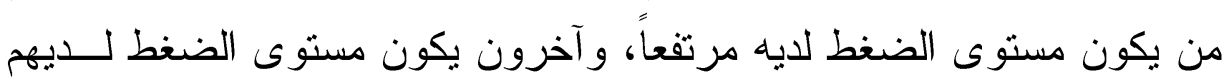
منخفضاً ومحدوداً.

ويشير سويت وآخرون Sweet, et al. (999 1) إلى أن هناك علاقة تفاعليــة

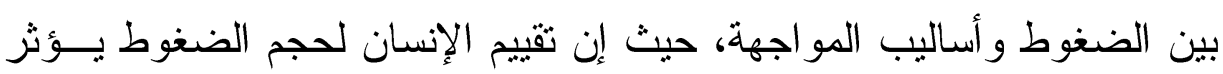

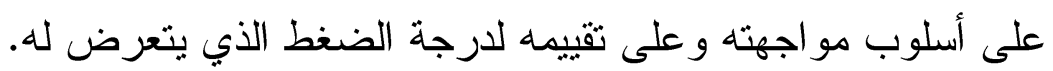

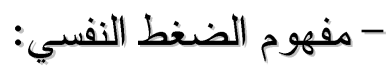

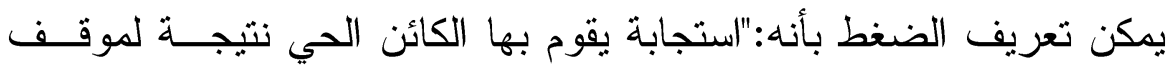

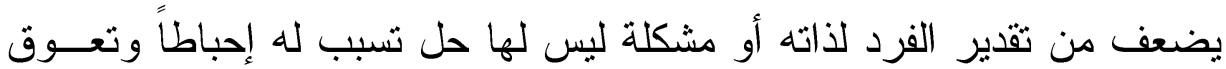

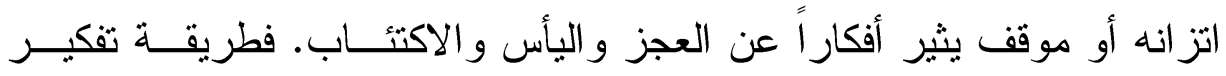
و إدر الك وتفسير الفرد للموقف ذات تأثير على انفعاله وسلوكه، تحدد مدى تأثره بالمو اقف التي يواجهها، بل المتغيرات المعرفية هي التي تحدد تأثيره بالموقف

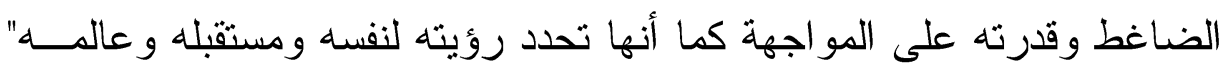
(Beck, 1976: 37)

يعرف بأنه: "حالة معرفية دينامية تشير إلى عدم التوازن بــين متطلبــات

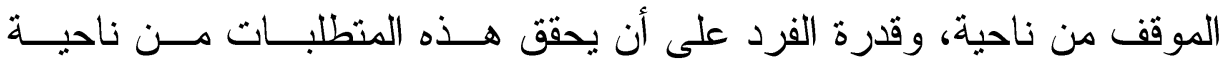
أخرى.وفي هذا الإطار،فان الضغوط لا تكمن في الفرد أو في المثيرات البيئية

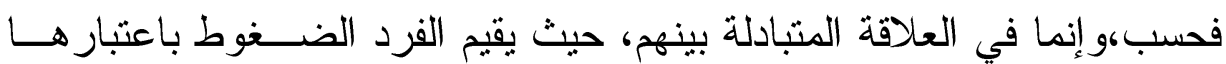


(Long \& Cox, 2000: "أحداثاً شاقة تفوق قدرته على مو اجهتها مما يهدر صحتها

أو بأنه"حالة يعانيها الفرد حين يو اجه بطلب ملح فوق حدود اســنطاعته، أو حين يقع في موقف صراع حاد،أو خجل شديد. إضافة إلى هذا،إذا ثرتب على الضغوط النفية حدوث أذى حقيقي فإن الفرد يصبح محبطاً،وحتى إن لم يحدث ضرر حقيقي ومباشر على الفرد فهو يعيش حالة من الشعور بالتهديد" (فــرج

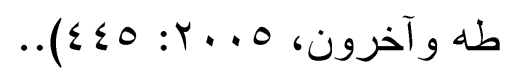

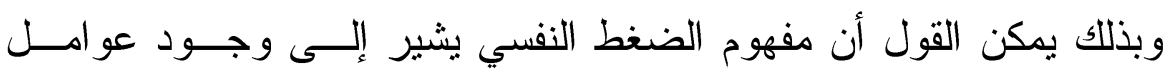

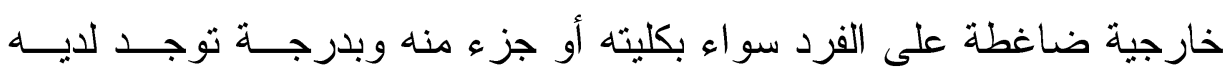

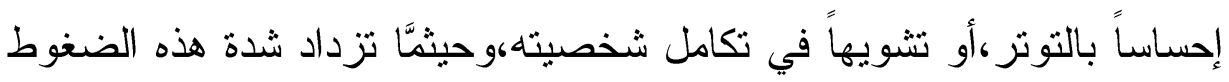
فإن ذلك قد يفقد الفرد قدرته على التوازن،ويغير نمط سلوكه عما هو فيه إلـى نمط جديد، وللضغوط النفسية آثار ها على الجهاز البدني و النفسي للفرد. - استر اتيجيات و أساليب مو اجهة الضغوط ولهو النفية: يمكن تعريف مو اجهة الضغوط بأنها:"مجهودات معرفية سلوكية مســتمرة يقوم بها الفرد للتعامل مع متطلبات أي موقف يتم إدر اكه وتقييمه على أنه يفوق طاقة الفرد ويمثل موقفاً ضاغطاً"(Lazarus \& Folkman, 1984: 14-15). وقدم كو هين Cohen( 99 ( ) مجموعة دن الاستر اتيجيات المعرفية لمو اجهة ضغوط الحياة، منها: التفكير العقلاني: يتجه الفرد فيها إلى التفكير للبحث عـن مصـــادر القلـق ت و أسبابه المرتبطة بالضغوط. الإنكار : وهي عملية يسعى الفرد من خلالها إلى إنكار الضغوط ومصادر ها بالتجاهل و الانغلاق وكأنها لم تحدث. التخيل: يتجه الفرد فيها إلى التفكير في المستقبل وتخيل ما قد يحدث. حل المشكلة: وهو نشاط معرفي يتجه الفرد من خلاله إلى استخدام أفكـــار جديدة ومبتكرة لمو اجهة الضخوط. 
صلابة الثخصية وعلافتها بأساليب مواجهة الضغوط النفسية لاى المراهقين المكفوفين ـ. سهام عبد الغفور

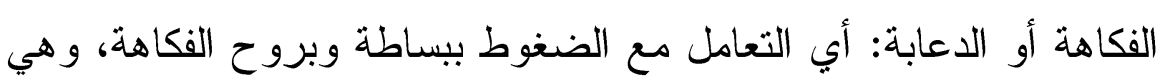
تدل على الانفعالات الإيجابية أثناء المواجهة.

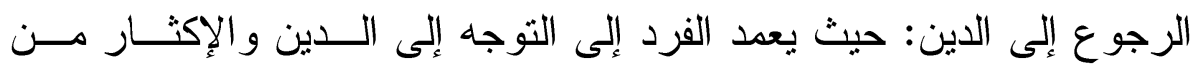

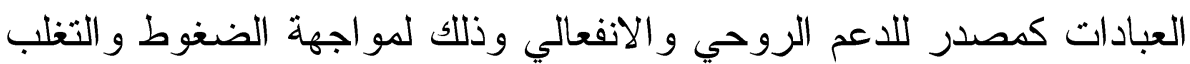
عليها.

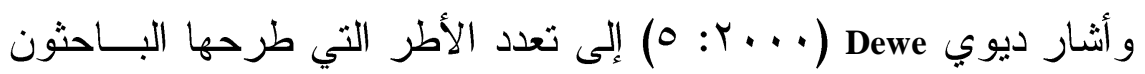

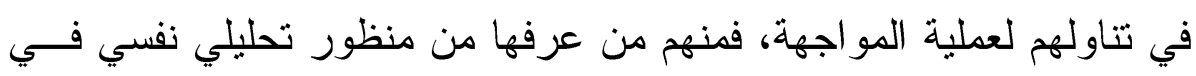

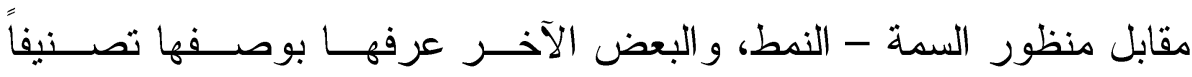
لاستر اتيجيات محددة.

في حين تشيرو ايت White (.... إلى إلى وجود العديد من أساليب مو اجهة الضغوط النفسية الذاتية و المهنية، منها: أسلوب المواجهة الانفعالية: يقوم هذا الأسلوب على المبالغة في الانفعالات لمو اجهة التهديد، والتي منها القلق و التوتر و الخوف و هي تعتمد على التفكير التهول السلبي.

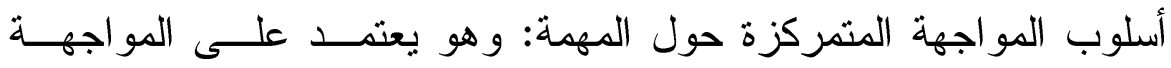
الإيجابية النشطة للضغوط النفسية، وهي بذلك ترنكز إلى التفكير الإيجـابي التئي حول المهمة وكيفية التعامل معها.

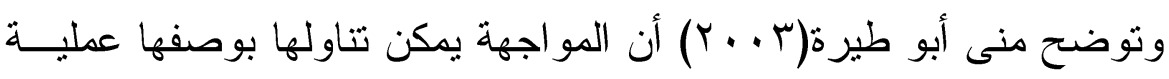

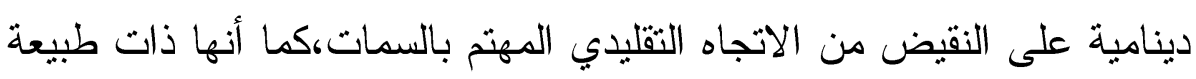

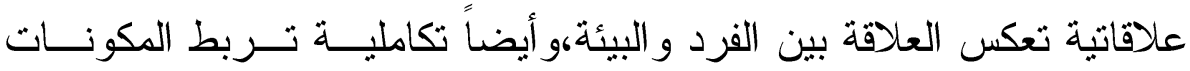

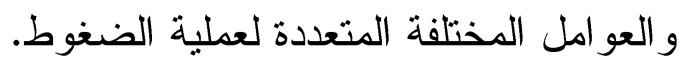

الار واسات السابقة

تعرض الباحثة الدراسات السابقة مقسمةً إياها إلي محورين:

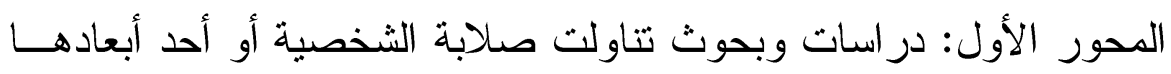

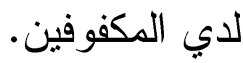


كثف سمير عبدالغفار(1999 ) عن درجة التوافق الشخصي والاجتمــاعي

لاي بعض الأطفال المعاقين بصــريا وضــــاف البصـــر مقارنـــة بالأطفــال

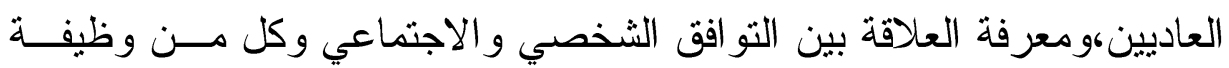

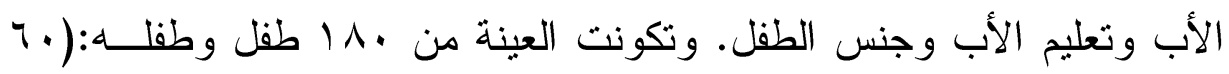

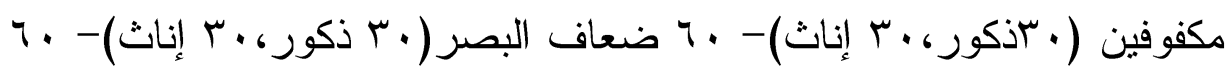

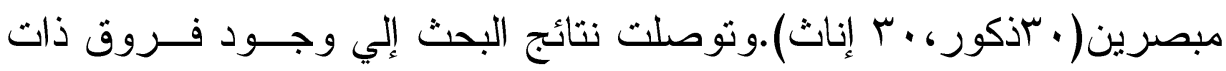

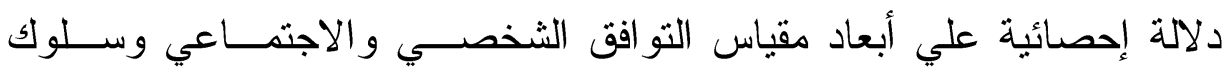

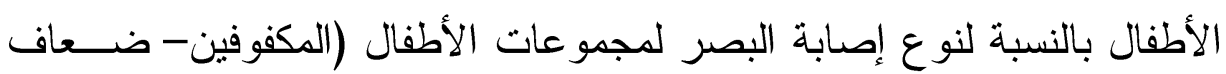

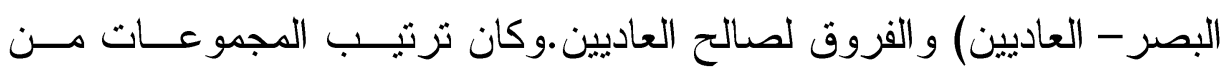

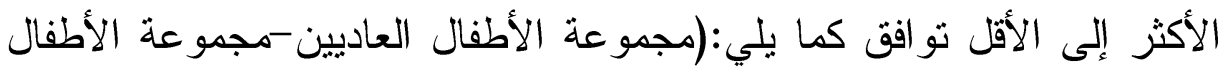

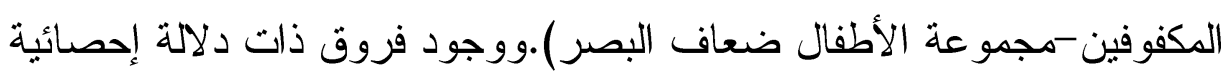

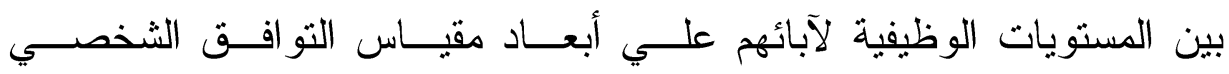
و الاجتماعي وسلوك الأطفال (المكفوفين - ضعاف البصر - العاديين) و الفـــرق

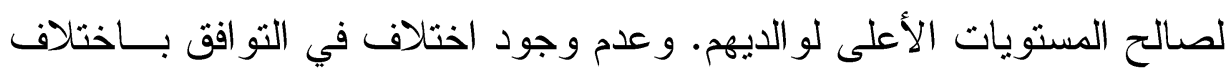
السن كما انه لا يوجد اختلاف في التوافق باختلاف الجنس.

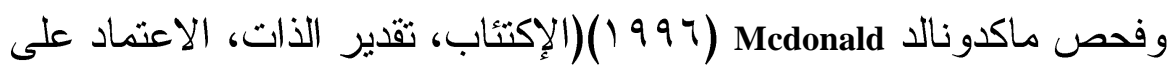

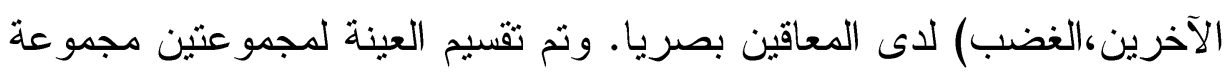
المعاقين بصريا"و لاديا"، ومجموعة من المعاقين بصريا"إعاقة مكتسبة"، كما نم

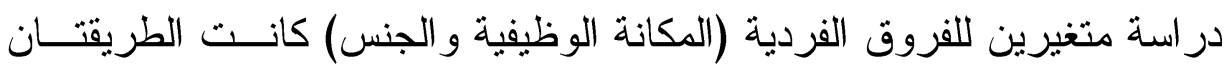

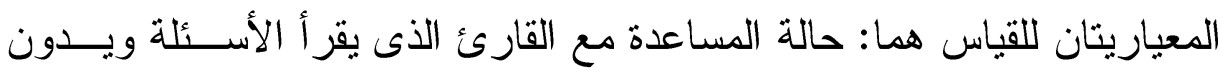

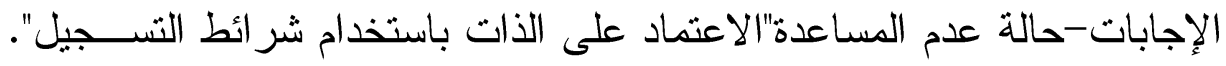

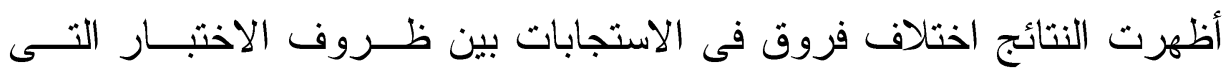

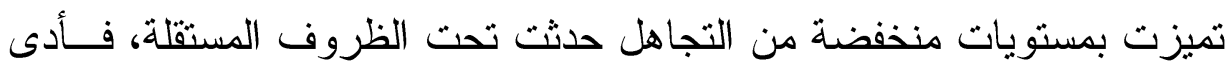
ذلك إلى أن المشاركين الذين تم مساعدتهم بقارئ ربما شعرو ا بإحساس هائــلـل

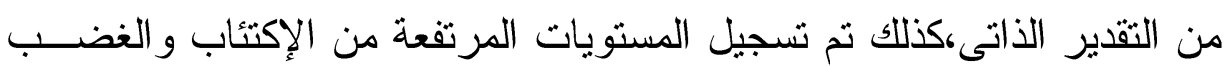


تحت ظروف القياس المستقلة. لذلك فإن حالة كف البصر "مكتسبة أم و لاديــة"

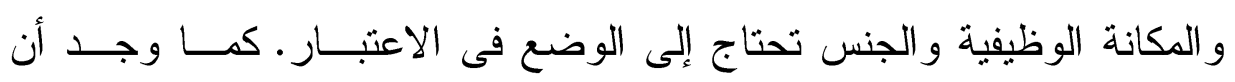

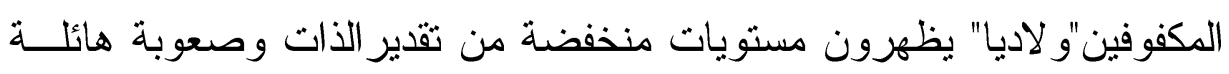

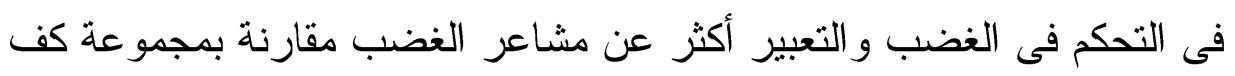

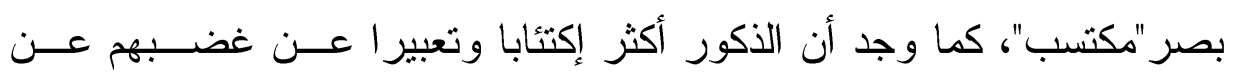

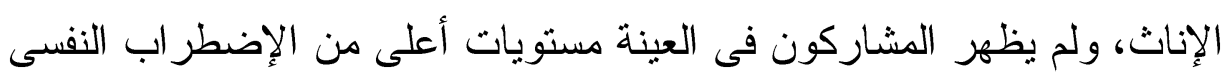

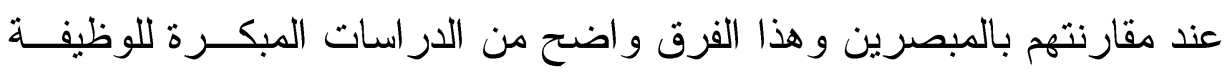
النفسية.

وبحث عماد مخيمر(997 (19) علاقة الصلابة النفسـية و المســاندة الاجتماعيــة بضغوط الحياة و أعر اض الاكتئاب لدىه V طالب و \9 طالبة جامعيين و استخدم

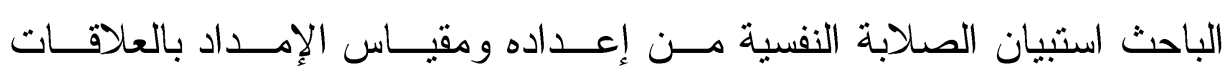

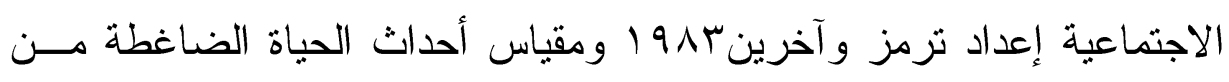

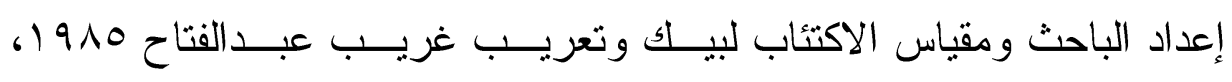

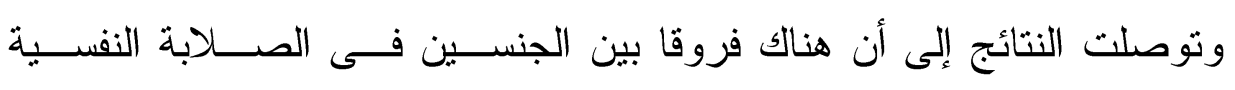

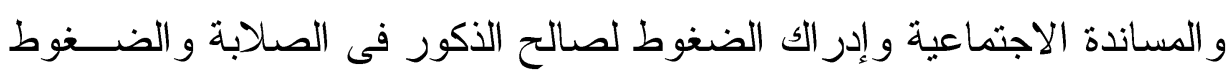

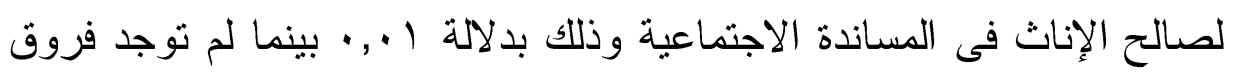

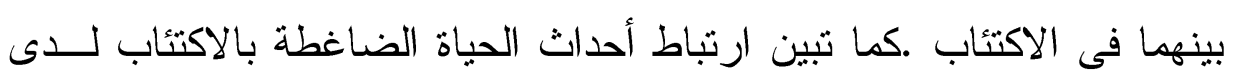
الأكور و الإناث.

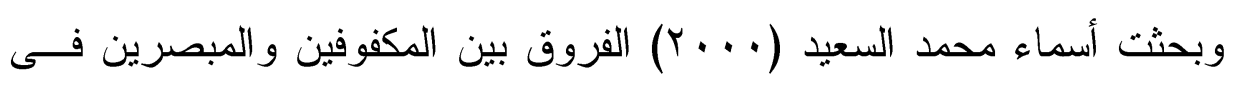
أبعاد مصدر الضبط، وتأثير الجنس وكف البصر على أبعاد مصدر الضــبط.

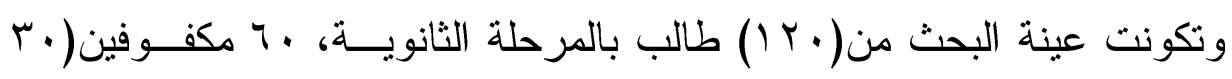

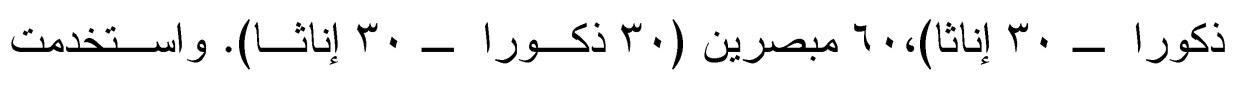

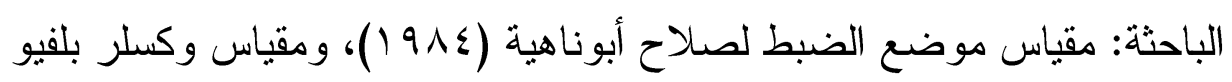

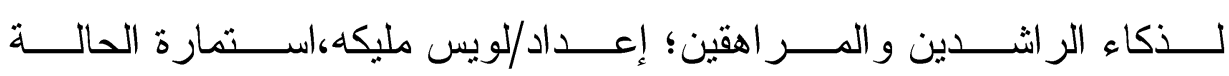

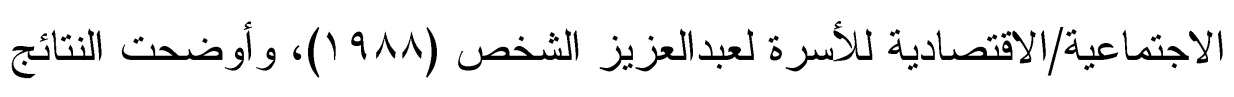


وجود فروق دالة إحصائيا بين المبصرين و المكفوفين فى أحد مكونات ضــبط

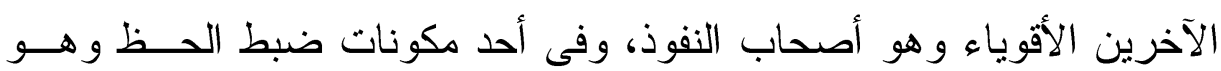

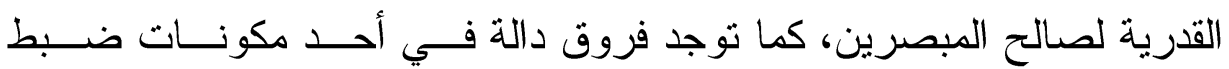

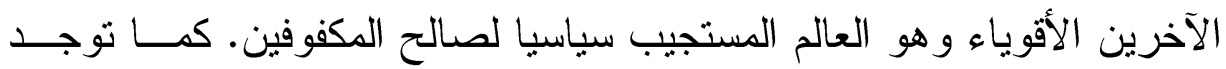

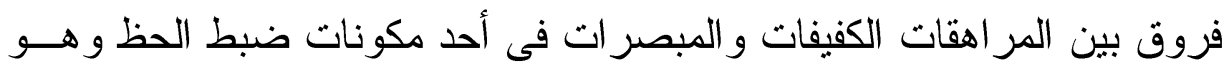
القدرة لصالح المبصر ات وكذللك فروق بـين الـــكور المبصــرين والإنـاث

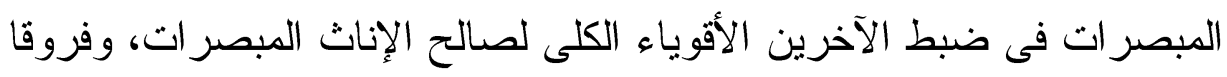

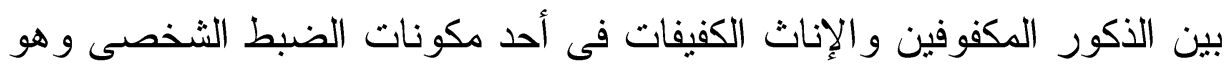
الاخلية العامة لصالح الإناث.

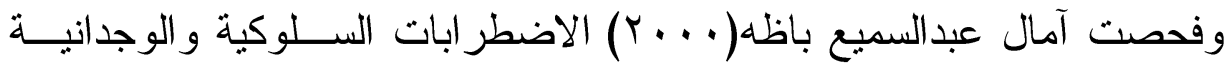

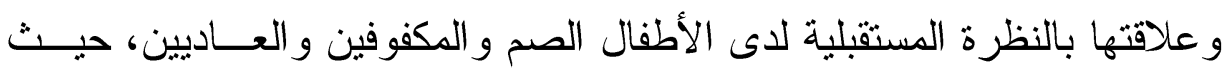

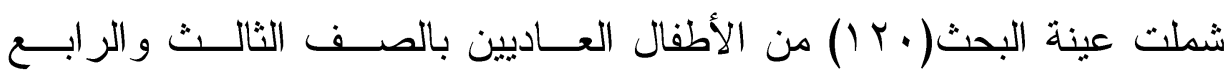

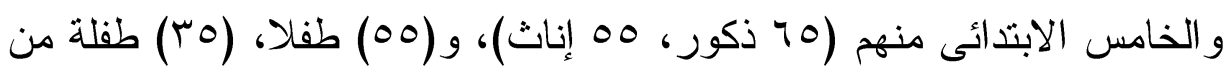

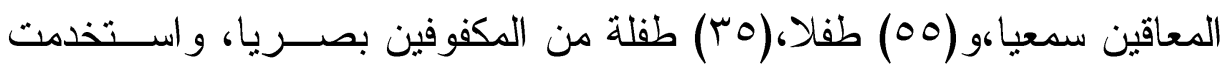

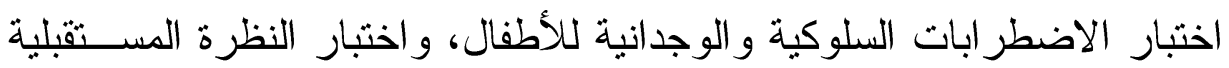

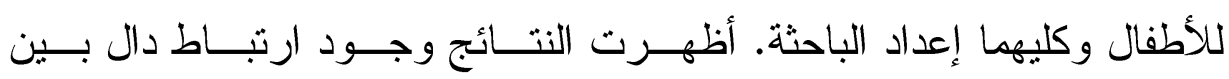
الاضطر ابات السلوكية و الوجدانية و النظرة للمستقبل لدى البنين الصم، و البنات

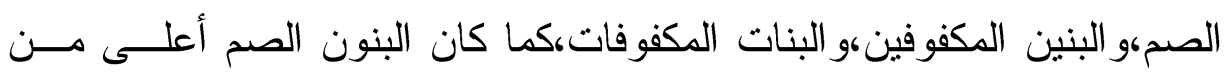

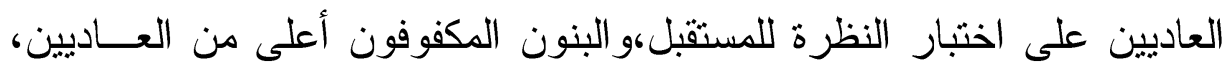

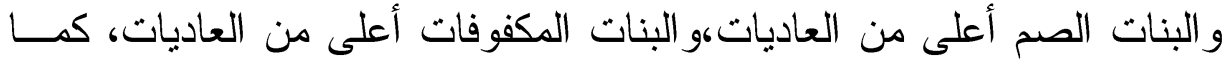

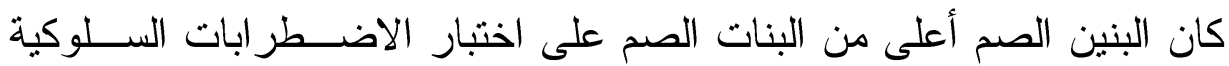

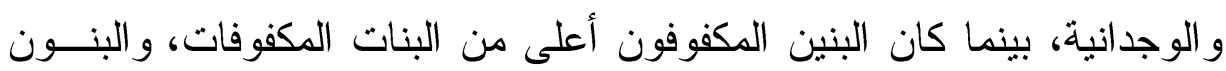
العاديون أعلى من البنات العاديات،كما كان البنون الصم أعلى من البنات الصم الصن 


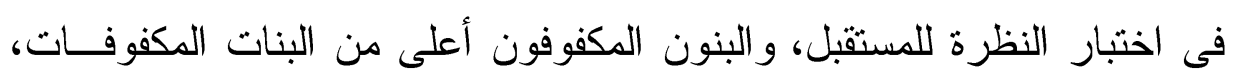

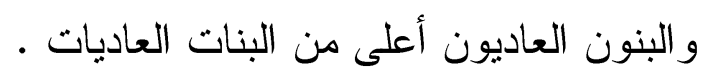

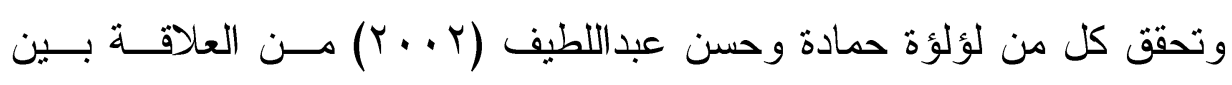

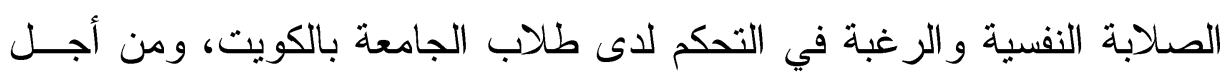

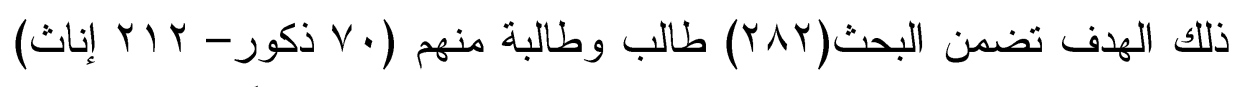

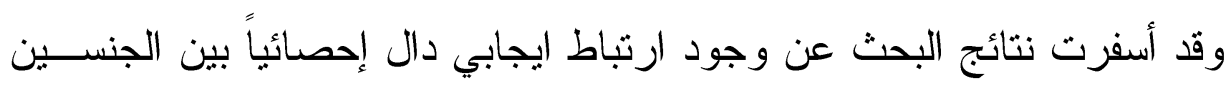

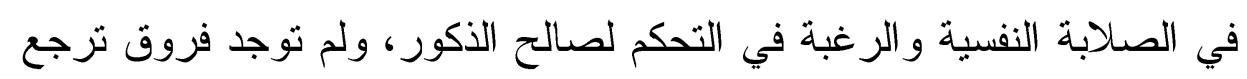

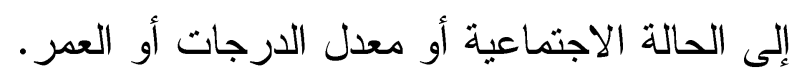

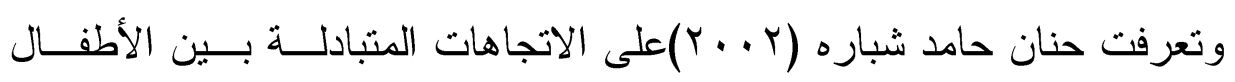

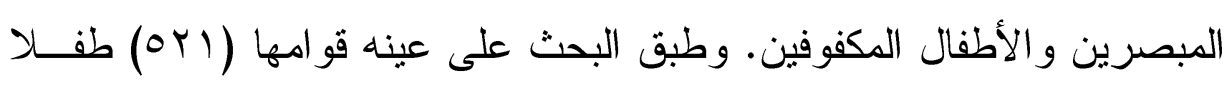
من تلاميذ المرحلتين الابتدائية و الإعدادية المعزولين و المدمجين وقسمت البهن العينة

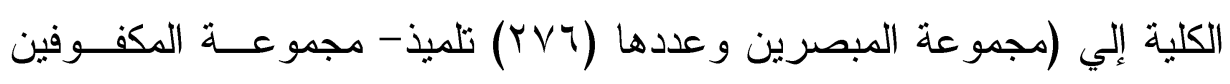

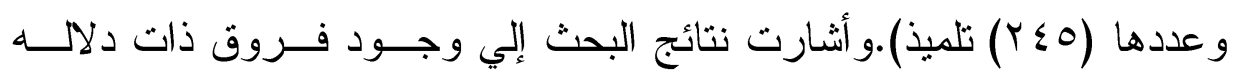

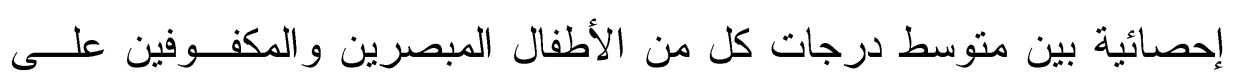

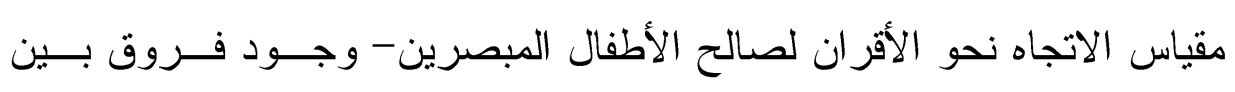

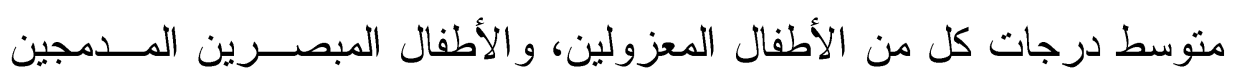

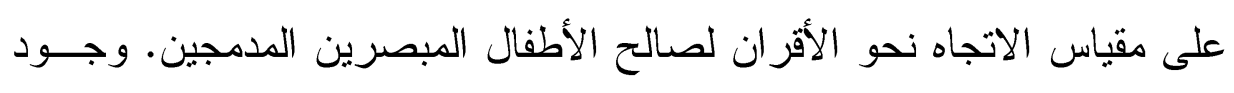

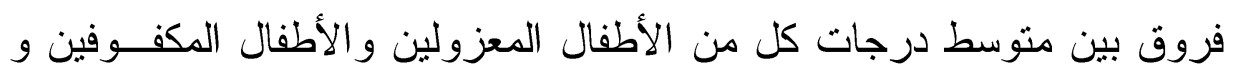

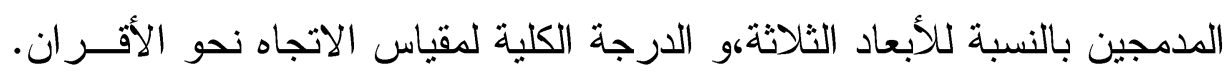
وجود فروق بين منوسط درجات كل من الذكور و الإناث على مقياس الاتجــاه نحو الأقران). ودرست شفاء أحمد حسين(Y. . . . الأمل وعلاقته بأحداث الحيــاة الضـــاغطة

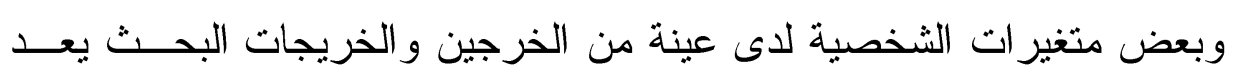

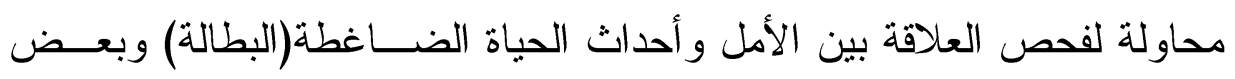




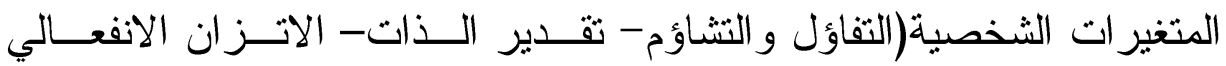
الصلابة النفسية - مركز الضبط) وكذللك أثار ها السلبية التي تؤثر على سلامة

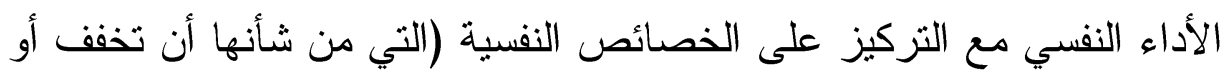
تقي أو تعدل من التأثثر الضار لضغوط لحياة والإحساس بفقدان الأمل و اليأس. وتوصلت أهم نتائج البحث الى وجود علاقة ارتباطية ودالة إحصائيا بين الأمل و أحداث الحياة الضاغطة. وتعرف أحمد محمد الدبور (Y. . . (Y) على مستويات الصلابة النفسية في ضوء متغيري النوع ومدة الإعاقة ومدي فعالية برنامج ارشادي لتتمية ورفع مستوي

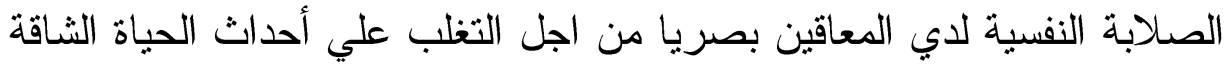

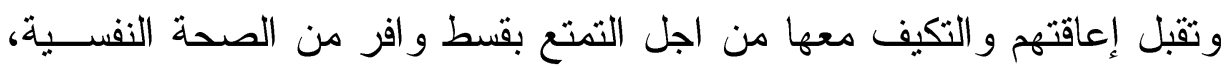

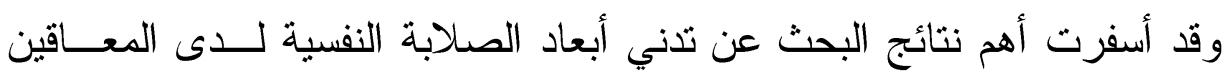

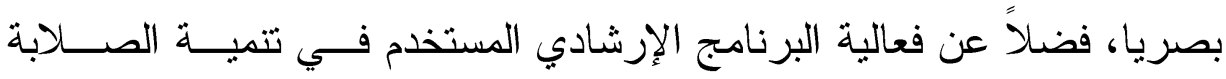
النفسية لاي المعاقين بصريا.

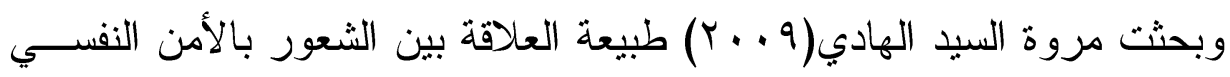

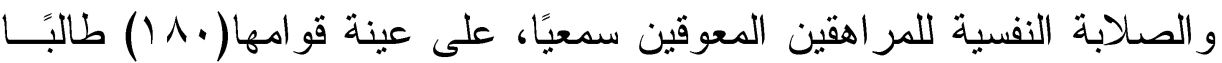
وطالبة بالمرحلة الإعدادية والثانوية بمعهد الأمل للصم وضعاف السمع بمدينة

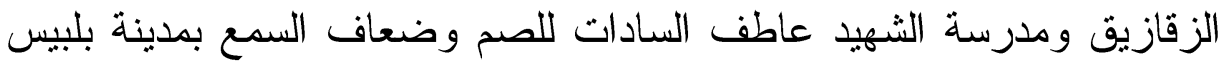

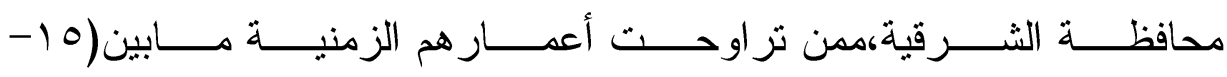

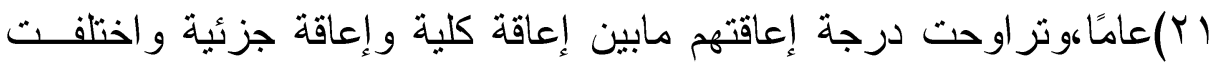

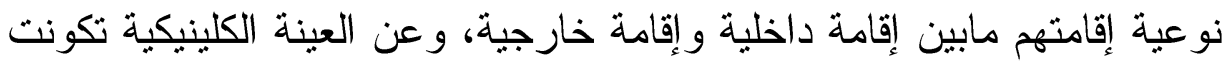

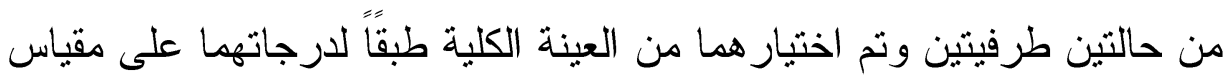

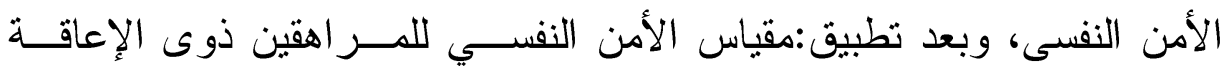

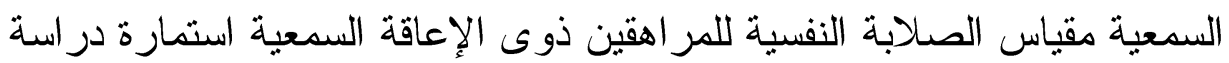

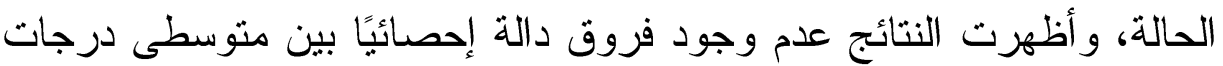


المر اهقين ذوى الإعاقة السمعية فى الأمن النفسى طبقًا للجنس فيما عداوجـــود

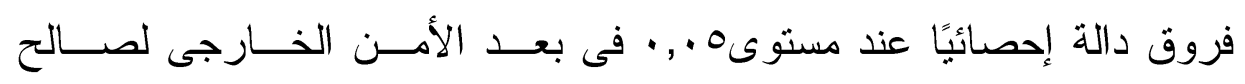

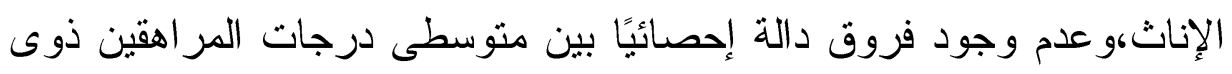

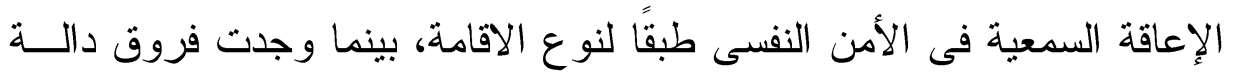

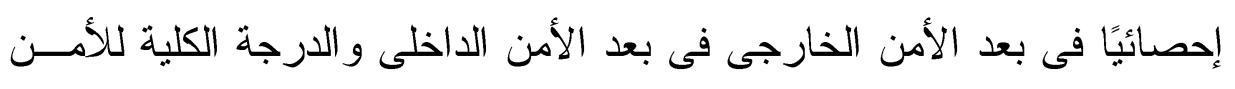

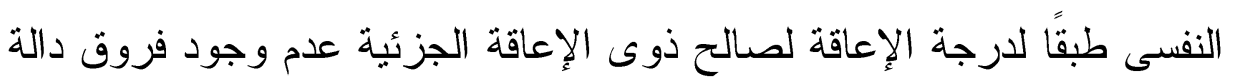

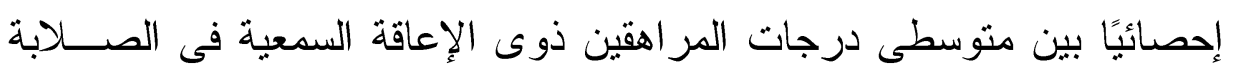

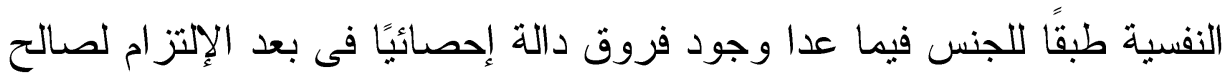

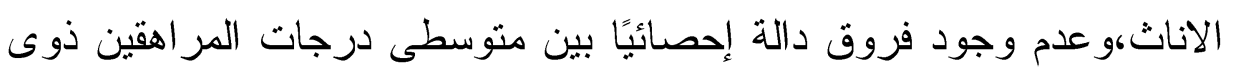

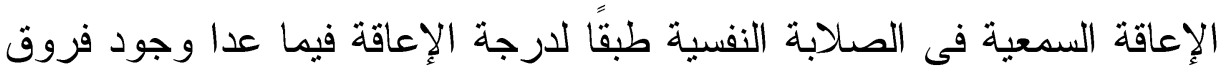

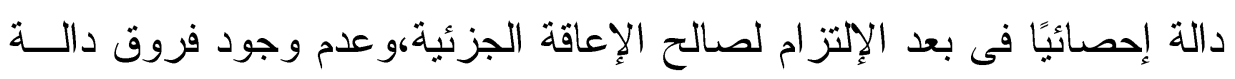

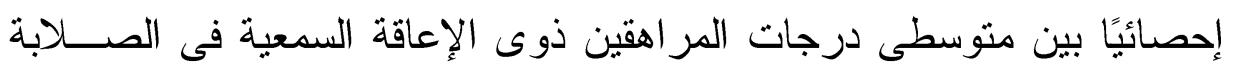

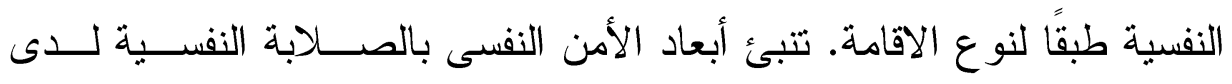

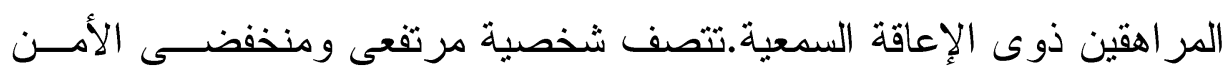
النفسى بديناميات شخصية مميزة لهما.

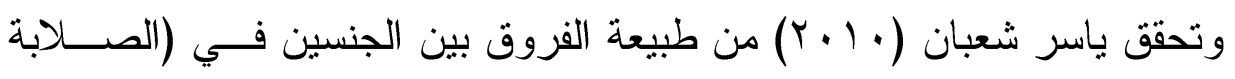

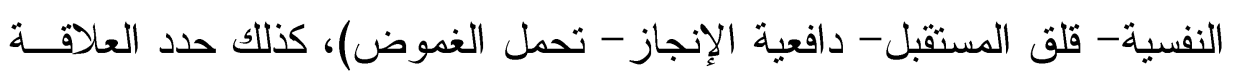
بين المتغير ات النفسية (الصلابة النفسية- قلق المســتقبل - دافعيــة الإنجــاز)

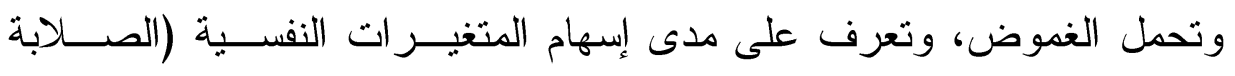

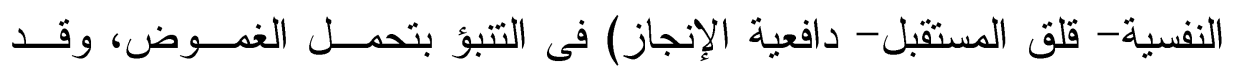
توصلت نتائج البحث إلى وجود فرق دال إحصائيًا بين الطلاب و الطالبات فـي في لئي

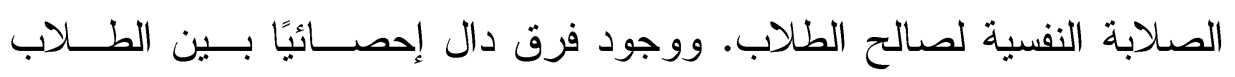

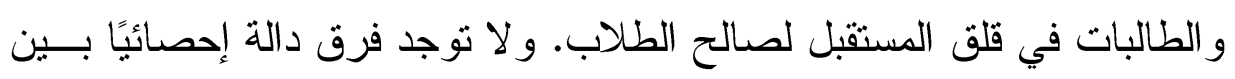

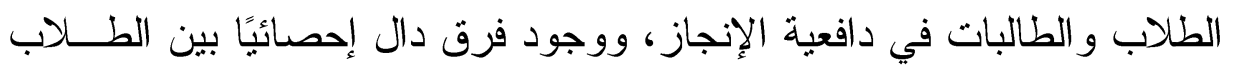


و الطالبات في تحمل الغموض لصالح الطلاب، ووجود علاقة دالة موجبة بـين الصلابة النفسية وتحمل الغموض.ووجود علاقة دالة سالبة بين قلق المســنقبل وتحمل الغموض لدى عينة البحث.ووجود علاقة دالة موجبة بين دافعية الإنجاز

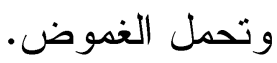

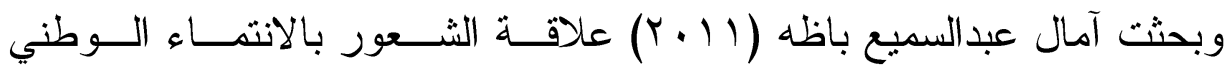

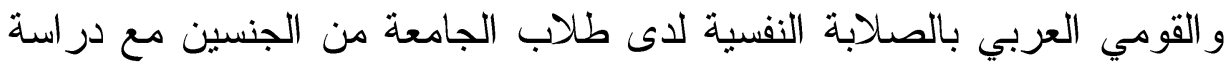

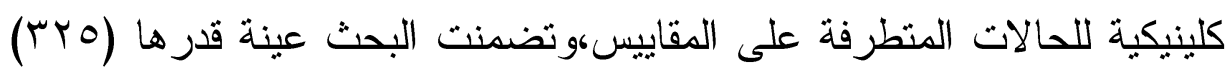

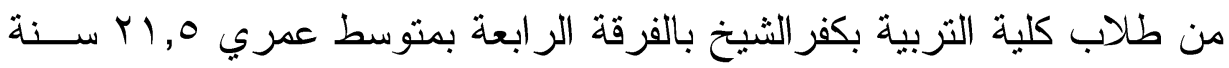

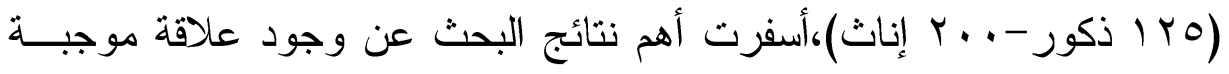
ودالة بين الشعور بالانتماء الوطني و القومي العربي مــع الصـــابة النفســـية و أبعادها.

المحور الثاني: دراسات وبحوث تتاولت الضغوط النفسية لدي المكفوفين.

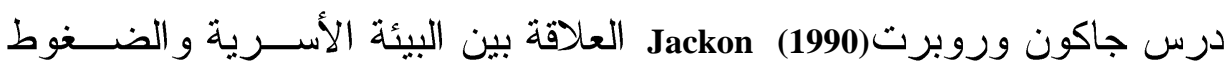

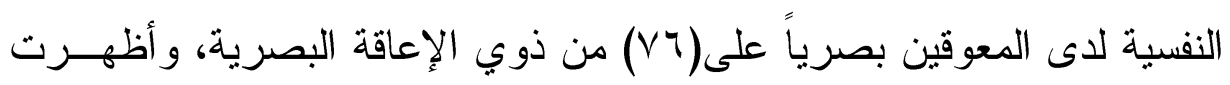

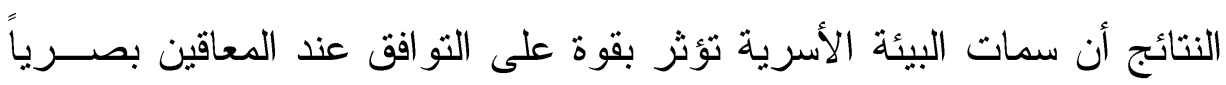

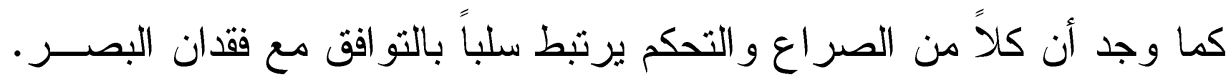

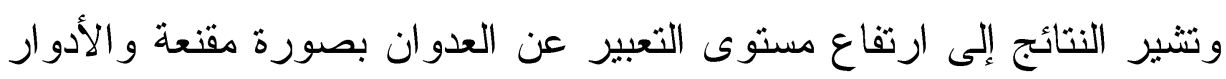
الأسرية القاسية ترتبط بارتفاع مستوى الضغوط النفسية لدى المعاقين بصــرياً وكذللك فإن زيادة الضغوط تعكس قلة التو افق مع فقدان البصر .

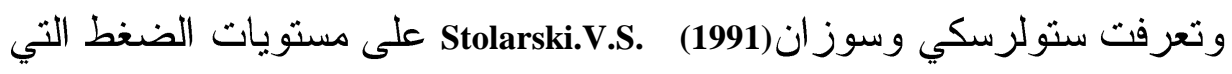
يعايشها أفر اد أسر المعاقين بصرياً والأطفال المعاقين بصرياً ومنعددي الإعاقة.

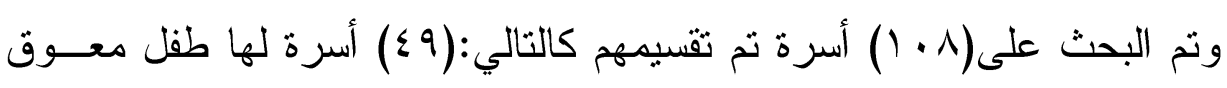

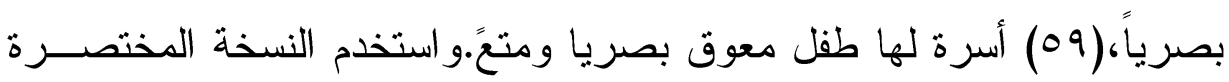

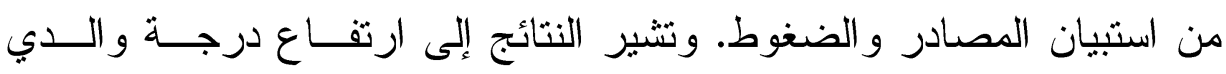
TVV 
الأطفال المعاقين بصرياً ومتعدد الإعاقة أكثر من درجة والدي الأطفال المعاقين

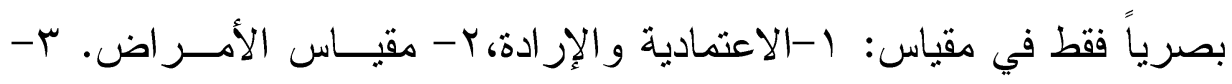

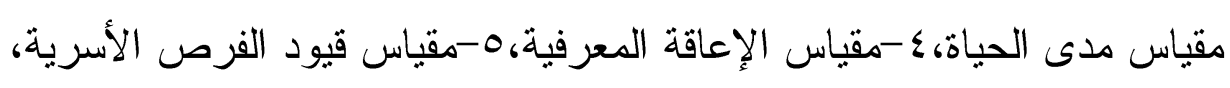

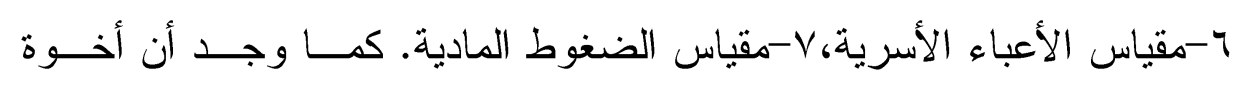
الأطفال المعوقين وذلك من العاديين يعيشون ضغوط نفسيه من الأخوة المعوقين

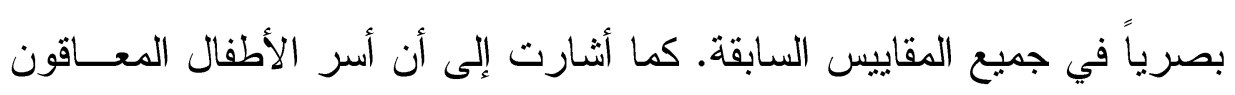
بصرياً ومتعددي الإعاقة يعيشون ضغوطاً نفسية في العديد من المجالات.

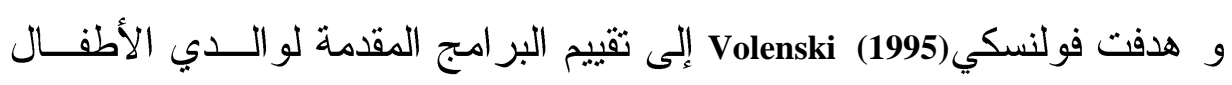
المعاقين في مرحلة ما قبل المدرسة، وقد اشتملت عينة البحث على (بآه) طفلاً

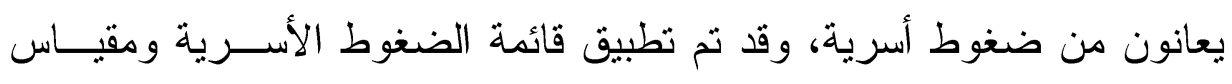

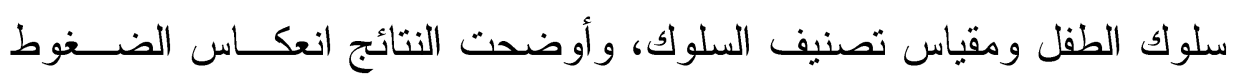

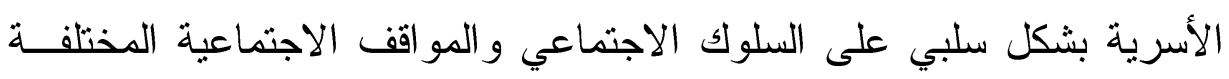

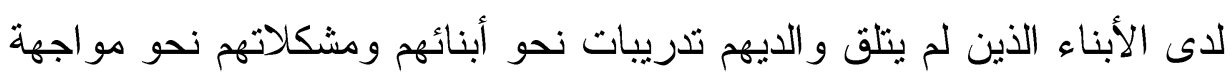
المو اقف بصورة إيجابية.

و فحصت ليسر و آخرون Leyser, et.al. الضغط و التكيف في الأسر التـي لديها أطفال بعانون من إعاقة بصرية، حيث اهنمت بدراسة الضغوط النفسـبة النية الأسرية لدى (V^) أسرة لايهه أطفال يعانون من الإعاقة البصرية ونم استخدام

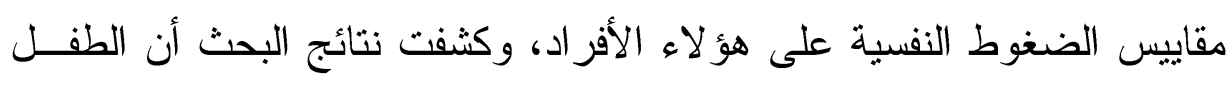

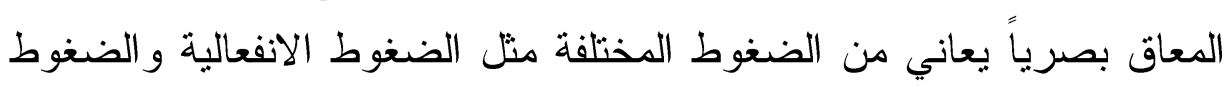
الأسرية و الضغوط المستقبلية.

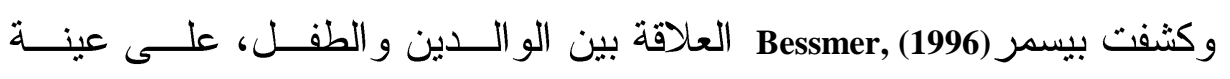

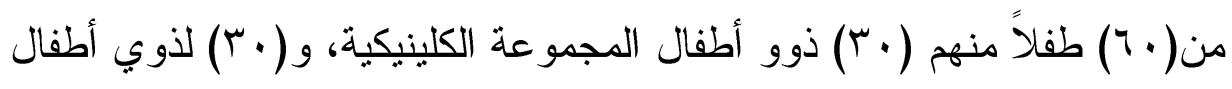
المجموعة المقارنة التي لا تعاني من مشكلة تلك العلاقة التفاعلية بين الوالدين

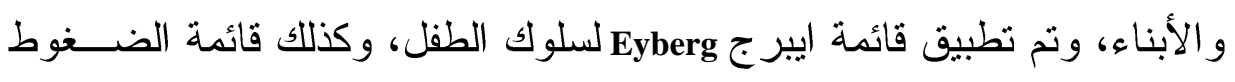


الأسرية، ومركز التحكم الو الدي وأيضـاً تصــنيف علاقــة التعامـلـ الخاصـــة

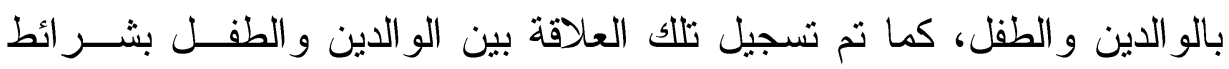

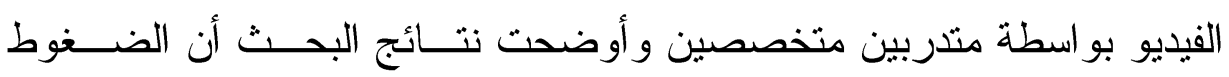
الأسرية التي يعانيها الأبناء لها أثز ها السلبي على العلاقة بين الأبناء و الآباء.

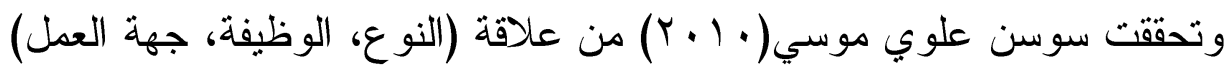

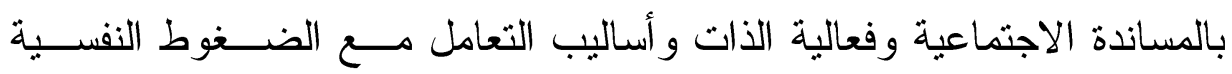

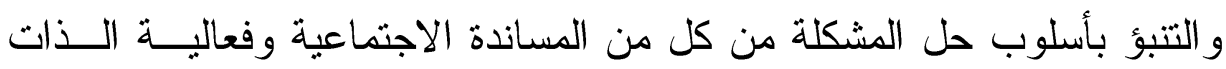
و الكثف عن بعض العوامل الدينامية الكاملة المسئولة عن ارتفاع الدرجة على بلى بلى لدهن

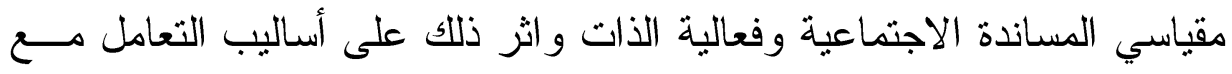

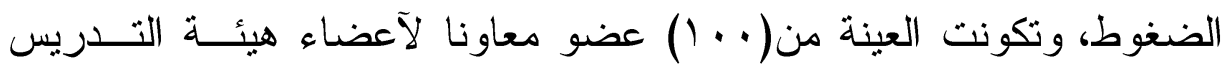

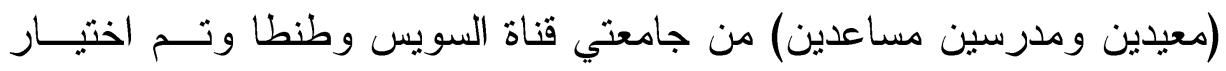

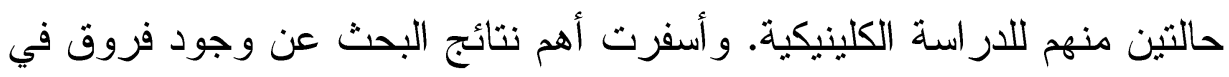

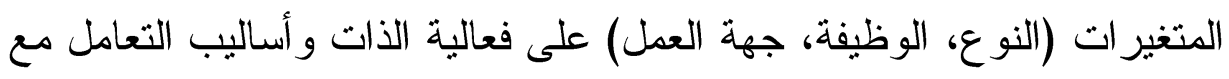

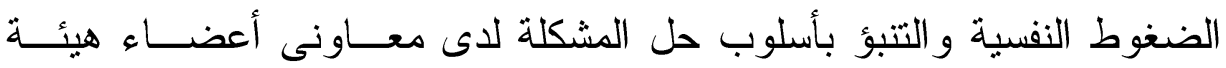

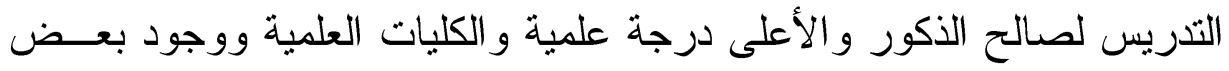

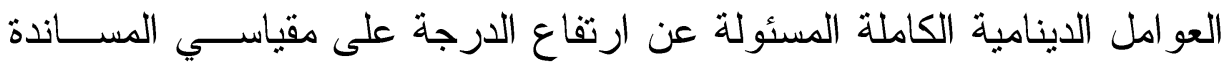

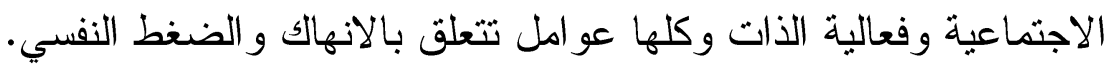
أوجه الاستفادة من الدراسات وعاله السابقة: تحديد العديد من المتغيرات التي تمنل خصائص التلاميذ المكفوفين و التي تؤثر بشكل أو بآخر على صلابتهم الثخصية وأساليب مواجهة الضغوط النفئنية.

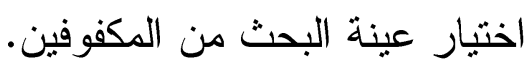
تحديد أدو ات البحث وصياغة فروض البح من البحث. فروض البحث: تتمثل فروض البحث الحالي في: 
صلابة الثخصية وعلافتها بأساليب مواجهة الضغوط النفسية لاى المراهقين المكفوفين ـ. سهام عبد الغفور

توجد علاقة دالة إحصائياً بين صلابة الشخصية وأساليب مواجهة الضــغوط النفسية لدى المر اهقين المكفوفين الذكور.

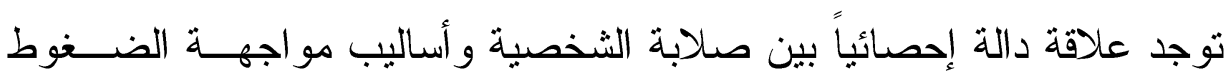
النفسية لدى المر اهقين المكفوفين الإناث.

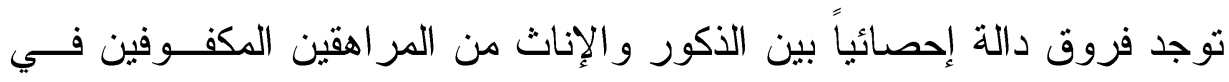
صلابة الشخصية. توجد فروق دالة إحصائياً بين الذكور والإناث من المر اهقين المكفــوفين فــي أساليب مو اجهة الضغوط لنفسية.

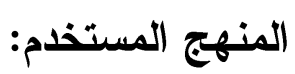
يفي البحث الحالي بمنطلبات المنهج الوصفي، وفي هذا النوع مسـن الدراســات

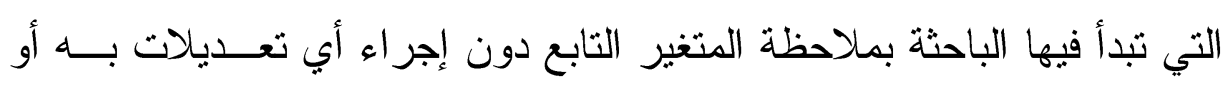
التحكم فيه. عينــة البحث فئ

تكونت عينة البحث من ( •0) من المر اهقين المكفوفين بمدرسة النور للمكفوفين بكفر الثيخ ومدرسة أم المؤمنين للمكفوفين بطنطا بمدي عمري (عن (1-1 () سنة

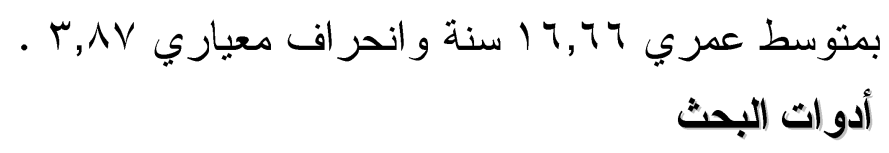

(1) مقياس صلابة الثخصية إعداد الباحثة( (1). يهدف المقياس إلى تحديد درجة صلابة الثخصية للمكفوفين. ويتكون المقياس

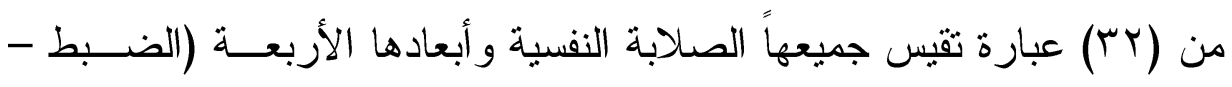

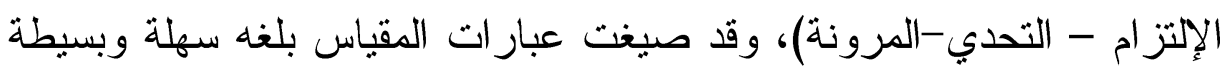

(') أنظر ملحق رقم (أ) 
وواضحة بحيث تكون الإجابة عن طريق تقدير الشخص ذاته" نوع من التقدير

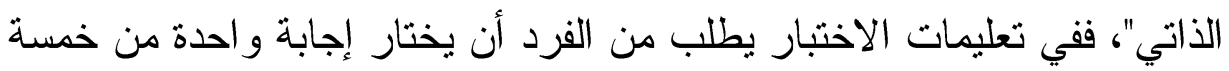

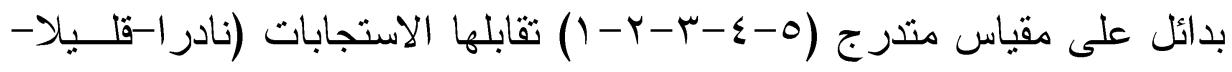
بدرجة متوسطة-كثر ا-كثير ا جدا) و العكس بالنسبة للعبار ات العكسية. وقد اطلعت الباحثة على العديد من التعريفات المختلفة للصلابة النفسية و التــي بلهي

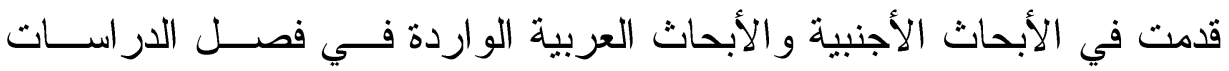
السابقة - كما سبق عرضها -. وتطرقت الباحثة للعديد من المقاييس التي تقيس التيس

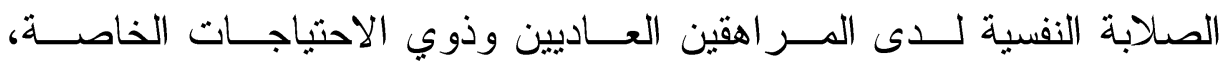

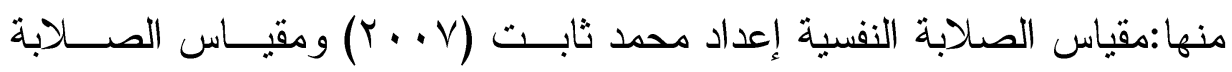

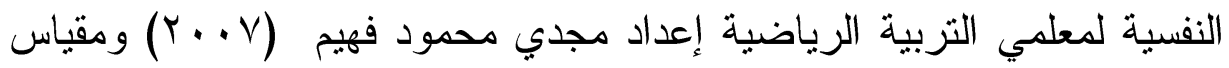

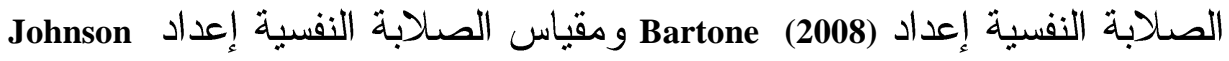
Florian et al. (1995) ومقياس الصــلابة (2004) ومقياس الصلابة النفسية إعداد

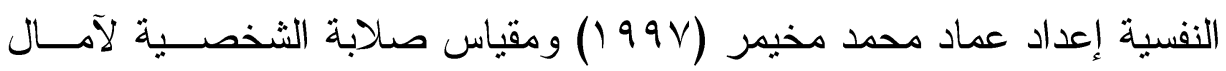
باظه (1) (1)، ومن خلال الإطار النظري و المقاييس و الدراسات السابقة التي تتاولت الصدابة النفسية، وبالإضـافة إلى عقد لقاءات مفتوحة مـــع الهـــر اهقين

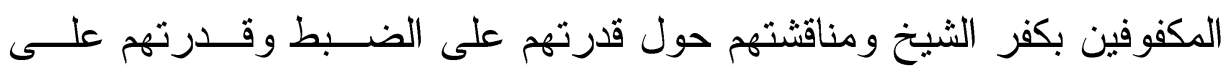

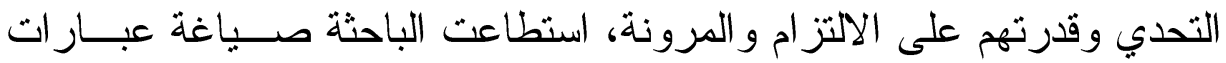

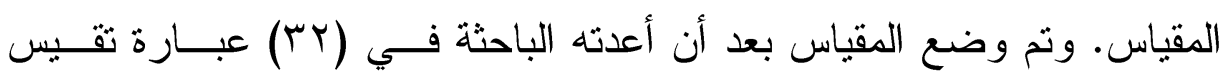

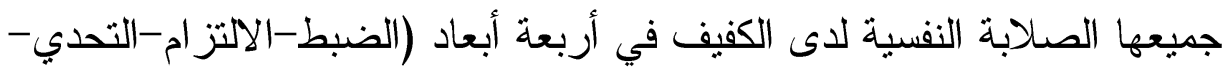

الكفاعة السيكومترية للمقياس: اختارت الباحثة عينة التقنين وتتكون من (Yo) مــن المـــر اهقين المكفــوفين بمدرسة النور بدمنهور، وقد قامت الباحثة بتقدير الدرجة الكلية للمقياس. . [أ]- - صدق المقياس: 


\section{صلابة الثخصية وعلافتها بأسائيب مواجهة الضغوط النفسية لاى المر اهقين المكفوفين د. سهام عبد الغفور}

- صدق المحكمين: تم عرض المقياس في صورته الأولية علــى (• () مسـن

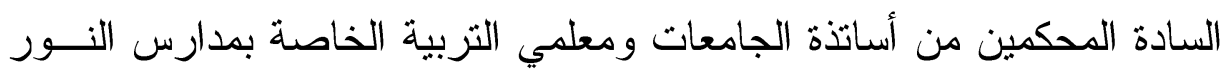
للمكفوفين، و أقروا جميعا بأن العبار ات تقيس ما وضعت من من أجل قياسل

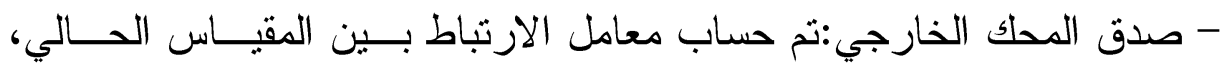

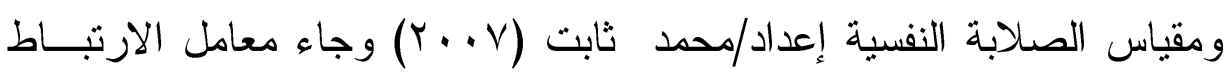

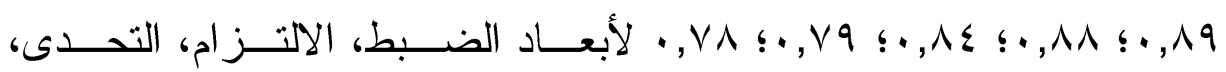

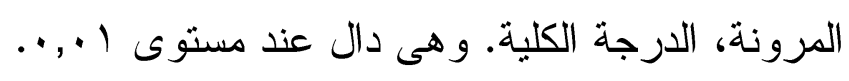
[ب] - ثبات الاختبار:

- طريقة النطبيق و إعادة النطبيق: حسبت الباحثة معامل الثبات بطريقة النطبيق و إعادة تطبيق المقياس على عينة الدراسة الاستطلاعية بفارق زمني (10) يوماً، وجاءت معاملات الارتباط بين

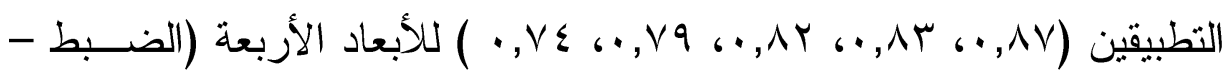

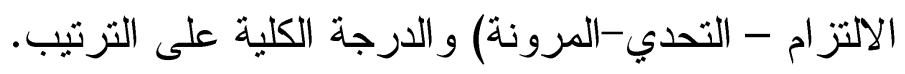
- التطبيق بمعادلة ألفا كرونباخ:

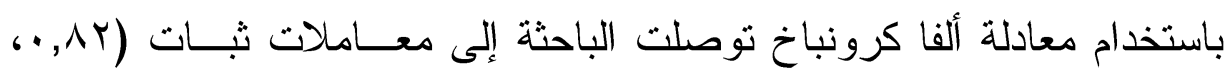

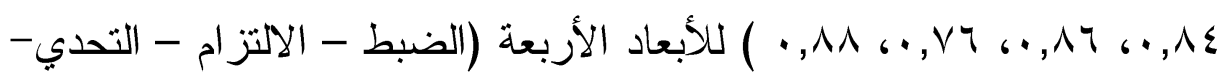
المرونة) و الدرجة الكلية على التزتيب 
- الاتساق الداخلي للمفردات مع الدرجة الكلية لكل بعد:

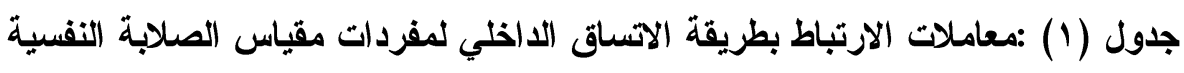
ميع الارجة الكلية للبعد الأى تنتمى إليه

\begin{tabular}{|c|c|c|c|c|c|c|c|}
\hline معامـــل الارتباط & بع المرونة & معامـــلـل & 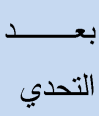 & الارثباط & 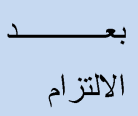 & معامـــل الارتباط & بعــــــــ \\
\hline$\cdot, V V$ & ro & $\cdot, 71$ & IV & $\cdot, V V$ & 9 & $\cdot,{ }^{\prime}$ & 1 \\
\hline$\cdot, \vee \diamond$ & דץ & $\cdot, 79$ & 11 & $\cdot, \vee \vee$ & 1. & $\cdot, \wedge \wedge$ & r \\
\hline., 09 & $r V$ & זT, • & 19 &., 09 & 11 & $\cdot, 71$ & r \\
\hline$\cdot, V V$ & rA & $\cdot, 7)$ & $r$. & $\cdot, 91$ & Ir &., 79 & $\varepsilon$ \\
\hline$\cdot, \wedge \varepsilon$ & rq & $\cdot, V_{1}$ & YI & $\cdot$ • TV & r & זT, & 0 \\
\hline • & r. & $\cdot, T V$ & YY & זד, • & $1 \varepsilon$ & $\cdot, V$ & 7 \\
\hline$\cdot, 9 r$ & r & $\cdot, \vee \vee q$ & r & $\cdot, V V$ & 10 & $\cdot, V \leqslant$ & V \\
\hline$\cdot, V 7$ & r & $\cdot, 94$ & $r \varepsilon$ & $\cdot, 0 \mathrm{~V}$ & 17 &., 70 & $\wedge$ \\
\hline
\end{tabular}

ـالاتساق الداخلي للمفردات مع الدرجة الكلية للمقياس:

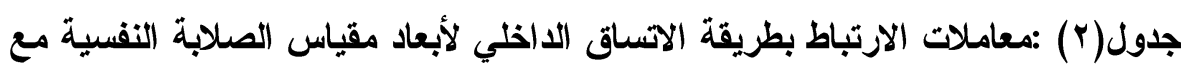
بعضها البعض ومع الارجة الكلية

\begin{tabular}{|c|c|c|c|c|c|c|c|}
\hline معامــــــلـ & r & معامــــــل & r & معامــــل & r & معامل الارتباط & r \\
\hline$\cdot, \wedge \vee$ & ro & $\cdot, \vee \circ$ & iv & $\cdot, \wedge \wedge$ & 9 & $\cdot, \vee \circ$ & 1 \\
\hline$\cdot, T V$ & YT &., $0 \mathrm{~V}$ & 11 & $\cdot, T V$ & 1. & $\cdot, \vee \vee$ & r \\
\hline$\cdot, T Y$ & YV & $\cdot, \wedge)$ & 19 & $\cdot, 09$ & 11 & $\cdot, \vee \circ$ & $r$ \\
\hline$\cdot, \vee V$ & $r \wedge$ & $\cdot, V Y$ & $r \cdot$ & אד, • & Ir & $\cdot, \wedge \wedge$ & $\varepsilon$ \\
\hline$\cdot, \vee Y$ & rq & $\cdot, \times 1$ & YI & $\cdot, 0 \mathrm{~V}$ & Ir & $\cdot, 71$ & 0 \\
\hline$\cdot, V \leq$ & r. & $\cdot, 9 r$ & rr &., 09 & $1 \varepsilon$ & $\cdot, 79$ & 7 \\
\hline., 70 & M & $\cdot, 79$ & سr & $\cdot, \vee \vee q$ & 10 & $\cdot, 7 r$ & v \\
\hline$\cdot, 71$ & rr & $\cdot,()_{1}$ & $r \leqslant$ & $\cdot, V \varepsilon$ & 17 & $\cdot, 09$ & $\wedge$ \\
\hline
\end{tabular}

- الاتساق الداخلي للأبعاد مع بعضها البعض ومع الدرجة الكلية: 
صلابة الثخصية وعلاقتها بأساليب مو اجهة الضغوط النفسية لاى المراهقين المكفوفين د. سهام عبد الغفور

جدول (r) :معاملات الارتباط بطريقة الاتساق الاخلي لأبعاد مقياس الصلابة النفسية مع بعضها البعض ومع الارجة الكلية

\begin{tabular}{|c|c|c|c|c|c|}
\hline الدرجة الكلية & المرونة & التحدي & الالتز ام & الضبط & أبعاد المقياس \\
\hline- & & - & - & - & الضبط \\
\hline- & & - & - & $\cdot, 10$ & الالتز ام \\
\hline- & & - & $\cdot, \vee \vee 9$ & $\cdot, 79$ & التحدي \\
\hline- & - & •, 94 & $\cdot, 0 \mathrm{~V}$ & r & المرونة \\
\hline- & $\cdot, 91$ & $\cdot$, OV & $\cdot, \vee \vee 9$ & $\cdot, 91$ & الدرجة الكلية \\
\hline
\end{tabular}

يتضح من الجدول السابق أن جميع معاملات الارتباط دالة وموجبة، وتنزاوح

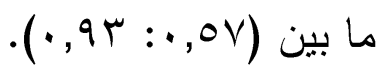

و على ذللك تكون الباحثة قد تأكدت من صدق وثبات المقياس بطــرق كثيــرة ومثتو عة مما يجعل استخدامه مناسباً وملائماً. r)

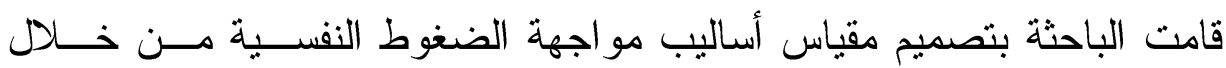
إطلاعها على بعض الأطر النظرية في مجال أساليب مواجهة الضغوط النفسية

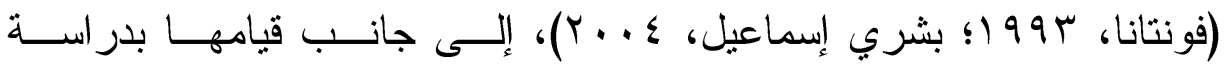
استطلاعية على مجموعة من المر اهقين المكفوفين للتعرف على بعض أساليب

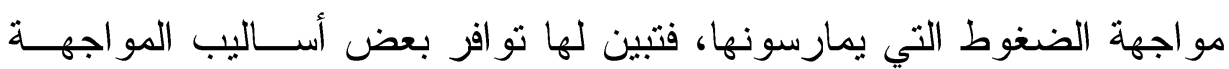

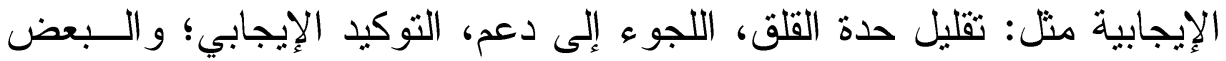

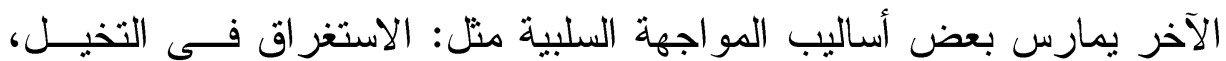

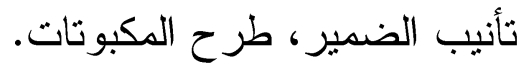

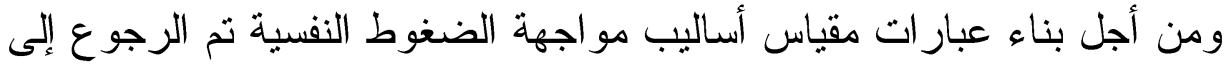

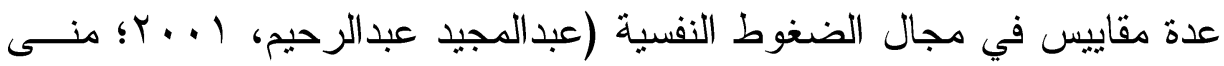
(') أنظر ملحق رقم (ب). 


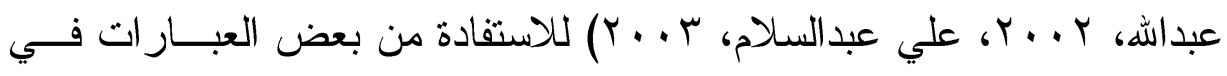
تصميم المقياس الحالي.

بعد بناء عبار ات أبعاد مقياس أساليب مواجهة الضغوط النفسية انتهى كل بعـــ

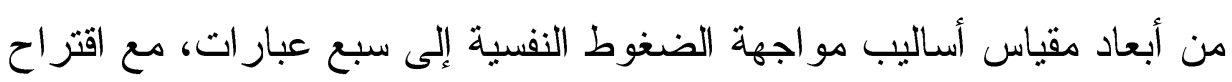

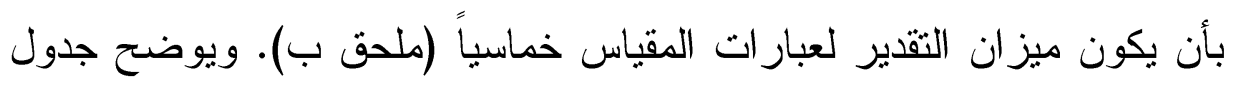
(ع) توزيع العبار ات على أبعاد المقياس، بعد توزيعها توزيعاً عشو ائياً.

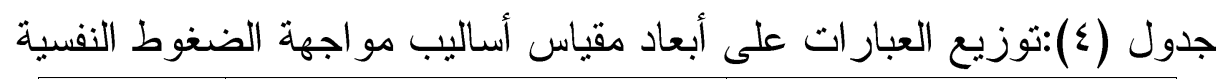

\begin{tabular}{|c|c|c|}
\hline المجموع الكلي & العبارات & أساليب مواجهة الضغوط النفسية \\
\hline v & l & تقليل حدة القلق \\
\hline v & rA, , & اللجو ء إلى دعم \\
\hline v & r6 9، 10، ו & التوكيد الإيجابي \\
\hline v & ع & الاستغر اق في التخيل \\
\hline v & 0, & تأنيب الضمير \\
\hline v & ד, Yו & طرح المكبونات \\
\hline$\varepsilon r$ & & المجموع الكلي \\
\hline
\end{tabular}

و إلى جانب هذا، قامت الباحثة بحساب الخصائص السيكومترية لمقياس أساليب

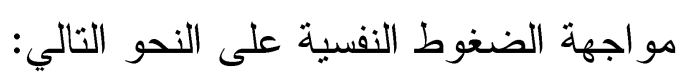
أ) الصدق - صدق المحكمين: تم عرض المقياس في صورته الأولية علـى (• (1) مسـن

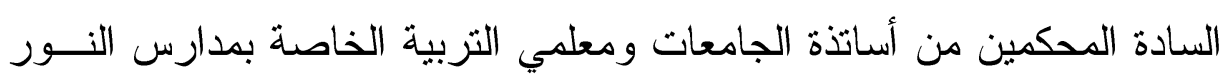
للمكفوفين، و أقرو ا جميعا بأن العبار ات تقيس ما وضعت من أجل قياسه

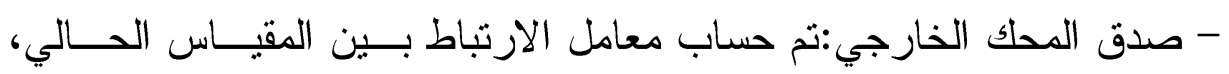

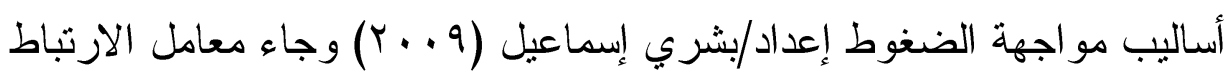

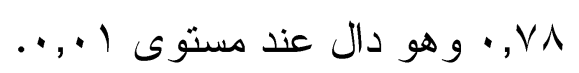


صلابة الثخصية وعلاقتها بأساليب مواجهة الضغوط النفسية لاى المراهقين المكفوفين د. سهام عبد الغفور

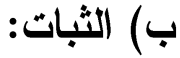

تم حساب معامل الثبات لمقياس أساليب مواجهة الضغوط النفسية مع الدرجــة

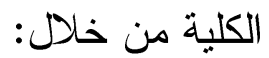

- معادلة ألفا كرونباخ، فبلغت معاملات الثبات على النحو التـالي: (اسT7, •)

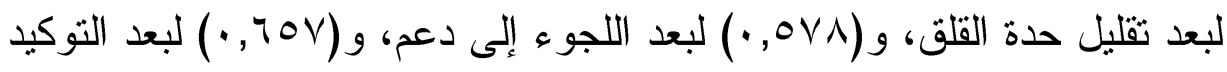

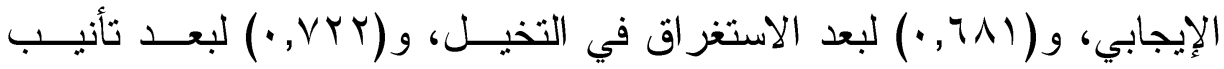

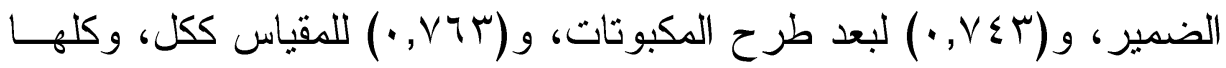
معاملات مقبولة إحصائياً.

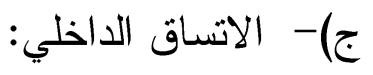

- الاتساق الداخلي للمفردات مع الدرجة الكلية لكل بعد:

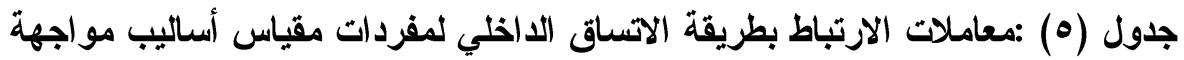
الضغوط ميع الارجة الكلية للبعد التى تنتمى إليه

\begin{tabular}{|c|c|c|c|c|c|c|c|c|c|c|c|}
\hline معامل & طبرح & معامل الارتباط & تأنيب & معامل الارتباط & الاستغراق في & الارتباط & التوكيد & معامل الارتباط & اللجدي & معامل الارتباط & تقليل \\
\hline$\cdot, \vee \vee$ & rq & זד, . & rq & $\cdot, V_{4}$ & YY & $\cdot, \vee \vee$ & 10 & $\cdot, 94$ & $\wedge$ & $\cdot, v_{1}$ & 1 \\
\hline$\cdot, V \varepsilon$ & rv & $\cdot, \diamond V$ & r. & $\cdot, \nabla \varepsilon$ & $r r$ & $\cdot, \vee \leqslant \varepsilon$ & 17 &., 79 & 9 & $\cdot, \vee \vee q$ & $r$ \\
\hline$\cdot, \vee \vee q$ & rᄉ & $\cdot, \vee \vee q$ & I & •ד, • & Y $\varepsilon$ & גד, • & iv & $\cdot, V_{1}$ & 1. & $\cdot, \vee \vee q$ & $r$ \\
\hline$\cdot, \mathrm{V} \varepsilon$ & rq & $\cdot, \vee \vee \varepsilon$ & rr & וד, & Yo & זדו, & 11 & $\cdot, \Lambda_{1}$ & 11 & $\cdot, V \varepsilon$ & $\varepsilon$ \\
\hline$\cdot, \leqslant 1$ & $\varepsilon$ &., 09 & rr & . & YY &.,$O V$ & 19 & $\cdot, V Y$ & Ir & $\cdot, \vee \vee q$ & 0 \\
\hline$\cdot, \lambda r$ & \&1 & $\cdot, \diamond V$ & $r \varepsilon$ & צוד, • & YV &., 09 & $r$. & $\cdot, V_{1}$ & IT & $\cdot, V \varepsilon$ & 7 \\
\hline$\cdot, \wedge$ & $\varepsilon r$ & ו & o & $\cdot, \wedge_{1}$ & r^ & $\cdot, \vee \wedge$ & MI & $\cdot, \mathrm{V}^{\circ}$ & $1 \varepsilon$ & ., \&1 & v \\
\hline
\end{tabular}

- الاتساق الداخلي للمفردات مع الدرجة الكلية للمقياس: 
جدول (7) :معاملات الارتباط بطريقة الاتساق الاخلي لأبعاد مقياس أساليب مواجهة

الضغوط مع بعضها البعض وميع الارجة الكلية

\begin{tabular}{|c|c|c|c|c|c|c|c|c|c|c|c|}
\hline الارتباط & ? & الارتباط & ? & الارتباط & ? & الارتباط & ? & الارتباط & ? & الارتباط & ? \\
\hline$\cdot, \vee \vee$ & דצr &., 79 & rq & $\cdot, \varepsilon)$ & rY & $\cdot, \vee \vee$ & 10 &,$V \varepsilon$ & $\wedge$ &.,$q Y$ & 1 \\
\hline . & $r v$ & $\cdot, v)$ & $r$. &., $0 \mathrm{~V}$ & r & 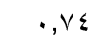 & 17 &., 09 & 9 &., 79 & $r$ \\
\hline$\cdot, \vee \vee 9$ & $\mu_{\Lambda}$ & $\cdot, \wedge)$ & $\mu_{1}$ & $\cdot, \Delta r$ & $Y \varepsilon$ & גד, & IV &., $0 \mathrm{~V}$ & 1. & $\cdot, v)$ & $r$ \\
\hline$\cdot, \vee 99$ & rq & $, V, V Y$ & rT & $\cdot, v)$ & ro &,$V \leqslant$ & 11 & $\cdot, \lambda r$ & 11 & $\cdot, \lambda)$ & $\varepsilon$ \\
\hline$\cdot, V \varepsilon$ & $\varepsilon$ & $\cdot, Y)$ & r & $\cdot, \leqslant 1$ & Tr & $\cdot, V V$ & 19 & $\cdot, \vee \wedge$ & Ir & $\cdot, V Y$ & 。 \\
\hline$\cdot, \vee \vee 9$ & \&1 &., 79 & $r \varepsilon$ &., $0 \mathrm{~V}$ & $r V$ & $\cdot, \lambda)$ & $r$. & $\cdot, 0 \mathrm{~V}$ & $1 \pi$ & $\cdot, \times)$ & 4 \\
\hline$\cdot, V \varepsilon$ & $\leqslant Y$ & $\cdot, v^{\prime}$ & ro & •, & rA & $\cdot, \vee \vee$ & $r$ & $\cdot, V \leqslant$ & $1 \leq$ & , vo & V \\
\hline
\end{tabular}

- الاتساق الداخلي للأبعاد مع الدرجة الكلية:

تم حساب الاتساق الداخلي لأبعاد مقياس أساليب مواجهة الضغوطه، مع الدرجة

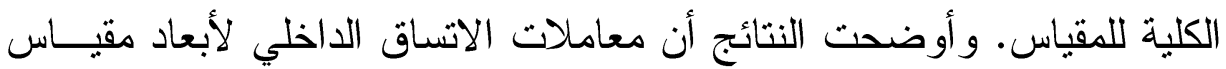

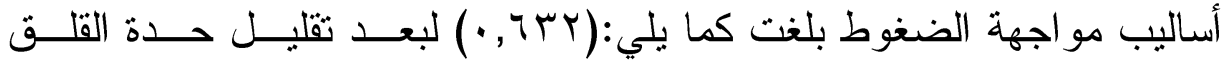

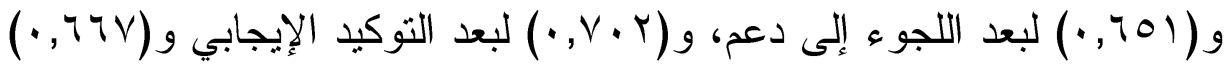

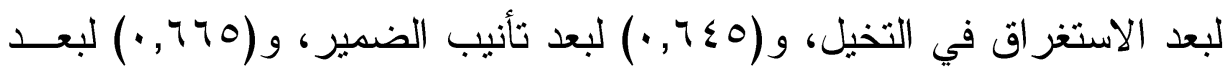

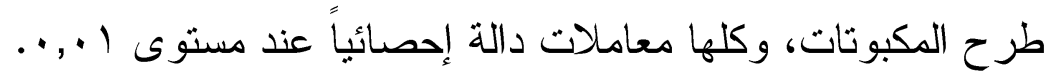
وبذلك تكون الباحثة قد تأكدت بطرق كثيرة ومتتو عة من صدق المقياس وثباته.

\section{خطوات البحث}

الاطلاع علي أدبيات تربوية ونفسية تناولت متغير ات البحث الحالي من خلال البحوث و الدراسات السابقة، وأيضاً الإطار النظري من البـات البحث الحالي بغرض

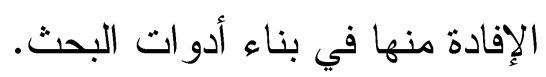

تقنين أدوات البحث الحالي السابق ذكرها و القيام بالتطبيق الاستطلاعي. تطبيق أدوات البحث علي المراهقين المكفوفين بمدارس النــور بكفر الثـــيخ طنطا. مناقشة النتائج وتفسير ها و التحقق من قبول أو رفض فروض البحث. 
تقديم بعض التوصيات و المقترحات التربوية في ضوء ما أسفرت عنه نتـائج البحث.

ينص على أن" توجد علاقة بين الدرجات على مقبــاس صــلابة الشخصــية

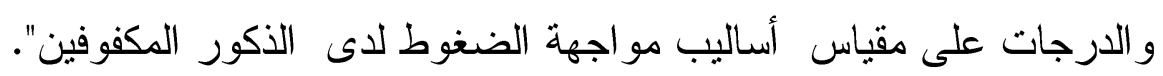

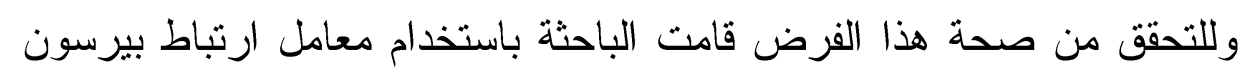

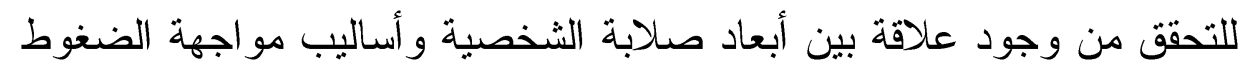

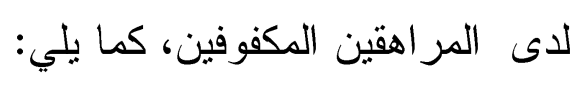
جدول (V): معاملات الارتباط بين أبعاد صلابة الثخصية وأساليب مواجهة الضغوط لاىى لإل

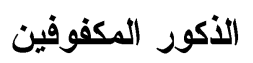

\begin{tabular}{|c|c|c|c|c|c|}
\hline \multicolumn{4}{|c|}{ صلابة الشخصية } & \multirow{2}{*}{ العينة } & \multirow{2}{*}{ المتغير ات } \\
\hline المرونة & التصدي & الاكتزام & الضبط & & \\
\hline *, or & $* ., 01$ & $*, r \varepsilon$ & $*,, \varepsilon r$ & تقليل حدة القلق & \multirow{6}{*}{ الضغوط } \\
\hline *, or & $*, 00$ & $*$, . $\{\leqslant$ & $*,, \leqslant 0$ & اللجو \& إلى دعم & \\
\hline$*, V Y$ & $*, 4$. & $*,, \varepsilon Y$ & *., \& & التوكيد الإيجابي & \\
\hline$* \cdot, \Delta r-$ & $*$, , OrI- & $*,,\{\leqslant-$ & $*, r-$ & الاستغراق في التخيل & \\
\hline$* \cdot, 74-$ & $*,, 70-$ & $*,, 0 \leq-$ & $*$., \一- & تأنيب الضمير & \\
\hline$*,, \Delta r-$ & $*$, , $17-$ & $*,, \vee 7-$ & $*, .07-$ & طرح المكبوتات & \\
\hline
\end{tabular}

$$
\text { * دالة عند مستوى ال ط, •. }
$$

يتضح من الجدول السابق وجود ارتباط موجب دال بين صلابة الثخصــية الثية

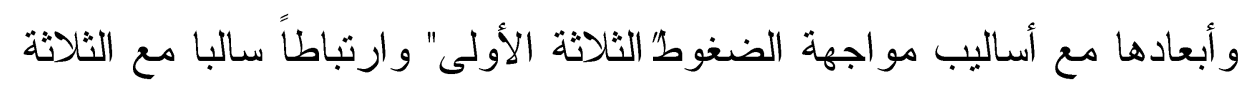
الباقيين وجميعها دالة عند مستوى ل .., ..

$$
\text { [ب] - نتائج الفرض الثاني: }
$$

ينص على أن" توجد علاقة بين الدرجات على مقياس صــلابة الثخصـــية

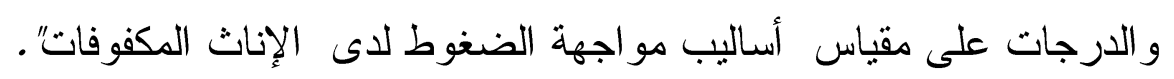


وللتحقق من صحة هذا الفرض قامت الباحثة باستخدام أسلوب معامـلـل

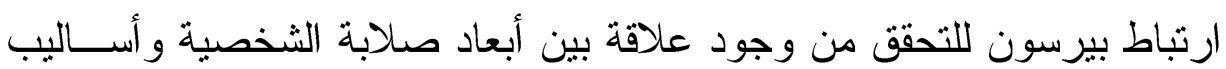
مو اجهة الضغوط للى الإناث المكفوفات، كما يلي:

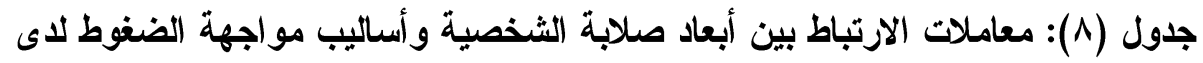
الإناث المكفوفات

\begin{tabular}{|c|c|c|c|c|c|}
\hline \multicolumn{4}{|c|}{ صلابة الشخصية } & \multirow{2}{*}{ العينة } & \multirow{2}{*}{ المتغير ات } \\
\hline المرونة & التحدي & الالتز ام & الضبط & & \\
\hline$* * ., 799$ & $* *, r \wedge \wedge$ & $* *, \Sigma T r$ & $* * ., 01 \leqslant$ & تقليل حدة القلق & \multirow{6}{*}{ أساليب } \\
\hline$* *,, \vee\urcorner$ & **, & $* * ., 011$ & **., & اللجـــــ إلــى & \\
\hline$* *, \vee \wedge \wedge$ & $* *, r V V$ & $* *, 0.1$ & $* *, r q \wedge$ & الإلتوكيج & \\
\hline$* *, 07 \mathrm{~V}-$ & **,orr- & $*_{*}, \varepsilon Y V-$ & **., YTV & الاستخراق في & \\
\hline$* *, \wedge \cdot 1-$ & $* *, 00 \mathrm{~V}-$ & **,ory- & $* *$, TVO- & تأنيب الضمير & \\
\hline$* * ., 011-$ & **, ฯ Ү人ฯー & $* *, 0 \leqslant 1-$ & $* * ., 070-$ & 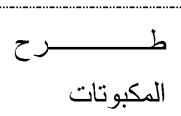 & \\
\hline
\end{tabular}

يتضح من الجدول السابق وجود ارتباط موجــب دال بــين صــلابة الثخصبة وأبعادها مع أساليب مو اجهة الضغوط" الثناثة الأولى" وارتباطاً سالبا

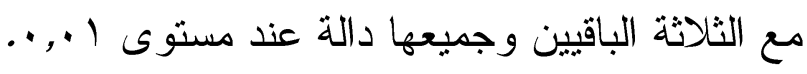
- تفسير نتائج الفرضين الأول و الثاني: تلاك نتيجة توقعتها الباحثة لدى المكفوفين الذكور و الإناث من عينة البحــث

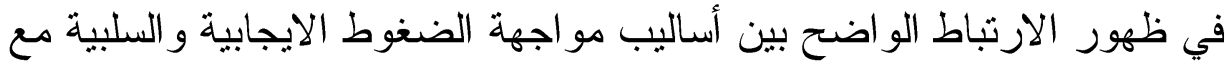

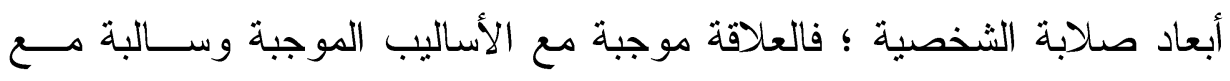


الأساليب السالبة، فالضغوط تتمنل في"حالة يعانيها الفرد حين يو اجه بطلب ملح

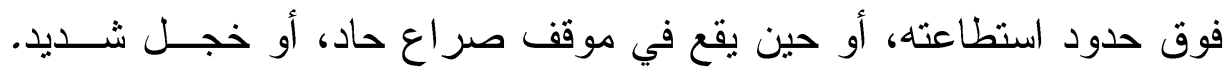

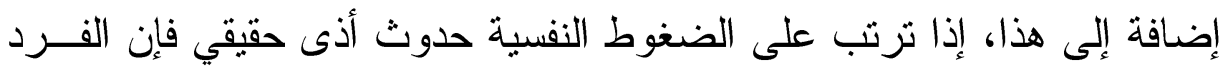

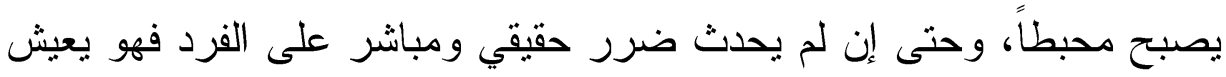

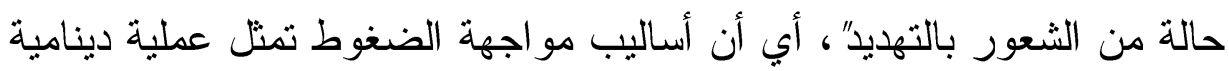

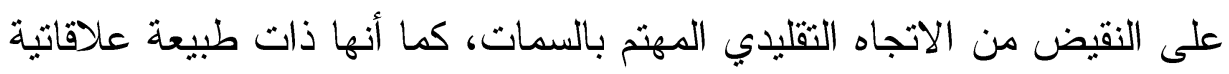
تعكس العلاقة بين الفرد و البيئة، وأيضـاً تكاملية تــربط المكونــات و العو امـلـل المختلفة المتعددة لعملية الضغوط. لذلك فالمواجهة مجهودات معرفية سـلوكية ولهية

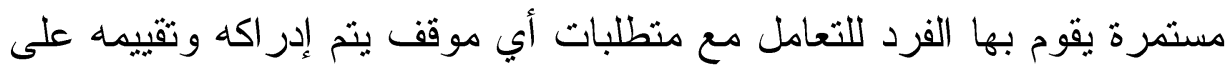

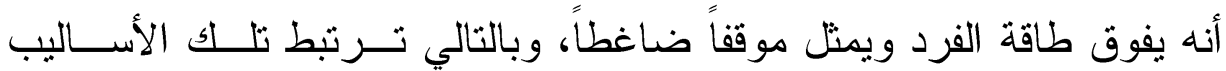

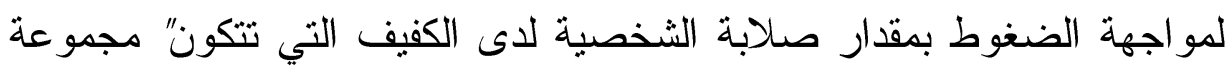

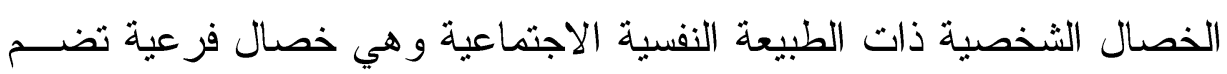

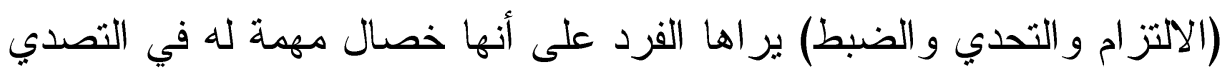
للمو اقف الصعبة أو المثيرة للمشقة النفسية وفي التعايش معها بنجاح.

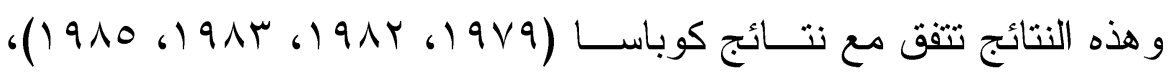

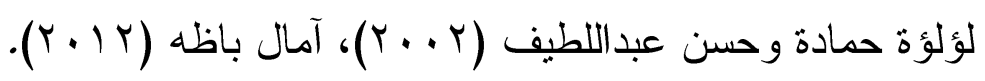

فصلابة الثخصية مصدر من المصادر الشخصية الذاتية لمقاومــة الآثـار السلبية لضغوط الحياة والتخفيف من آثار ها على الصحة النفســية و الجســـية

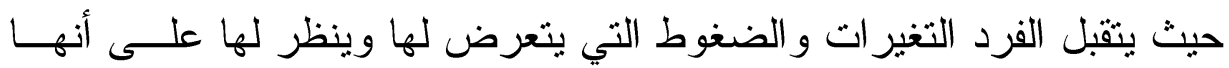
نوع من التحدي وليس تهديداً فيركز جهوده على الأعمال التي تؤدي غرضئس

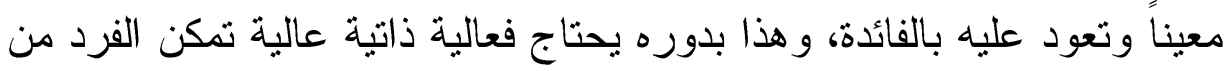
التكيف مع الوضع المحيط به. 


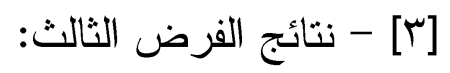

ينص على أن" نوجد فروق دالة إحصائياً بين الذكور والإناث من المر اهقين

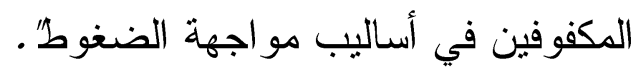

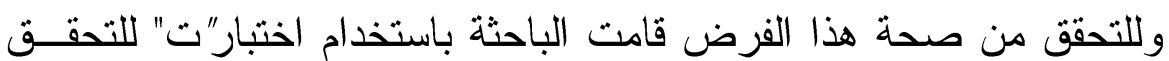

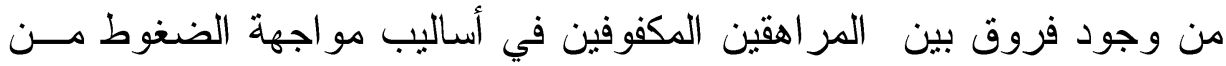

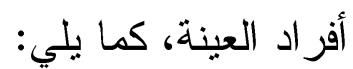

\begin{tabular}{|c|c|c|c|c|c|c|c|c|}
\hline \multirow{2}{*}{ الإلإحصائية } & \multirow{2}{*}{ قيمة ت" } & \multicolumn{3}{|c|}{ الإناث } & \multicolumn{3}{|c|}{ الذكور } & \multirow{2}{*}{ متغير ات البحث } \\
\hline & & $\varepsilon$ & s & $\dot{ن}$ & $\varepsilon$ & s & ن & \\
\hline غير دالة & 1,9 & 1,10 & Y),$\leqslant q$ & ro & 1,70 & rr,VA & ro & تقليل حدة القلق \\
\hline غير دالة & 1,07 & 1,70 & 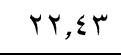 & ro & $Y, Y I$ & $19, \leqslant 9$ & ro & اللجوء إلى دعم \\
\hline غير دالة & 1,10 & 1,09 & $r_{\cdot}, \leqslant T$ & ro & $r, \wedge \vee$ & Y1,TV & ro & التوكيد الإيجابي \\
\hline غير دالة & $1,9 V$ & $1, \leqslant 7$ & rו, & ro & $r, 70$ & $r V, V T$ & ro & 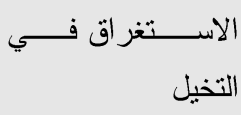 \\
\hline غير دالة & 1,09 & $1,7 \mathrm{~V}$ & $r 7, \varepsilon V$ & ro & ו & $r \leqslant, V T$ & ro & تأنيب الضمير \\
\hline غير دالة & $1, V Y$ & $r, \cdot r$ & $r V, O \leq$ & ro & $1, \mu \wedge$ & Y & ro & طرح المكبوتات \\
\hline غير دالة & $1, \cdot \leqslant 0$ & $\varepsilon, \vee Y$ & $1 \leq 9,70$ & ro & r, 79 & $1 \leq r, v q$ & ro & الدرجة الكلية \\
\hline
\end{tabular}

جدول (9): دلالة الفروق بين الأكور والإخاث من المراهقين المكفوفين في أساليب مواجهة الضغوط

يتضح من الجدول السابق عدم وجود فروق ذات دلالة إحصائية بين الذكور

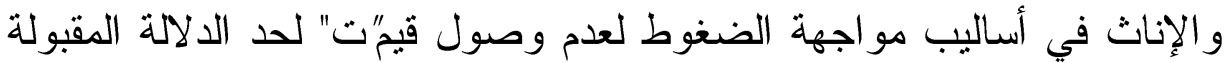
إحصائياً.

ولكنها تتفق مع در اسة كومسار ور امسامورثي (Kumar, Ramamouti 1990) ودر اسة رتيز (Raetx, 2002) حيث أوضحث هذه الدر اسات أن هناك فروقاً بـين

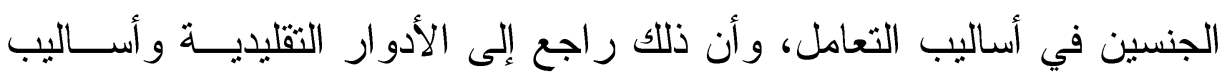

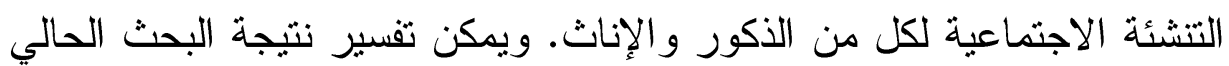

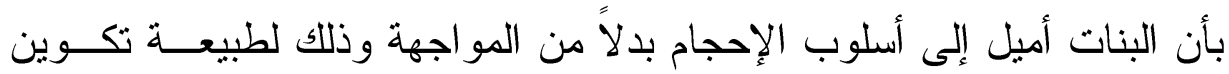

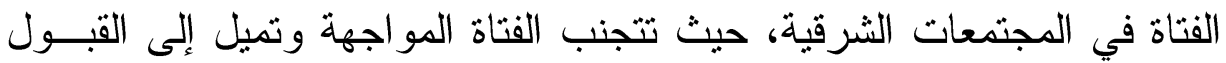


و الاستسلام و الانسحاب المعرفي الذي يتمثل في الاستغراق في أحلام اليقظـــة و التقكير في موضو عات بعيدة عن المشكلة.

ولما كان الكفيف لا يمكنه الانتفاع بحاسة البصر في أغر اض الحياة العادية

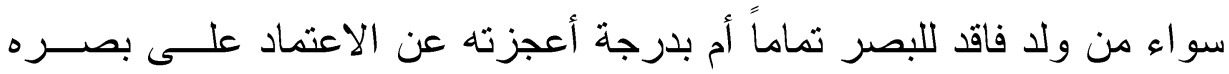

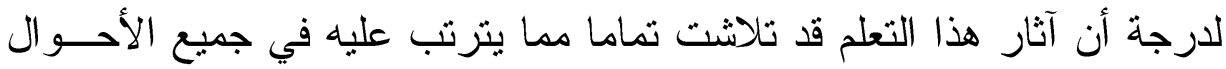

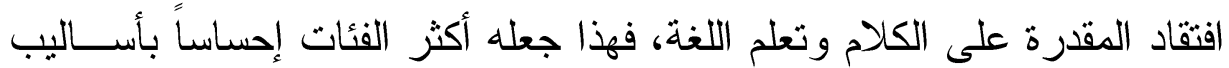

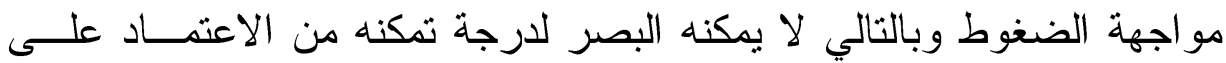

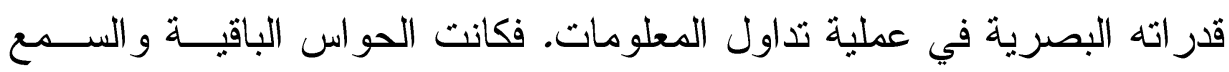

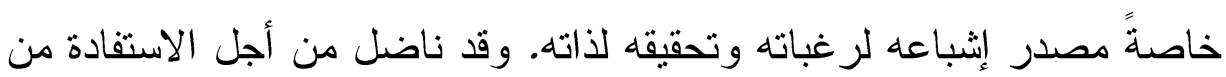

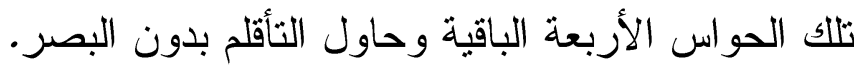

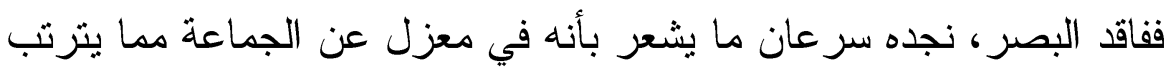

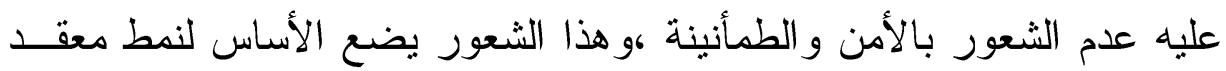

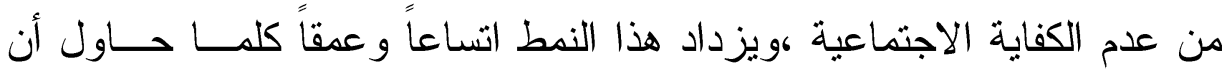
يؤكد الأمن لنفسه ،وأن يحقق ذاته في إطار الجماعة ،وفى كثير من الأحبـان النهان يو اجه عقبات بالغة لتعلم الثقة في البيئة المحيطة به من أجل الثعور بالئ بالثقة في

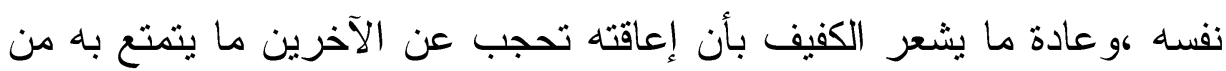

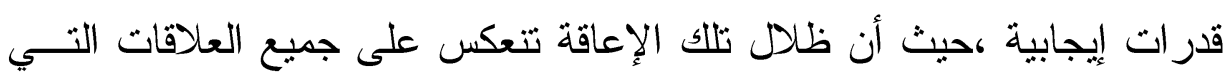

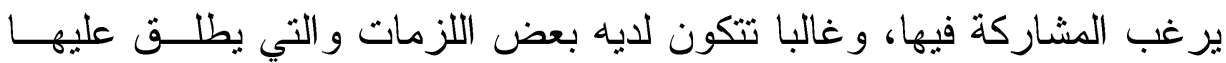

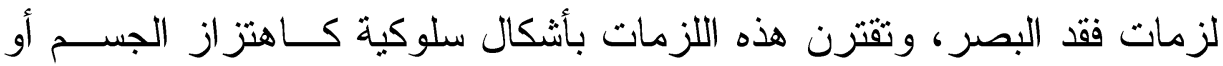

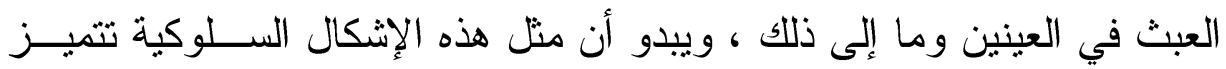

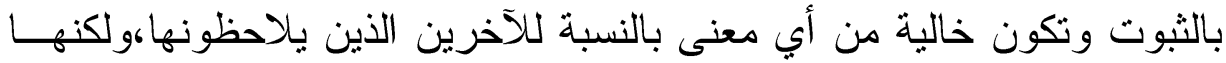

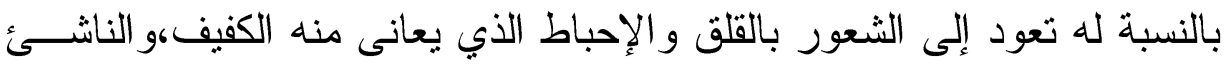

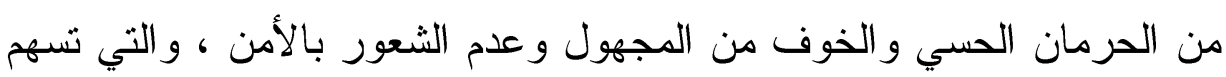


في زيادة التوتر النفسى ولكن تلك الفروق بين الذكور والإناث متلاشية ولكـن هنالك تذني في أساليب مو اجهة الضغوط النفسية لدى المكفوفين بصفة لنفة عامة.

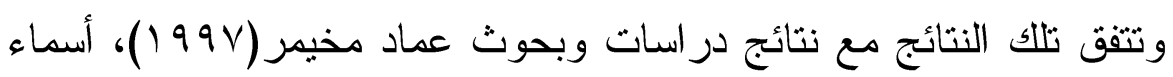

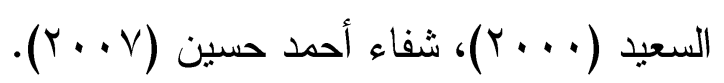

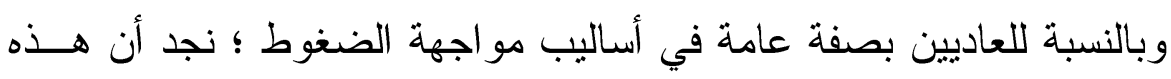

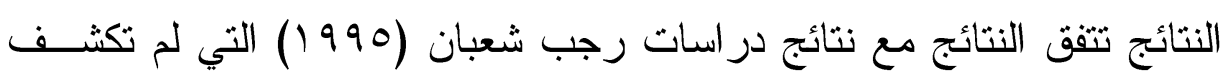
عن وجود فروق جوهرية في أساليب التكيف الإقدامية والإحجامية بين الذكور

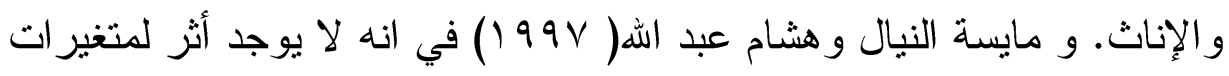

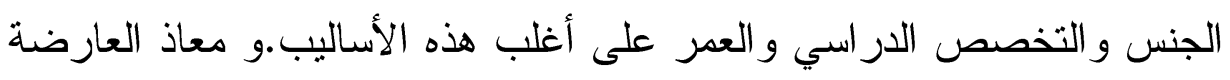

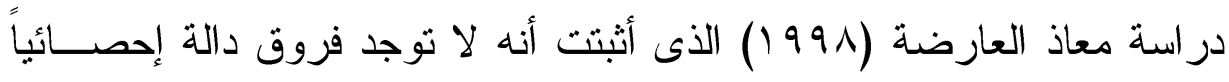

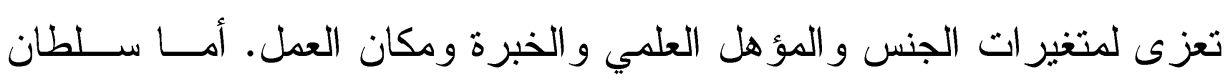

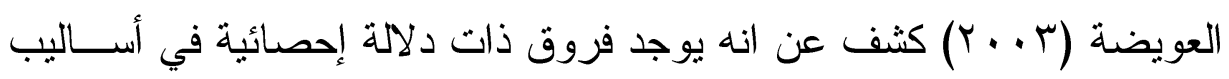
التعامل تعزى إلى متغير الجنس، تمويل الدراسة، الجنسية، الكلية، المســنتوى دئه

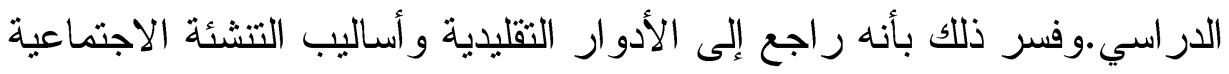

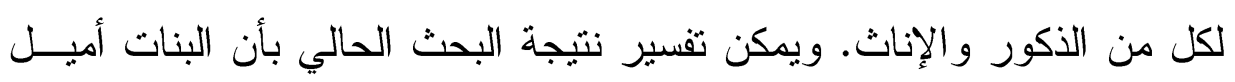

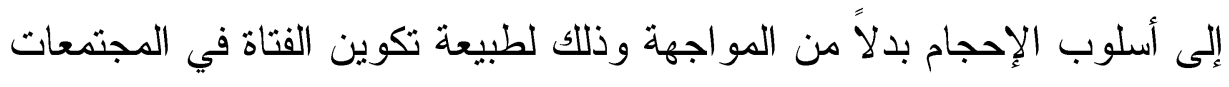

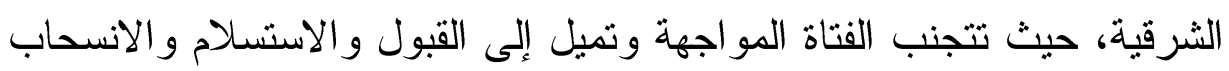

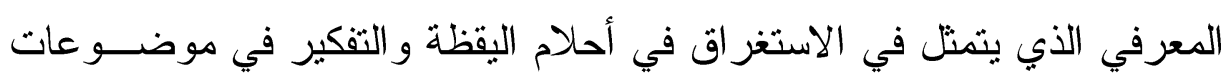
بعيدة عن المشكلة.

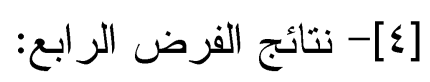
ينص على أن" توجد فروق ذات دلالة إحصائية بين متوســطات الــذكور و الإناث من المر اهقين المكفوفين في صلابة الثخصية". 


\section{صلابة الثخصية وعلافتها بأسائيب مواجهة الضغوط النفسية لاى المر اهقين المكفوفين د. سهام عبد الغفور}

وللتحقق من صحة هذا الفرض قامت الباحثة باستخدام اختبار"ت" للتحقـق

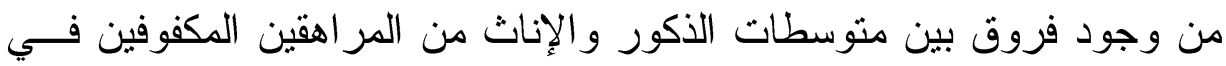

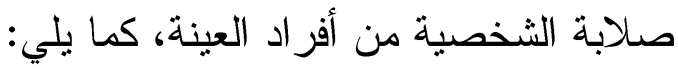
جدول ( • 1):دلالة الفروق بين الأكور والإناث من المراهقين المكفوفين في صلابة

\begin{tabular}{|c|c|c|c|c|c|c|c|c|}
\hline \multirow{2}{*}{ الإحصائية الدلة } & \multirow{2}{*}{ قيمةت" } & \multicolumn{3}{|c|}{ الإناث } & \multicolumn{3}{|c|}{ الذكور } & \multirow{2}{*}{ متغير ات } \\
\hline & & $\varepsilon$ & 5 & ن ن & $\varepsilon$ & 5 & ن ن & \\
\hline غير دالة & $1, Y \mu$ & 1,71 & $Y I, V V$ & ro & $1, \leqslant \varepsilon$ & $r, \mid r$ & ro & bu \\
\hline غير دالة & $1,1 r$ & $1, \leqslant 0$ & $r Y, I T$ & ro & $1, \leqslant 0$ & $19,0 \leqslant$ & ro & لتز ام \\
\hline غير دالة & $1, \pi q$ & $1,7 \mathrm{~V}$ & $r_{0,00}$ & ro & $1, r V$ & $r \leqslant, T \leqslant$ & ro & \\
\hline غير دالة & $1, \leqslant 9$ & $1, \leqslant 0$ & $r_{\top, \uparrow \wedge}$ & ro & $1,0 \leqslant$ & $r V, \cdot q$ & ro & |المرونة \\
\hline غير دالة & $1,0 \mathrm{~V}$ & $r, T V$ & $97,1 \pi$ & ro & $r, 9 \wedge$ & 94,1 & ro & لدرجة الكلية \\
\hline
\end{tabular}

يتضح من الجدول السابق عدم وجود فروق ذات دلالة إحصائية بين الذكور

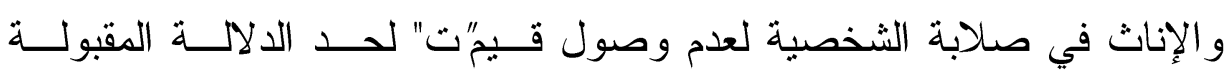
إحصائياً.

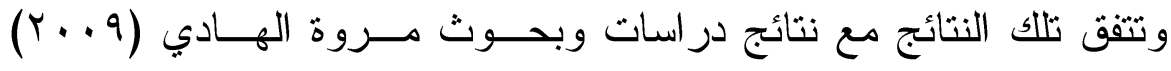

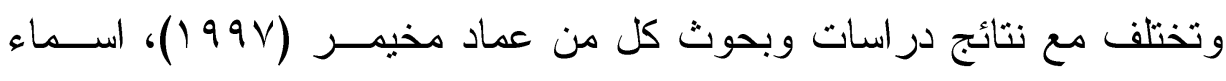

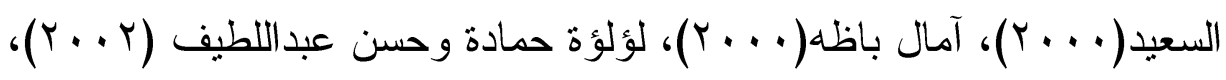

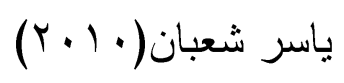

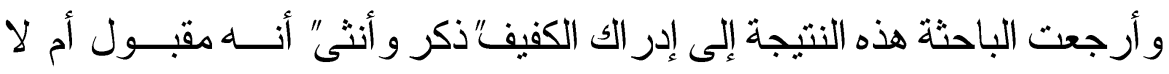

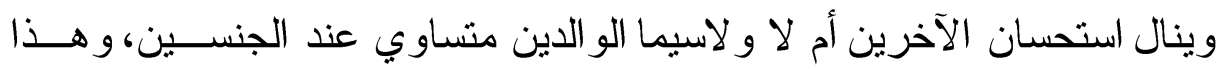

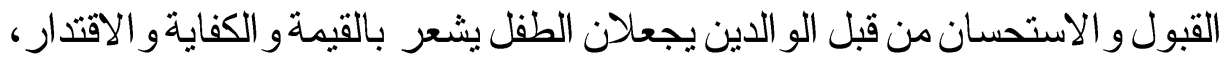


وأن هذا القبول و القيمة و الكفاية و الاقتدار يصاحبهم تشجيع من الو الدين و الأســرة

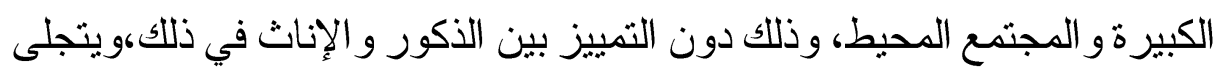
ذلك في اللعب مع الآخرين وحل المشكلات و التحصيل وكل مقومات الصلابة التي دوني

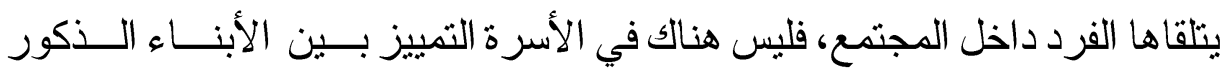

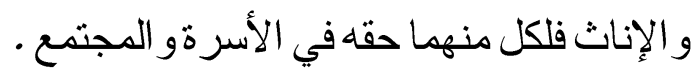
ولكون معظم الدراسات أجريت على عاديين أو فئات آخري، إلا أن البحث

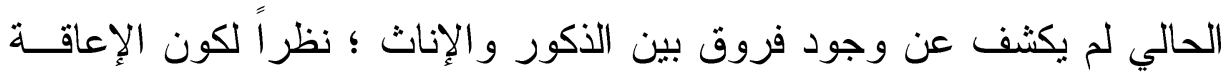

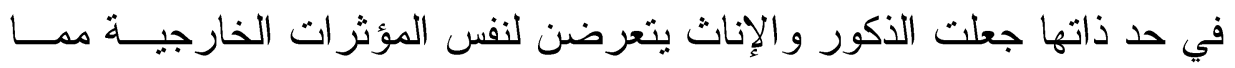
جعل تعاملهم مع المو اقف الخارجية متقاربة مما أدي بدوره إلى تلاشي الفروق في صلابتهم الشخصية. التوصيات والبدوث المقترحة: أ- التوصيات التربوية المنبثقة عن البحث. وتتمثل فى:-

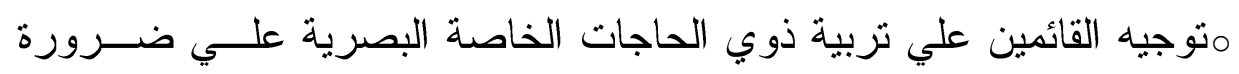
الاهتمام بصلابة الشخصية وأساليب مواجهة الضغوط لهؤل لاء الأفر اد.

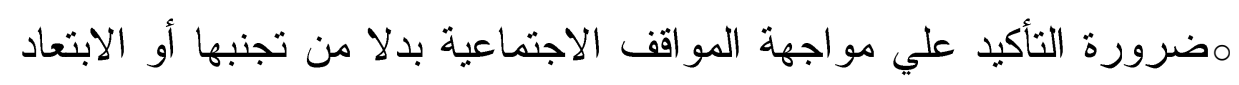
عنها. و أيضا الحث علي التعبير عن النفس بدلا من الانكماش و الصدت.

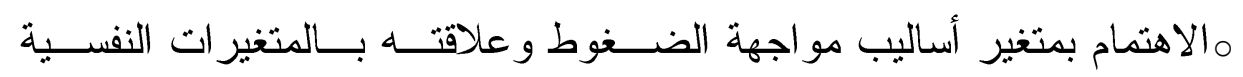
والاجتماعية الإيجابية.

مالاستثمار البشري في مجال المكفوفين من خلال تخفيف مشكلاتهم النفســية الإية

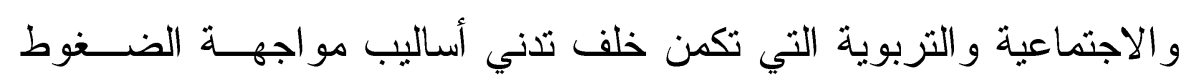
وصلابة الشخصية لديهر.

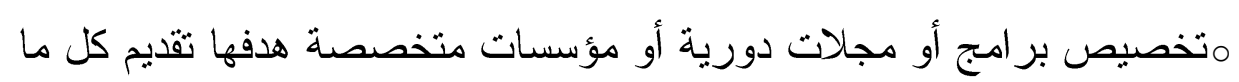

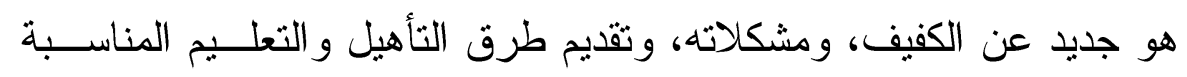


صلابة الثخصية وعلافتها بأساليب مواجهة الضغوط النفسية لاى المراهقين المكفوفين ـ. سهام عبد الغفور

لقدر ات و إمكانات هذا الفرد سو اء للمعلم و الأخصائي النفسي و الاجتماعي أم للو الدين.

ب- البحوث المقترحة: ثقتر ح الباحثة بعض البحوث منها:

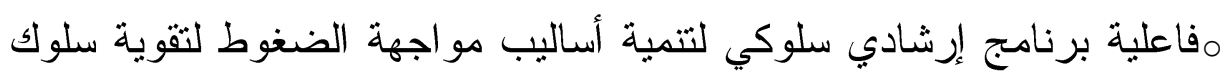
التحدي للمكفوفات.

مدر اسة أساليب مو اجهة الضغوط عبر شر ائح معينة من الإعاقــات المختلفـــة (المكفوفين، الصم و البكم، المتخلفين عقليا، المو هوبين.......الخ).

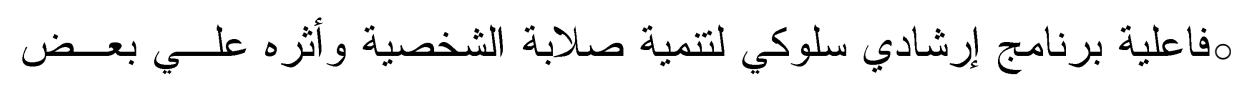
المتغير ات النفسية لدي المر اهقين المكفوفين.

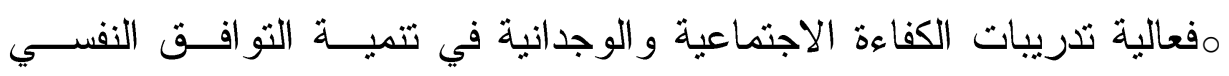
و الاجتماعي لدى المر اهقين المكفوفين على صلابة الشخصية.

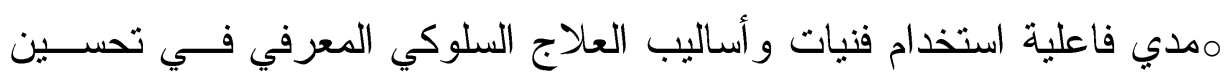
أساليب مو اجهة الضغوط لدي المر اهقين المكفوفين. 
المراجع

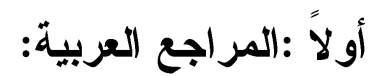
ا. أحمد حسين الثافعي (ب99 (19): القلق ووجهة الضبط لادي الأطفال المعاقين

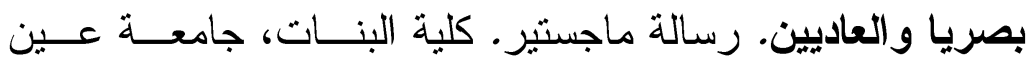
شمس.

r. أحمد عبدالرحمن عثمان (1 +. (Y). المساندة الاجتماعية وعلاقتها بالسـعادة

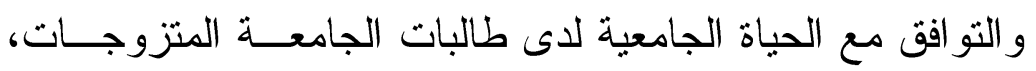
جامعة الزقازيق، كلية التربية، مجلة كلية التربية، العسدد (rV):

$$
.19 V-1 \leqslant r
$$

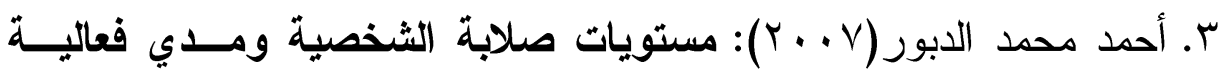

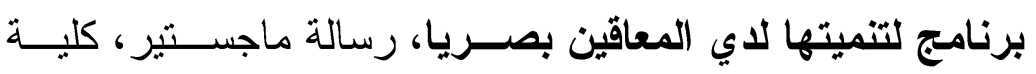
التزبية: جامعة المنوفية.

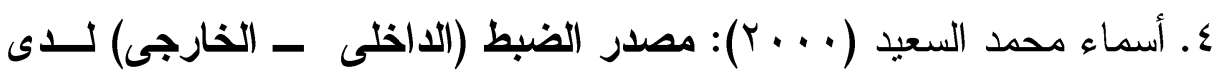

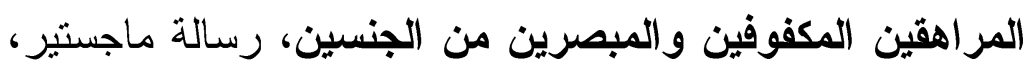
معهد الدراسات العليا للطفولة، جامعة عين شمس.

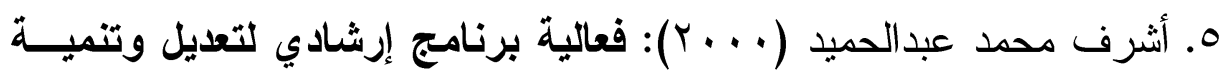

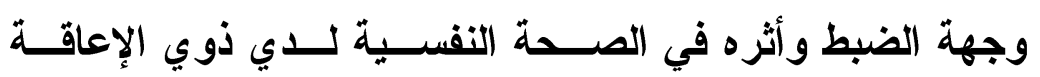
البصرية. رسالة دكتور اه، كلية التزبية. جامعة الزقازيق.

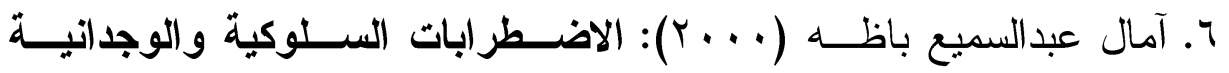

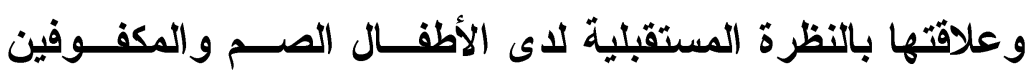
والعاديين V. آمال عبدالسميع باظه (11 (Y):الثعور بالاتتماء الوطني والقومي العربي

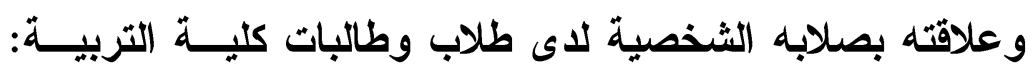


دراسة سيكومترية كلينيكية، مؤتمر الإرشــاد النفسـي الســنوي

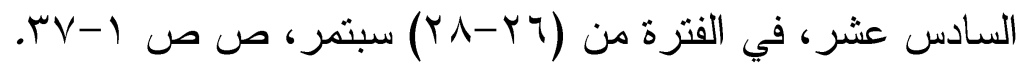

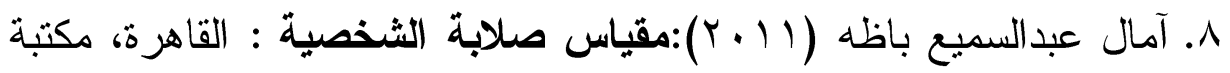
الانجلو المصرية.

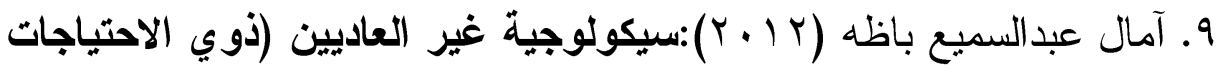
الخاصة)، مكتبة الانجلو المصرية: القاهرة.

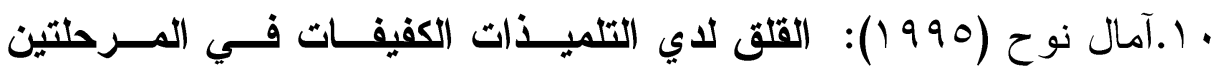
الإعدادية والثانوية. بحوث ودراسات في التربية الخاصة. (مجلا

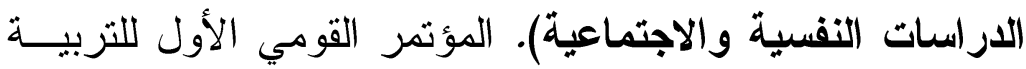
الخاصة في مصر ، القاهرة: وزارة التربية و التعليم. 11.إيهاب عبدالعزيز الببلاوي (999 ()): فعالية العلاج المعرفي السلوكي في خفض مستوي القلق لاي ذوي الإعاقة البصرية. رسالة دكتور اه، كلية التربية، جامعة الزقازيق.

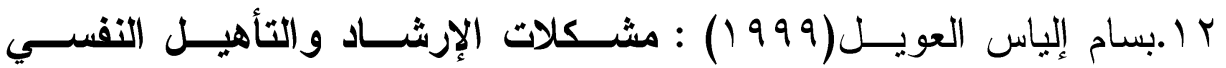
والاجتماعي للأطفال ذوي الحاجات الخاصة، بيروت، دار الخيال

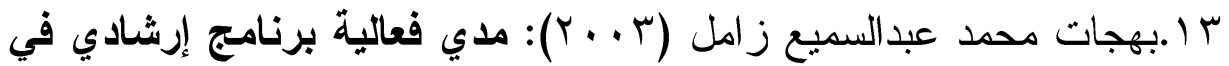
التخفيف من الثعور بالاغتراب لدي المـــراهقين مــن الأكفــاء.

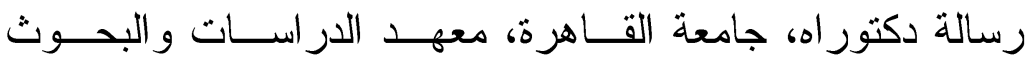
التزبوية، قسم الإرشاد النفسي.

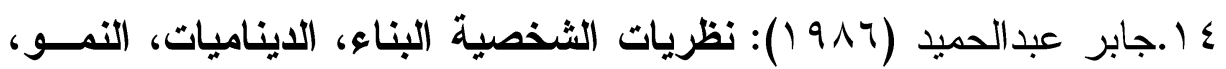
طرق البحث، التقويم، القاهرة، دار النهضة العربية.

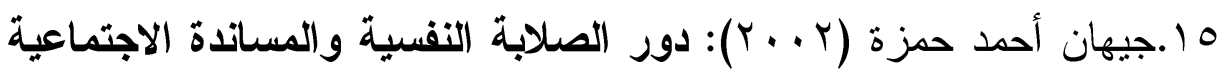
وتقدير الأات في إدرالك المشقة والتعايش معها لدى الراشدين من 
الجنسين في سياق العمل، رسالة ماجستير غير منشــورة، كلبـــة

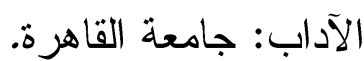

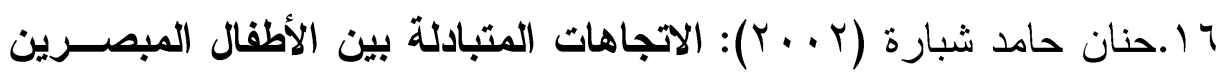

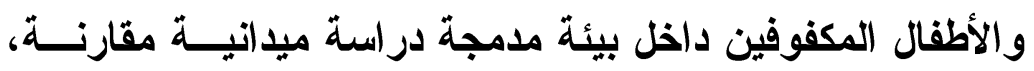

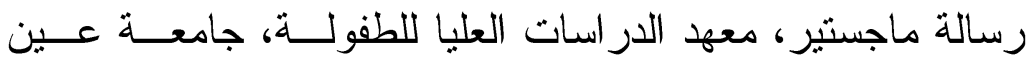
شمس.

IV خليل عبدالرحمن المعايطة، مصطفي القمش، محمد عبدالســلام البــواليز

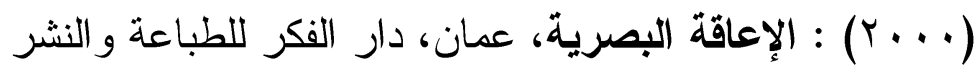

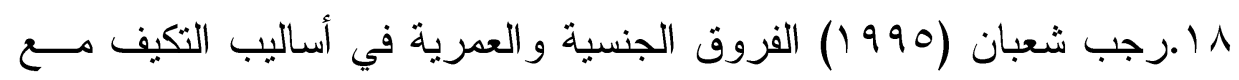
المو اقف الضاغطة، مجلة علم النفس، القاهرة، الهيئة المصــرية ولية

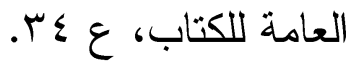
9 1.رمضان محمد القذافي (ع 99 ()): سيكولوجية الإعاقة، ليبيا، الدار العربية للكتاب.

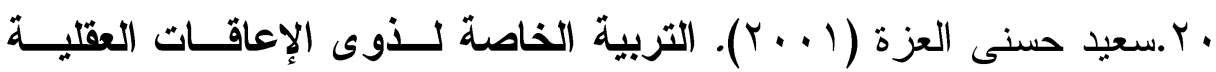

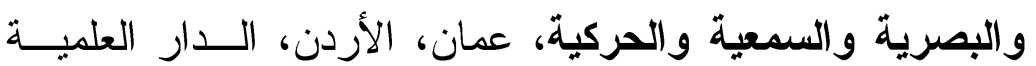
الدولية للنشر و التوزيع.

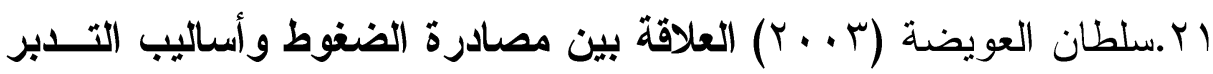

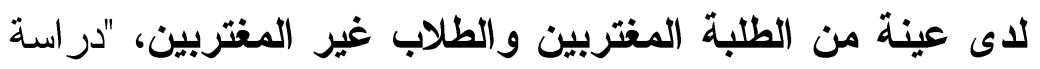

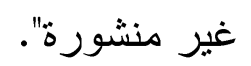

Y Y.سمير السيد شحاته (T . . Y): فاعلية برنامج لتنمية فعالية الذات للتخفيف

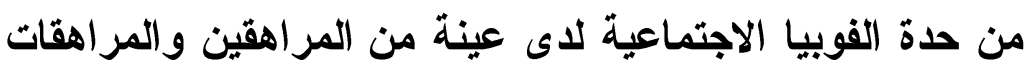
المكفوفين. رسالة ماجستير. كلية التربية، جامعة كفر الشيخ. 
بr.سمير عبدالخفار إبر اهيم (ب99 ()): التواقث الاجتماعي لاي بعض الأطفال

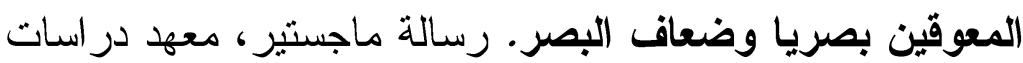
العليا للطفولة: جامعة عين شمس.

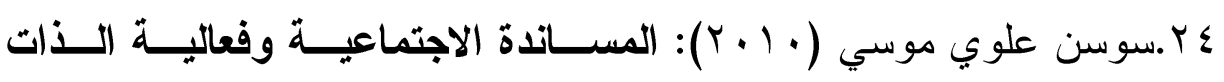
وأساليب التعامل مع الضغوط النفسية لاى عينة مـن معساوني أعضاء هيئة التدريس بالجامعة، رسالة ماجستير ، كلية التربيــة:

$$
\text { جامعة قناة السويس. }
$$

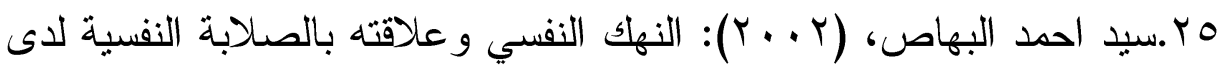

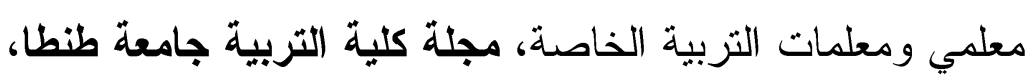

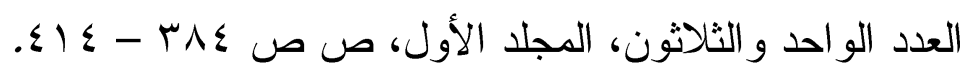

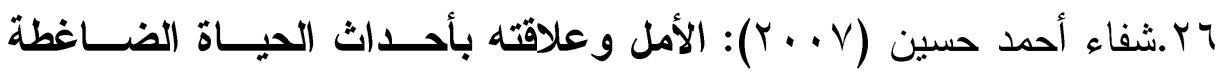
وبعض متغيرات الشخصية لاى عينة من خريجى الجامعة، رسالة ماجستير ، كلية التربية: جامعة المنيا.

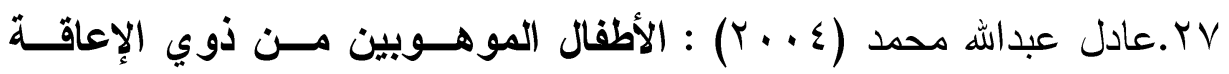

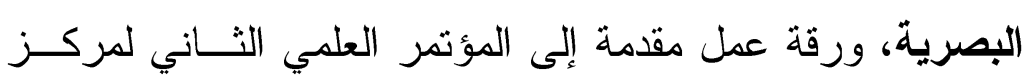

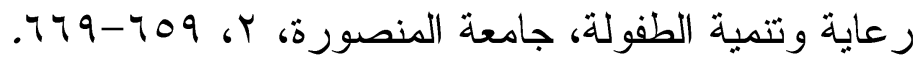

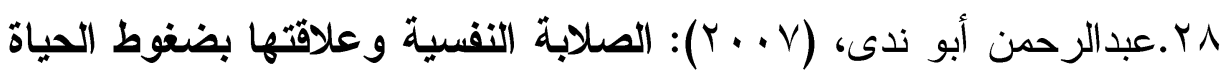

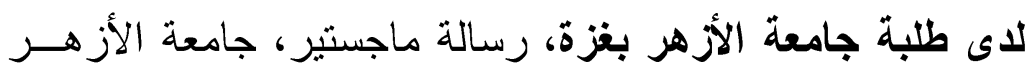
بغزة، كلية التزبية، قسم علم النفس.

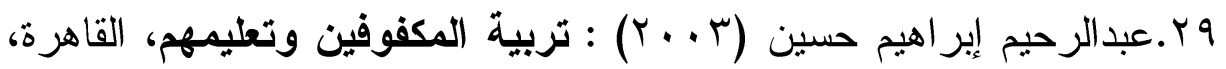
عالم الكتب. • r.عبدالسلام عبدالغفار ، يوسف الثيخ (910 (1): سيكولوجية الطفل والتربية. الخاصة. القاهرة: مكتبة النهضة العربية. 
اس.عبدالعزيز السيد الثخص (ـ99 (1): أثر أسلوب الرعاية علي مستوي القلق

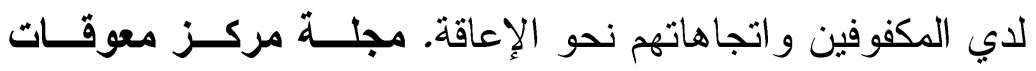

$$
\text { الطفولة. العدد الأول. }
$$

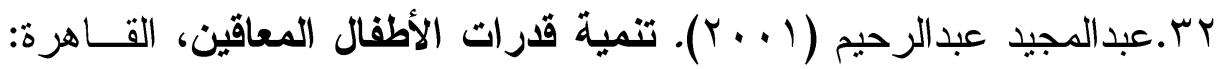

$$
\text { دار غريب للنشر و التوزيع. }
$$

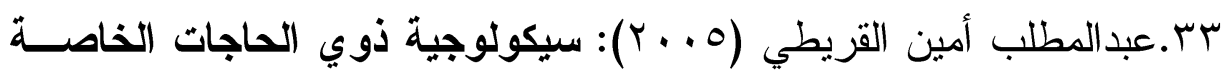

$$
\text { وتربيتهم. طب، القاهرة: دار الفكر العربي. }
$$

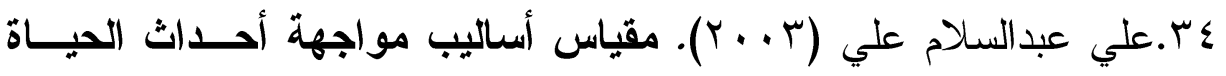

الضاغطة، القاهرة: مكتبة النهضة المصرية.

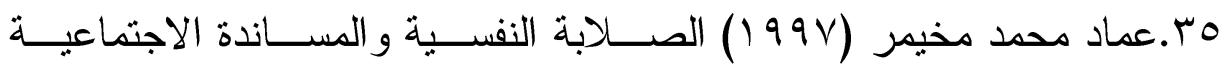

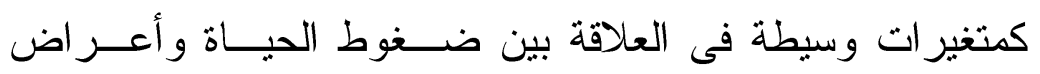

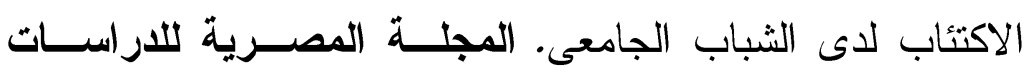

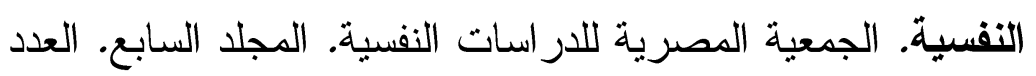

$$
.1 \mu \mathrm{N}-1 . r: I V
$$

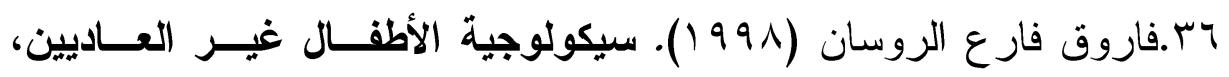

$$
\text { الرياض: مكتبة الصفحات الذهبية. }
$$

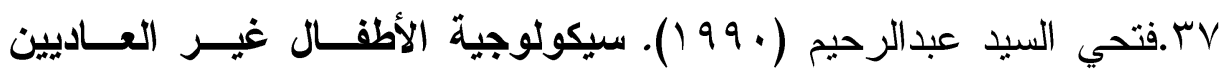

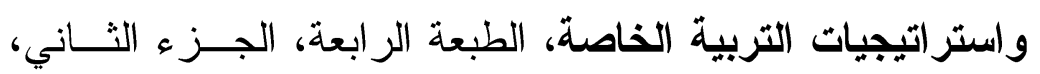

$$
\text { الكويت: دار القلم. }
$$

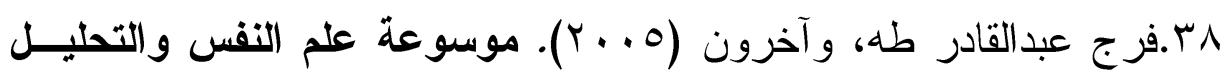

$$
\text { النفسي، الكويث: دار سعاد الصباح. }
$$

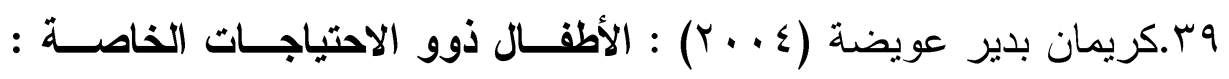

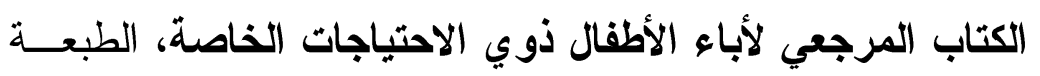

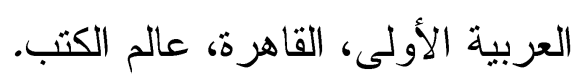
$\mu \cdot I$ 


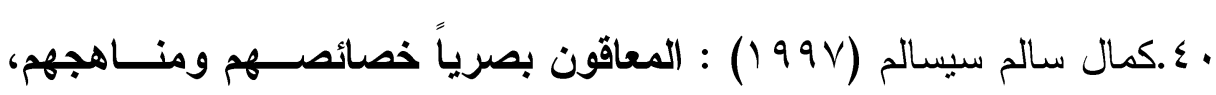
القاهزة، الدار اللبنانية.

اء.لطفي بركات أحمد (9^^ (1): الرعاية التربوية للمكفوفين. تهامــه: إدارة

$$
\text { النشر و التوزيع. }
$$

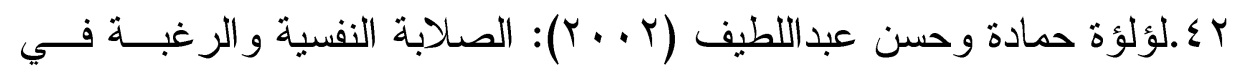

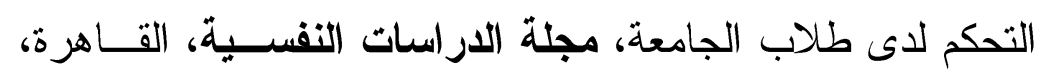

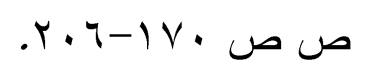

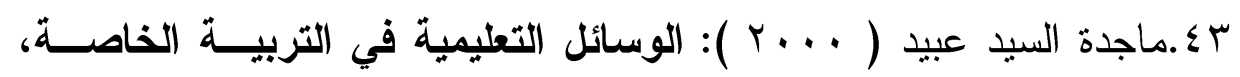

$$
\text { عمان، دار صفاء للنشر و التوزيع. }
$$

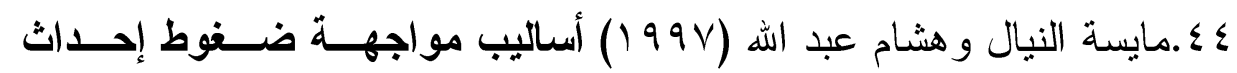

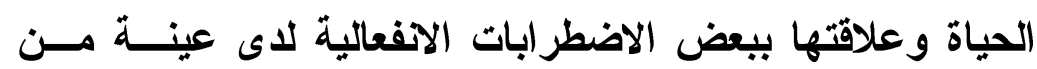

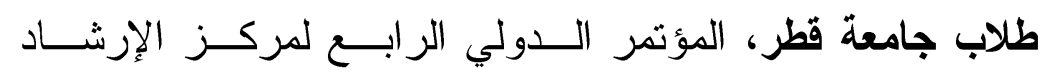
و الإرشاد النفسي، جامعة عين شمس، القاهرة.

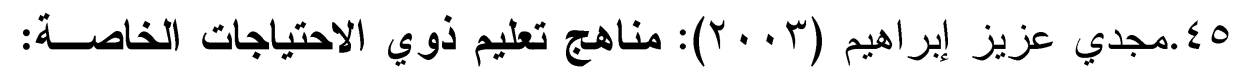

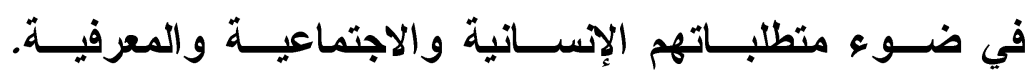
القاهرة:الأنجلو المصرية.

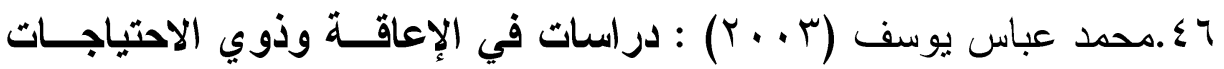
الخاصة، القاهرة، دار غريب للطباعة و النشر و التوزيع.

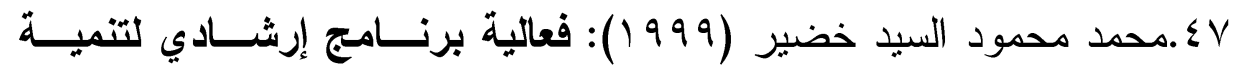
المسئولية الاجتماعية لاي المراهقين من ذوي الإعاقة البصرية. رسالة دكتور اه، كلية التربية: جامعة الزقازيق.

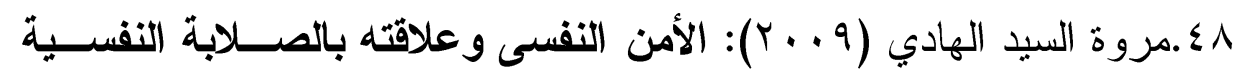

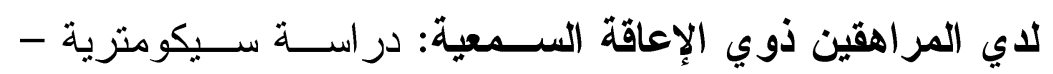
كلينيكية، رسالة ماجستير، كلية التربية: جامعة الزقازيق. 


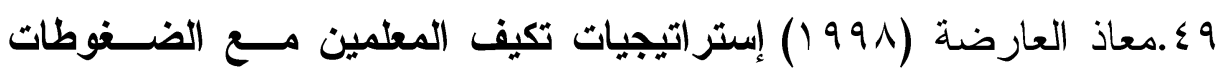
النفسية التي تواجههم في المــدارس الثانويـــة الحكوميــة فـــي محافظة نابلس، رسالة ماجستير غير منشورة، جامعــة النجـــاح، نابلس، فلسطين. • .منى حسين أبو طيرة (r . . r). أساليب مواجهة الضغوط وعلاقتها بكـل

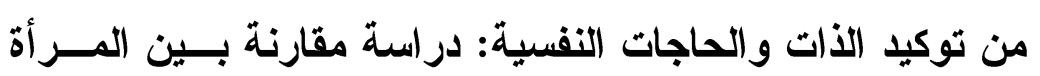

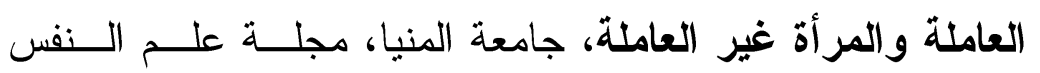
المعاصر و العلوم الإنسانية، الجزء الثاني، العدد الرابع عشر، ص

$$
\text { L.r-rAV ص }
$$

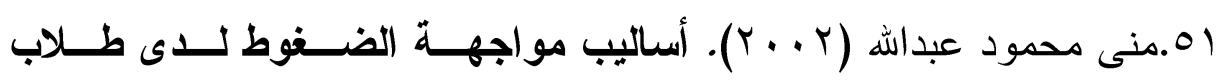

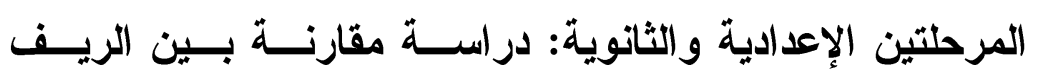

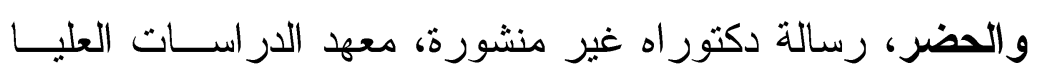

$$
\text { للطفولة، جامعة عين شمس. }
$$

ror.مني الحديدي (7997) (99): رعاية وتأهيل المكفوفين. سلســلة الاراســات الاجتماعية، القاهرة: مطبوعات جامعة الدول العربية. سه.ناصر علي الموسوي (1990) : المنهج الإضــافي ودوره فـي تنميــة

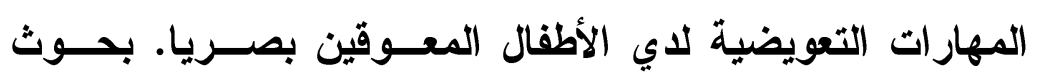
ودراسات في التربية الخاصة (المحتوي والتعليمـات) المــؤتمر القومي الأول للتربية الخاصة في مصسر، وزارة التربية و التعليم،

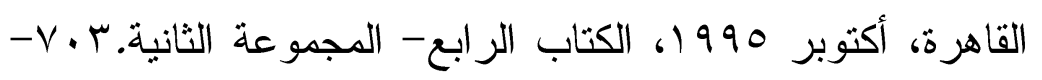
VY人

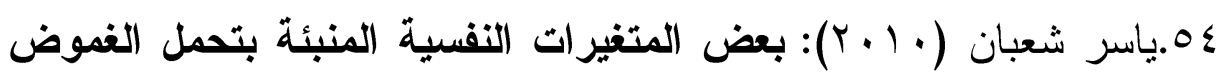

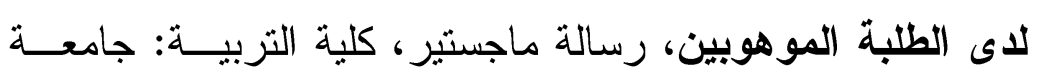

$$
\text { الفيوم. }
$$




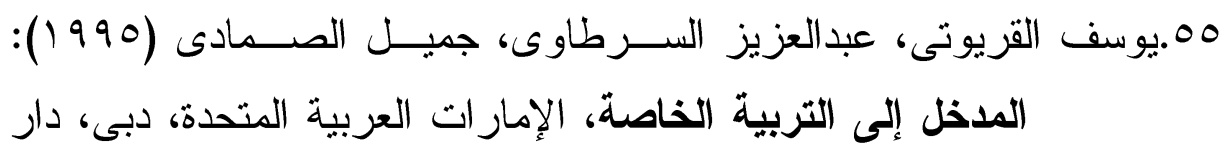

القلم.

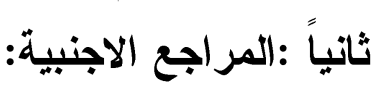

56. Bartone , P. (2008): Hardiness and resilience, www.hardinessandresilience.com.

57. Beck, A. (1976). Cognitive therapy and emotional disorders. New York: International University Press.

58. Bessmer, J.L. (1996): Dyadic Parent, Child Interaction Coding System II (Dpiscii): Reliability and Validity. (Behavioral Coding System II (DPSIC 3 II): PhD. University of Florida.

59. Cohen, R. (1994). Psychology and Adjustment: Values, culture and change. Boston: Allen and Bacon.

60. Dewe, P. (2000). Coping, Health and Organizations. New York: Longman.

61. Dods , A. (1986) : Handicapping conditions in children , London ‘Bill Gillham 6

62. Feely, M. ; Vetere, A. \& Myers, B. (2007) : Qualitative Analysis of Reading Rehabilitation of Persons with Age-Related Macular Degeneration , Journal of Visual Impairment \& Blindness, 101 (1) 44-49

63. Florian, V. et al. (1995): Does hardiness contribute to mental health during a Stressful real life situation ? the role of personality and social psychology , 69 (4) 687-695.

64. Funk, S. (1992): Hardiness: A Review of theory and research, health psychology VOL. 11, No. 5, pp. 335 - 345.

65. Gresham,F. (1988): Self efficacy difference among mildly handicapped, gifted and non handicapped students. The Journal of special. Education, (18) PP,90-100.

66. Hallahan D., \& Kauffman , J. (1991) : exceptional children introduction to special education, Englewood clefts : prentice-hall, international inc., f. f. the dictation .

67. Haward, W \& Oriansky, M (1992) : Exceptional children, new York , publishing company .

68. Hydon, B. (1986): The pleasures of psychological hardiness, New York, New American Library.

69. Jackson, R. (1990): The Relationship Between Family Environment and Psychological Distress in Visually Impaired Adults, Dissertation, United States, California, P. 144.

70. Johnson, M. (2004): Hardiness skills for girls , institute for girls development , a psychological corporation , 1-4.

71. Kennedy, M. (1997): Drawing and the Blind pictures to touch, Yale university Press, Toronto .

72. Kobassa , S. (1979): How much stress can you survive? American health , 3 , Inc. 
73. Kobasa, S, (1982): Commitment and coping in stress resistance among lawyers, journal of personality and social psychology, VOL. 42, No. 4, pp. $707-717$.

74. Kobasa, S. (1983): How much stress can you survive? American health, 3, Inc.

75. Kobasa, S. ; Maddi , D. \& Pucceti, M. (1983): Personality and social resources in stress resistance, journal of personality and social psychology, VOL. 45, No. 4, pp 839 - 880.

76. Kobasa, S, Maddi S. R., Paccetti, M.C \& Zola, M.A., (1985): Effectiveness of hardiness, exercise and social support as resources against illness, journal of psychosomatic research, No. 29, pp 525 - 533.

77. Lazarus, R. \& Folkman, S. (1984). Stress, appraisal and coping. New York: Springer Publishing Company.

78. Leyser, y-et al. (1996): Stress and Adaptation in Families of Children with Visual Disabilities- Families in Society, Apr., Vol77 (4): 240-249.

79. Long, B. \& Cox, R. (2000). Women's ways of coping with employment stress: A feminist contextual analysis, In: P. Dewe Comping, Health and Organizations. New York: Longman, 109-121.

80. McDonald-L. (1996): Psychological Functioning of Adults with Visual Impairment: A Study of Assessment Methodology (Depression, SelfEsteem, Dependency, Anger). (PHD) St-Jon's-University New York, Diss. Abs. Int., Vol. (58) 2-B, p. 983.

81. Moor , E. (1991): Occupational Self-Efficacy, Caveer beliefs, and Self-Esteem of Visually Impaired Students. (PHD) Indian State University, Diss. Abs. Int. Vol. (54) 4-A p. 243.

82. O'Connell, M ; Lieberman, J\& Petersen, S (2006) : The Use of Tactile Modeling and Physical Guidance as Instructional Strategies in Physical Activity for Children Who Are Blind, Journal of Visual Impairment \& Blindness, 100 (8) 471-477.

83. Stolarski, V. (1991): Stress Levels Experienced by Family Members of Visually Impaired Children, Dissertation, United States, New York.

84. Sweet, L. et al., (1999). Appraisals, coping and stress in breast cancer screening: A longitudinal investigation of causal structure. Canadian Journal of Behavioural Science, 31(4): 240-253.

85. Taylor. B. (1995): An Analysis of A relaxation stress control program in an alternative elementary school, Dissertation Abstracts International, Vol. 35 - 50, pp 1402.

86. Trevethan, T.; Sahraie, A \& Weiskrantz, L (2007) : Can Blind sight Be Superior to Sighted-Sight, Cognition, 103 (3) 491-501.

87. Volenski, L.T. (1995): Building School Support Systems for Parents of handicapped Children: The Parent Education and Guidance Program, Psychology in the Schools, Apr, Vol. 32, (2): 124-129.

88. W.H.O (2012): Magnitude and cause of visual impairment. Research Tools, 14.

89. Wakefield, E.; Homewood, J \& Taylor, J. (2006) : Early Blindness May Be Associated with Changes in Performance on Verbal Fluency Tasks, Journal of Visual Impairment \& Blindness, 100 (5) 306-310.

90. White, E. (2000). Coping with stress: Are there differences between gender?. Journal of Psychology, 13, 1-4.

r. o 
صلابة الشخصية وعلاقتها بأساليب مواجهة الضغوط النفسية لاى المر اهقين المكفوفين د. سهام عبد الغفور

91. Wiebe, D. (1991): Hardiness and stress moderation: A test proposed mechanisms, Journal of personality and social psychology, Vol.60, No. 1, pp 89 - 99. 


\section{ملحق (أ)}

مقياس صلابة الثخصية لاى المكفوفين

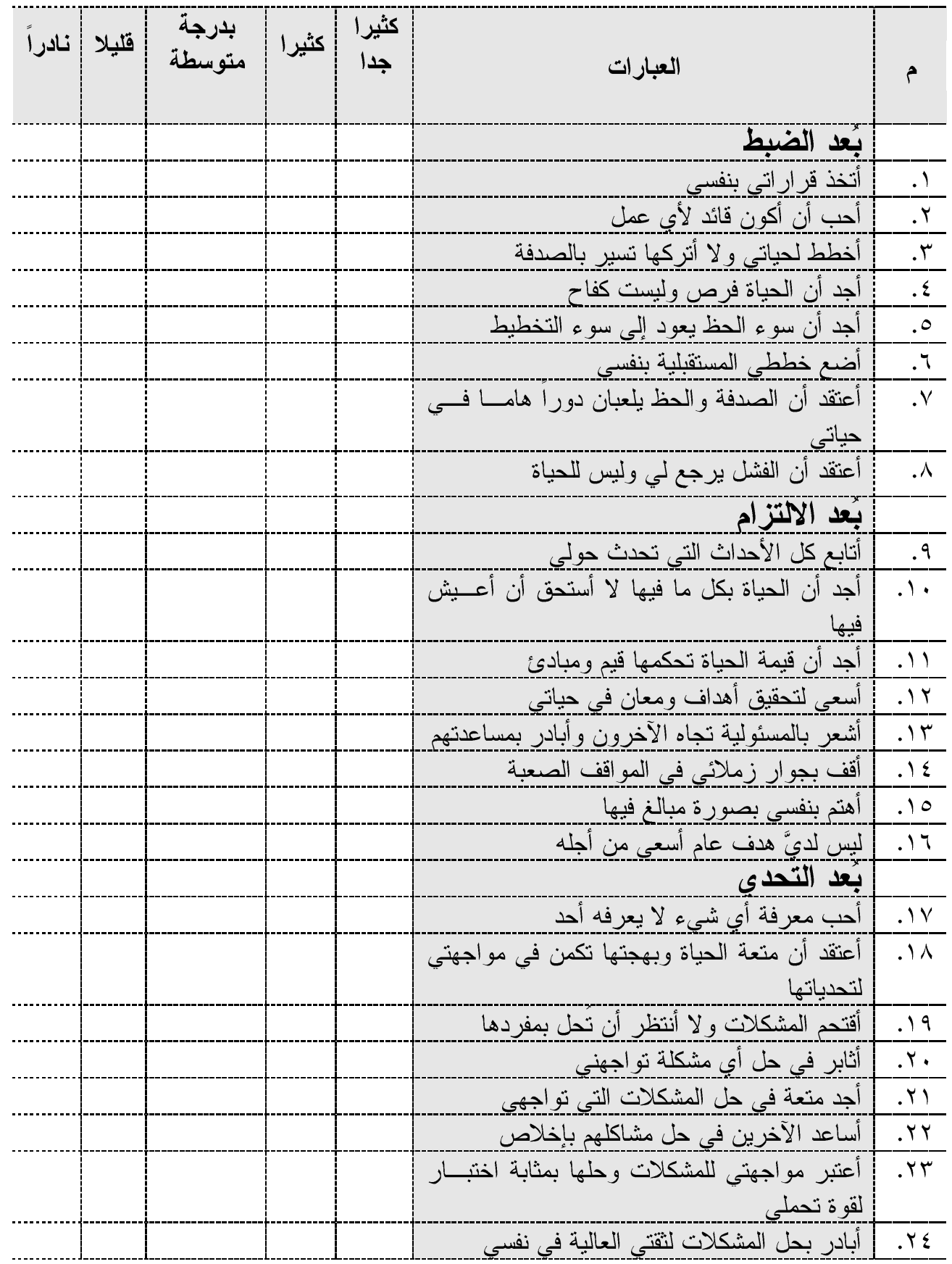

$r \cdot v$ 
صلابة الثخصية وعلافتها بأساليب مواجهة الضغوط النفسية لاى المراهقين المكفوفين د. سهام عبد الغفور

\begin{tabular}{|c|c|c|c|c|c|c|}
\hline نادراً & 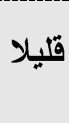 & متوسطة & كثيرا & كثيرا & 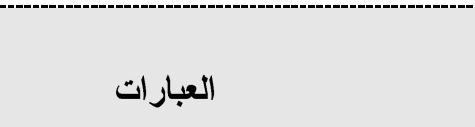 & r \\
\hline & & & & & بعد المرونة & \\
\hline & & & & & بمكني التي اصل بنجاح مع الآخرين & .ro \\
\hline & & & & & لا أتعثز عند مواجهة المشكلات &. $\mathrm{rT}$ \\
\hline & & & & & بمكنيي التأثثر في الآخريني &.$r V$ \\
\hline & & & & & اتحدي نفسي و اقبل نتيجة التحدي &.$r \Lambda$ \\
\hline & & & & & أتحكم في انفعالاتي_واوزيها & .49 \\
\hline & & & & & يمكني التعامل مع العاديين بنجاح & r. \\
\hline & & & & & أَقدر يَأي الآخرين في_و لا ابتعد عنمـ. & m \\
\hline & & & & & أققدر أنتو افقي مع مشكلاتي الصعبة & r \\
\hline
\end{tabular}




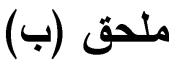

\section{مقياس أساليب مواجهة الضغوط النفسية}

\begin{tabular}{|c|c|c|c|c|c|c|}
\hline هوأفسق & 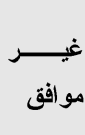 & إلسا ما & هو افق & هدأ & العبارات & \\
\hline & & & & & أنظر إلى من هم أكثر مني معاناة & 1 \\
\hline & & & & & أسأل الله العون في أن يخفف عنى عبء كف البصر & r \\
\hline & & & & & أبحث عن الجو انب الإيجابية في شخصيني & r \\
\hline & & & & & أتخيل هبوط حلول سحرية لمشكلتي & $\varepsilon$ \\
\hline & & & & & أثشعر بأنني السبب في اعتمادي على الآخرين & $\circ$ \\
\hline & & & & & أحكي معاناتي إلى أي شخص أقابله & T \\
\hline & & & & & أطارد أو هامي المرتبطة بالتفاؤل و الأمل & $\mathrm{r}$ \\
\hline & & & & & استعين بذوي الخبرة في حل مشكلاتي & $\wedge$ \\
\hline & & & & & أبحث عن حل لمشكلاتي لكي أؤكد قدراتي & 9 \\
\hline & & & & & أحلم بعالم خال من الكره ووصم المعاقين & 1. \\
\hline & & & & & أشعر بالندم على عدم رعاية نفسي & 11 \\
\hline & & & & & أفرط في تناول الطعام عند تذكري كف بصري & ir \\
\hline & & & & & أحاول ممارسة أية هو اية تجنبا في التفكير في إعاقتي & ir \\
\hline & & & & & أثنعر بالفرح عندما يبادر أحد في مساعدتي & $1 \varepsilon$ \\
\hline & & & & & لاي القدرة على مو اجهة مشكلات المدرسة & 10 \\
\hline & & & & & أود أن نحل مشكلاتي دون تحمل أي مسئوليات & 17 \\
\hline & & & & & أعتقد أنني المسئولة الوحيدة عن ضعفي & iv \\
\hline & & & & & إعاقتي اللوم على والدي باستمرار لأنه المسئول عـن & 11 \\
\hline & & & & & أحاول الاستغراق في العمل الذي بعطيني الأمل في & 19 \\
\hline & & & & & | النسيان & \\
\hline & & & & & | أناقش المشكلات بموضوعية مع من أثق فيهم & r. \\
\hline & & & & & أحاول استثمار الجوانب الإيجابية في شخصيتي & r) \\
\hline & & & & & أتخيل باستمر ار إنه بمكن شفائي من كف البصر & rr \\
\hline & & & & & | يغضب مني البعض عند محاولة حل مشكلاتي & r \\
\hline
\end{tabular}

$r \cdot q$ 
صلابة الثخصية وعلافتها بأساليب مواجهة الضغوط النفسية لدى المر اهقين المكفوفين ـ. سهام عبد الغفور

\begin{tabular}{|c|c|c|c|c|c|c|}
\hline \multirow{2}{*}{ 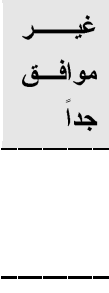 } & \multirow[t]{2}{*}{ 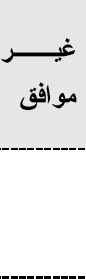 } & \multirow[t]{2}{*}{ حـ ما } & \multirow[t]{2}{*}{ 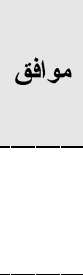 } & \multirow[t]{2}{*}{ هـاً } & \multicolumn{2}{|l|}{ 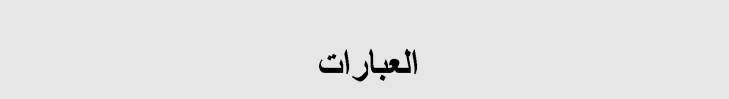 } \\
\hline & & & & & أحاول الهروب من التفكير في تصرفات الآخــرين & $r \varepsilon$ \\
\hline & & & & & أحاول قضاء وقت طيب مع أفر اد أســرتي بغـض إعض & ro \\
\hline & & & & & أشتعر بالخجل أو التردد عند طلب المساعدة من احد & ry \\
\hline & & & & & أثشعر بالضياع عند محاولة حل مشكلات صعبة & rv \\
\hline & & & & & تر اودني فكرة حدوث معزة من أجل شفائي & rA \\
\hline & & & & & مشكلاتي ينتي الخوف عند شــعوري بــالعجز فــي حـل & rq \\
\hline & & & & & أبكي و أصر خ عند فشلي في حل مشكلاتي & $r$ \\
\hline & & & & & أنعلم أساليب الاسترخاء حينما نو اجهني أية مشكلة & m \\
\hline & & & & & أطلب دعاء الآخرين لتخفيف معاناتي من مشكلاتي & ru \\
\hline & & & & & أقابل ذوب الخبرة لمناقشة مشكلاتي & r \\
\hline & & & & & واجباتير عليّ أحسـلام اليقظــة، وتعطلنــي عــن أداء & $r \varepsilon$ \\
\hline & & & & & أُشعر بالعجز لعدم قدرتي على التكيف مع نفسي & ro \\
\hline & & & & & 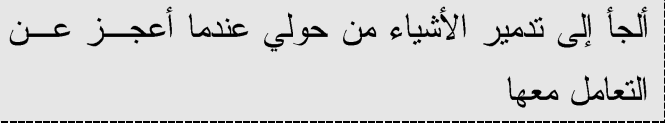 & דו \\
\hline & & & & & ألجأ إلىى اله من أجل تخفيف معاناتي & rV \\
\hline & & & & & أحب حضور حصصي الدر اسية & rᄉ \\
\hline & & & & & أرى أن مشكلتي ساعدنتي على اكتثــاف الأثــياء & rq \\
\hline & & & & & أتصور أن المشكلات يمكن أن تحل بالحظ & $\varepsilon \cdot$ \\
\hline & & & & & أثشعر بالندم عند ضياع أية فرصة لاكتساب مهــارة & « \\
\hline & & & & & أصبح عنيف مع المحيطين بي لعدم تقدير حالتي & $\varepsilon r$ \\
\hline
\end{tabular}

